STUDENTS' CHOICE OF A BUSINESS MAJOR AND CAREER:

A QUALITATIVE CASE STUDY OF MOTIVATION TO STUDY

FINANCE AND BANKING

\author{
by \\ SOKALYAN MAO
}

\begin{abstract}
A thesis
submitted to Victoria University of Wellington

in fulfillment of the requirements for the degree of

Master of Education
\end{abstract}

Victoria University of Wellington

2013 


\begin{abstract}
Little is known about how or why Cambodian university students choose a major and a future career. The decision regarding a major is important for a student's life and future career. The Cambodian labour market has a shortage of graduates in science, technology, engineering, maths and agriculture and a predicted oversupply of business graduates. In recognition of the mismatch between the supply of business graduates and the demands of the labour market, the current study was designed to explore why and how Cambodian students choose a business major and a future career.

This qualitative study employed a multiple case study design. The study utilized semistructured interviews to collect data from five male and five female students enrolled in finance and banking majors, who volunteered to participate in the research. Data analysis was mainly inductive with consideration given to the expectancy-value theory (Eccles, 2009) using a within-case and cross-case analysis within a thematic approach.

The findings were that value beliefs were important in students' choice of a major. Students chose a finance and banking major because they believed that this major would have good employment prospects and lead to a worthwhile career. Other reasons included the interest value related to the subject and to a career, their beliefs in their ability to earn a business degree, and usefulness to the long-term plans of business ownership. In some cases, students chose the business major over a preferred major for diverse reasons including: not wanting to move away from family; a family's desire to provide security for female offspring; the prohibitive costs of the preferred major; and doubts about their ability to succeed in the preferred major. The extended family was influential in decisions around choice of major and career. Participants listened to the advice of older siblings. The financial support of parents was also pivotal. Farmers did not want their children to work in agriculture and saw business as offering a better life.
\end{abstract}




\section{Acknowledgements}

This thesis is dedicated to the Cambodian Ministry of Education, Youth and Sports and my scholarship donor: the New Zealand Aid Programme. Without this scholarship, I would not have been able to begin my academic life at Victoria University of Wellington. Its final completion is due to some key people and I would like to take this opportunity to express my gratitude for their support and encouragement. I would like to thank a number of people:

Dr Stephanie Doyle for her superb supervision, kindness and ongoing support. Your belief and encouragement have stimulated me to successfully complete this project. You will be a role model for my future career once I return to work in Cambodia. Thank you so much.

My cohort group members: Alana Moriarity, Liz Chinlund, and Vu Thuong Ha for being my critical friends from the beginning of this current study.

Elizabeth O'Connor, Student Learning Support adviser, for her support in improving the quality of the thesis. Dr Lottie Thomson, Mabel Hamon and Dr Geoff Plimmer for their guidance, advice and willingness to share experience.

Especially my loving husband, Sam Oll, for your eternal love, support and beliefs in me. Thank you for your patience in listening to me despite your tiring work. I love you.

My family and friends for their love and encouragement. Knowing that you were waiting for my return to Cambodia stimulated me to work faster.

Many thanks to the rector and staff of the University of Battambang in arranging a research data collection. Thanks to the student participants who generously chose to be involved in this project, without you this research would not have been possible. 


\section{Table of Contents}

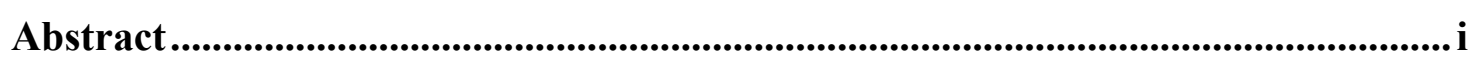

Acknowledgements......................................................................................... ii

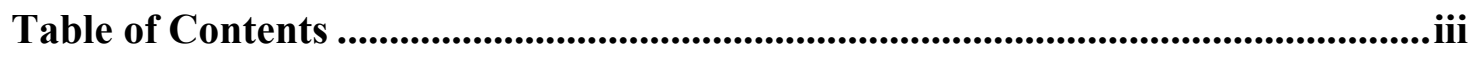

Table of Figures............................................................................................................................... vi

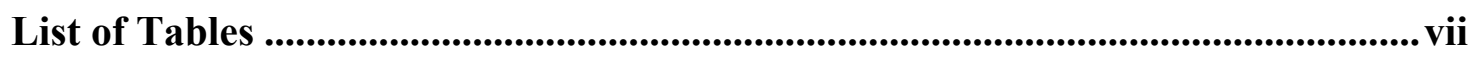

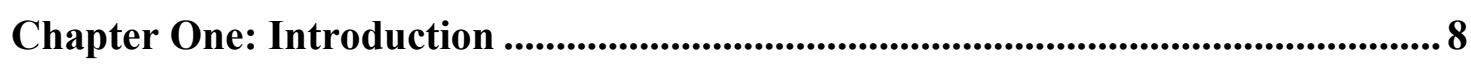

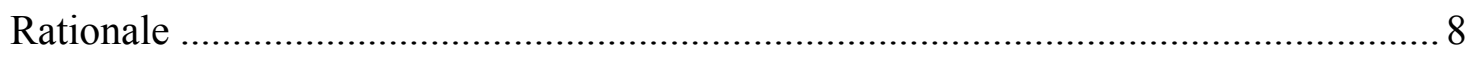

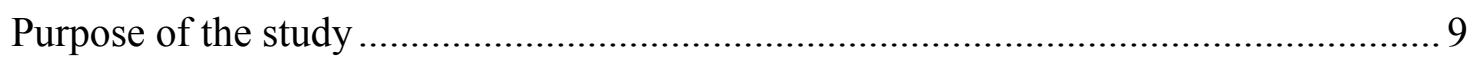

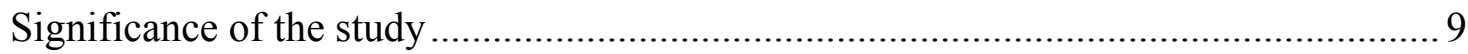

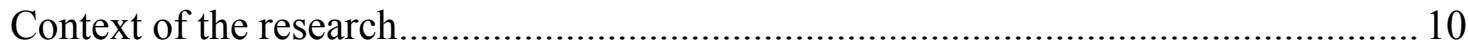

Chapter Two: Literature review............................................................................................. 15

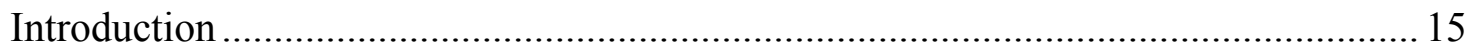

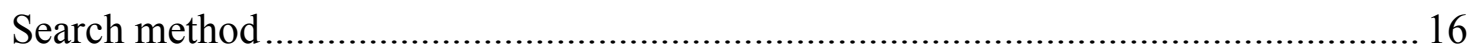

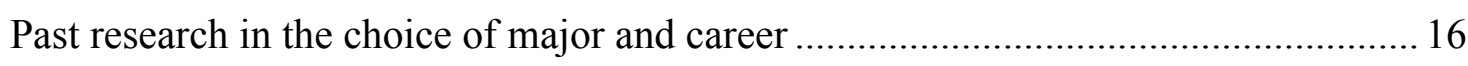

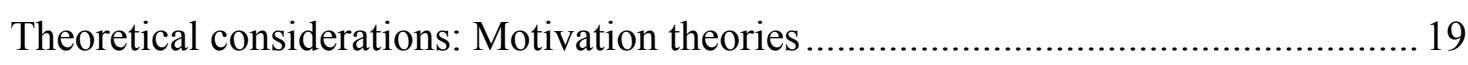

Social cognitive theory of self-efficacy ……................................................. 19

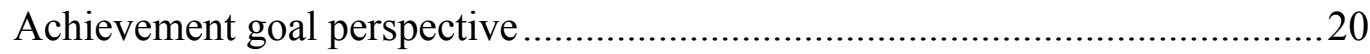

Social Cognitive Career Theory (SCCT) ........................................................22

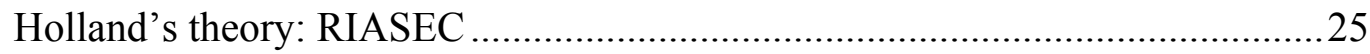

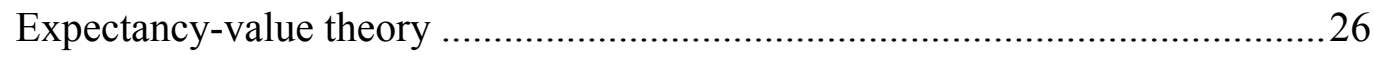

Choosing a major or career as a complex decision-making process ........................... 30

Major choice: Decision-making model ....................................................... 31

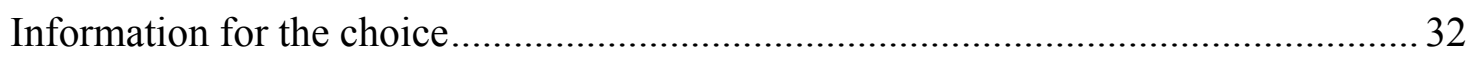

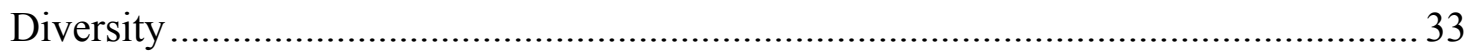

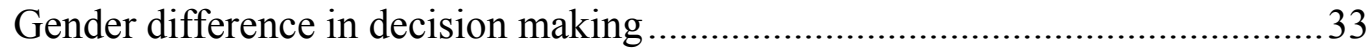

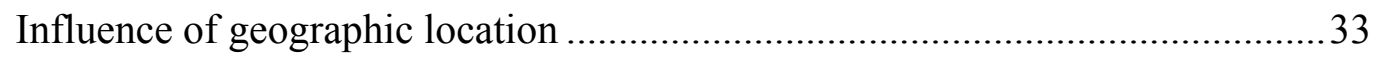

Cultural influences on motivation and choice of major ......................................... 33

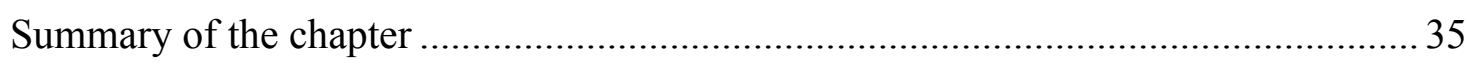

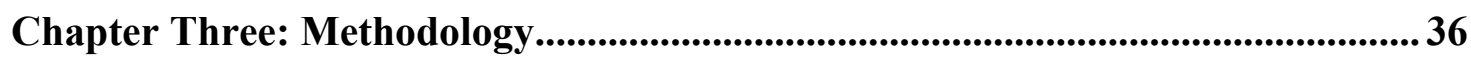

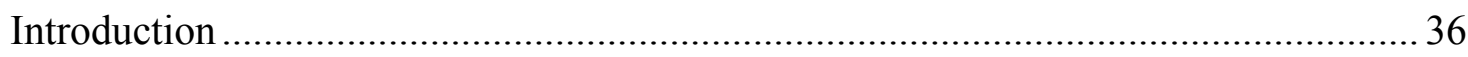

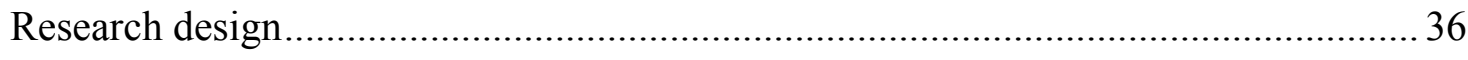


Setting

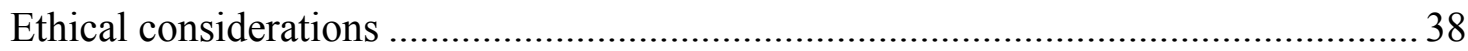

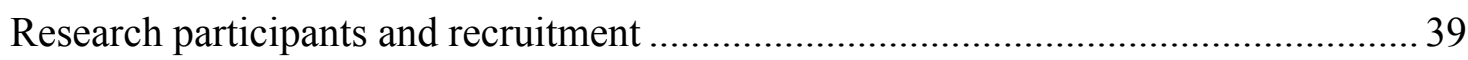

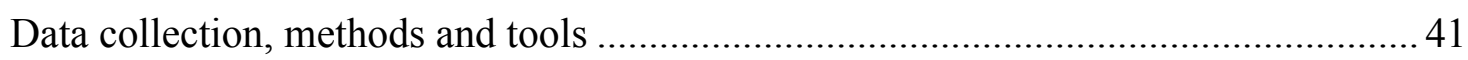

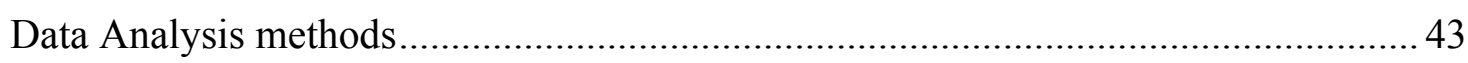

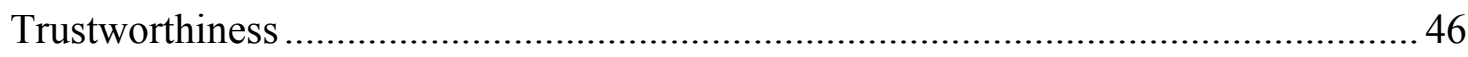

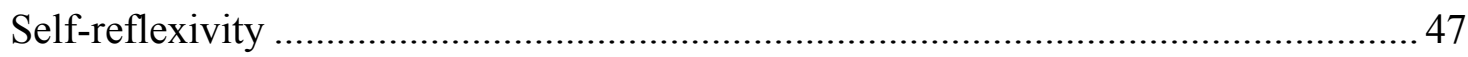

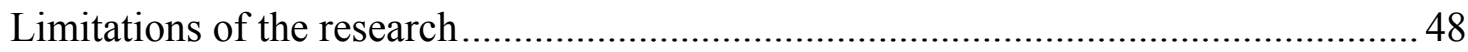

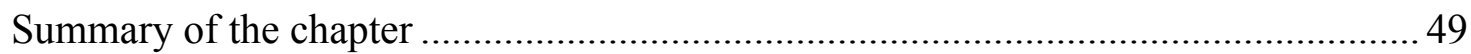

Chapter Four: Findings and descriptions of individual cases ............................50

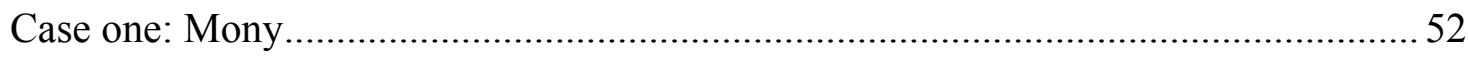

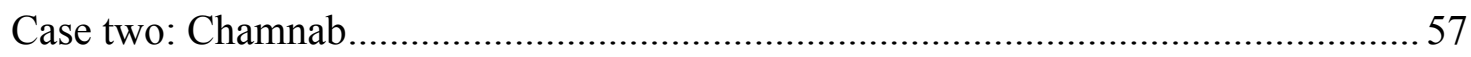

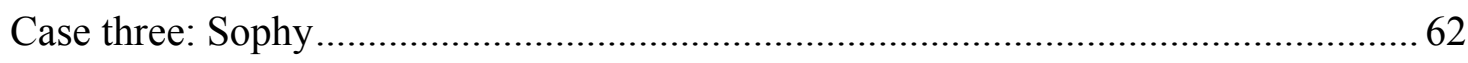

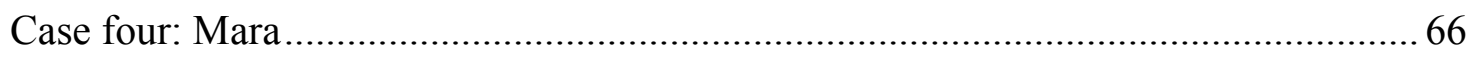

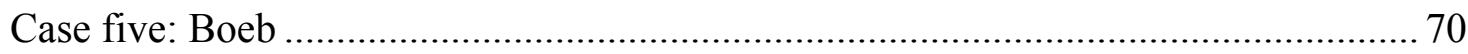

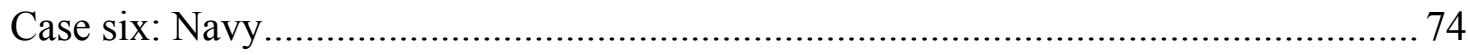

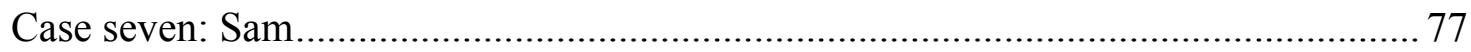

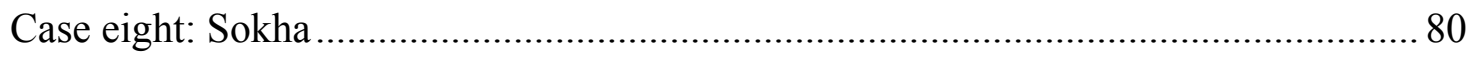

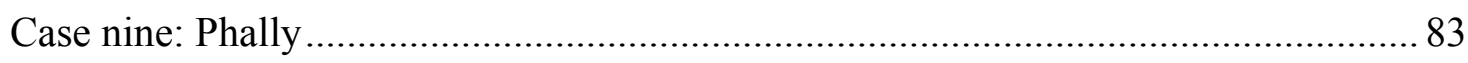

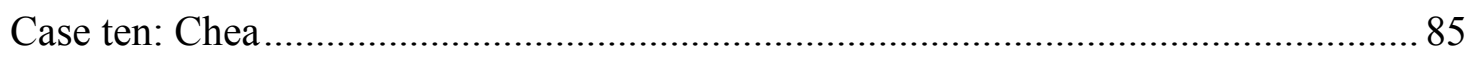

Chapter Five: Findings from cross-case analysis .................................................. 90

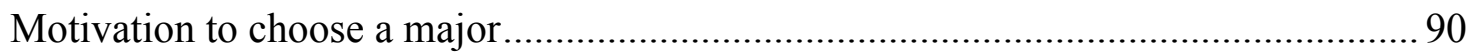

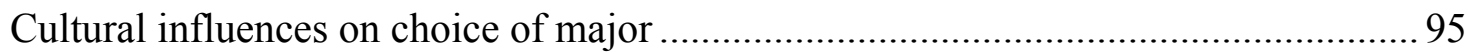

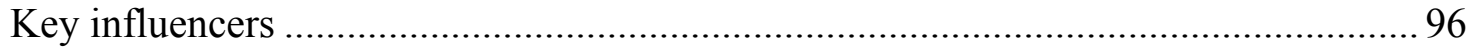

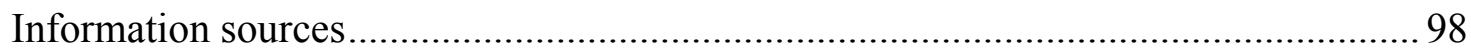

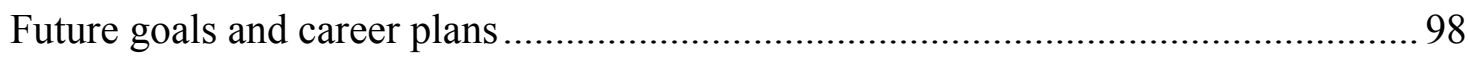

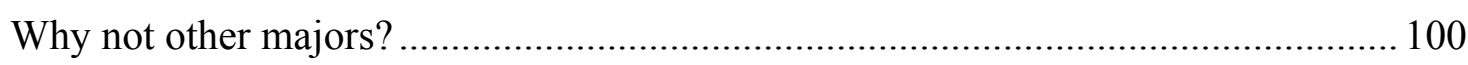

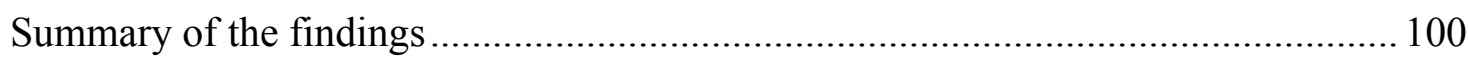

Chapter Six: Discussion and conclusion ..........................................................103

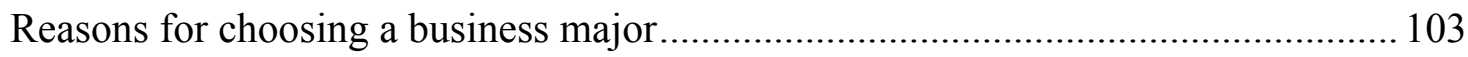

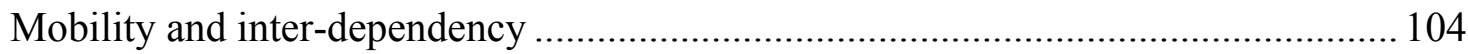

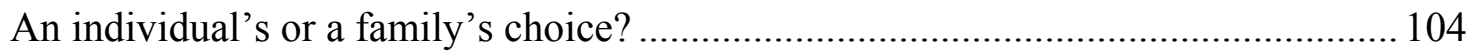

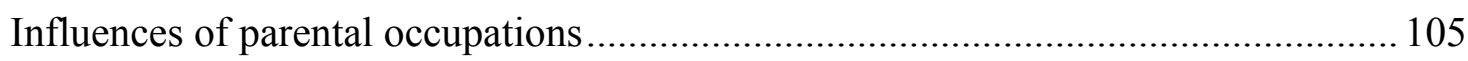




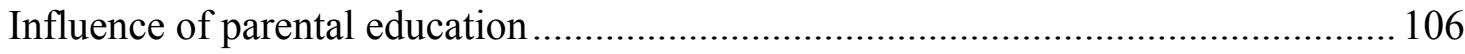

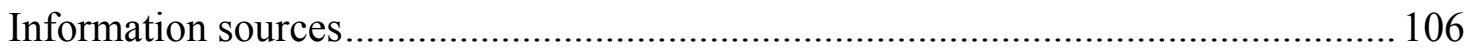

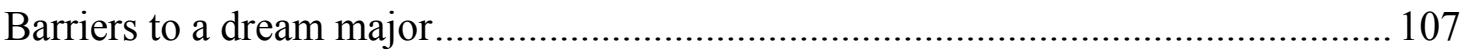

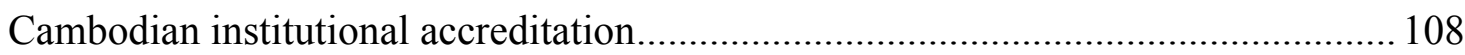

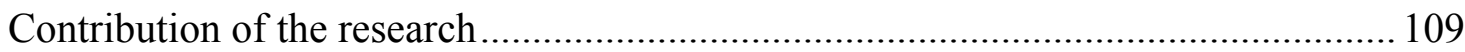

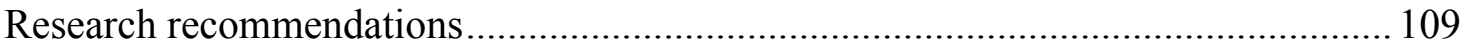

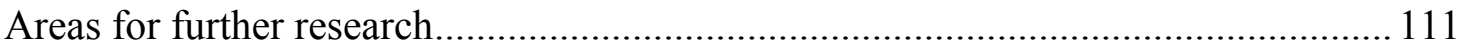

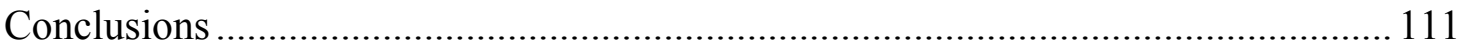

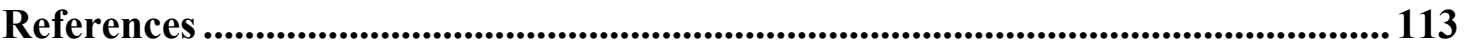

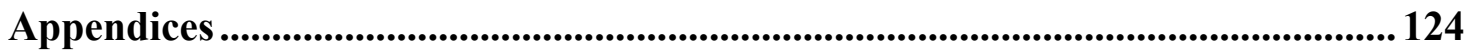

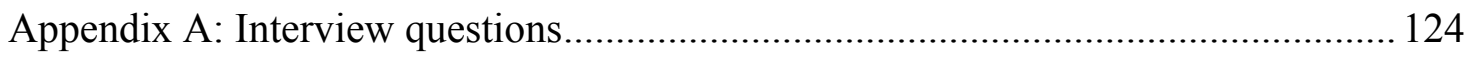

Appendix B: Brief biographies of research participants ....................................... 125

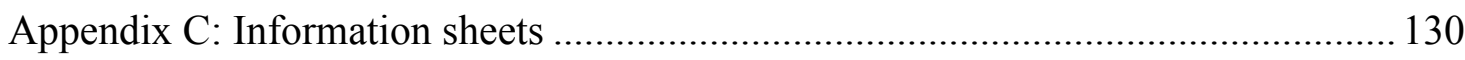

Appendix D: Consent forms of the research ........................................................... 139 


\section{Table of Figures}

Figure 2.1. The relationship between expectancy and value beliefs and the motivated action to earn a business degree .......................................... 28

Figure 2.2. Working model for decision-making process.................................... 32

Figure 3.1. The process of cross-language interpretation ................................... 45

Figure 4.1. Factors that influenced Mony's choice of major .................................56

Figure 4.2. Factors that influenced Chamnab's choice of major ........................... 61

Figure 4.3. Factors that influenced Sophy's choice of major ...................................65

Figure 4.4. Factors that influenced Mara's choice of major ..................................69

Figure 4.5. Factors that influenced Boeb's choice of major ................................ 73

Figure 4.6. Factors that influenced Navy's choice of major ................................ 76

Figure 4.7. Factors that influenced Sam's choice of major .................................. 79

Figure 4.8. Factors that influenced Sokha's choice of major .............................. 82

Figure 4.9. Factors that influenced Phally's choice of major ................................. 85

Figure 4.10. Factors that influenced Chea's choice of major ................................ 89

Figure 5.1. A common pattern of participants' future career plans ....................... 99 


\section{List of Tables}

Table 3.1. Participants' demographic information.

Table 4.1. Definitions and example of final codes in the current study 51 


\section{Chapter One: Introduction}

\section{Rationale}

The choice of a university major is one of the most important decisions students make as it could influence their future career (Dawson-Threat \& Huba, 1996; Montmarquette, Cannings, \& Mahseredjian, 2001).Students' choice of a major is influenced by many factors (Montmarquette et al., 2001; Porter \& Umbach, 2006). A wide range of research has shown that many students choose to major in business primarily for job opportunities and the monetary rewards of these careers (Dudley, Dudley, Clark, \& Payne, 1995; D. Kim, Markham, \& Cangelosi, 2002; Mauldin, Crain, \& Mounce, 2000; Montmarquette et al., 2001).

Cambodia is a developing country in Southeast Asia. Its estimated population in 2011 was 14,521,275, of which 51\% were female (Ministry of Planning, 2008). The garment, tourism, and construction sectors have been major contributors to economic growth and employment in Cambodia (Economic Institute of Cambodia, 2008). However, the sustainability of these sectors is a concern as growth is expected to slow or may remain flat in the coming years. It should be noted that the majority of Cambodians rely on the agricultural sector for their livelihoods. Unfortunately, this sector remains poor and unstable (Economic Institute of Cambodia, 2008).

The current enrolment rates in Cambodian tertiary education are about one third of those in other developing countries in the region such as Thailand and Laos (World Bank, 2012). Five percent of the tertiary age group is pursuing higher education, of which 7\% are male and 5\% are female (World Bank, 2012). The unemployment rate of graduates with bachelor degrees under 29 years of age is $5 \%$ while $10 \%$ of graduates reported an "unpaid" employment status(National Institute of Statistics, 2009).

The Ministry of Education, Youth and Sports (MoEYS), employers and recruitment agents argue that Cambodia is producing too many business graduates including accounting, finance, and management (almost half of all bachelor students in 2009 $10)$, compared to civil engineering ( $1.5 \%$ of all students), and science and technology ( $0.1 \%$ of students) (Cambodian Federation of Employers and Business Associations, 2008; MoEYS, 2009; World Bank, 2012). Only 2.3\% of graduate students study 
disciplines related to agriculture and the off-farm rural economy, which are Cambodia's key industries and are in need of upgrading (World Bank, 2012). This suggests a mismatch between higher education provision and labour force needs (Chet, 2006; Ford, 2006; Innes-Brown, 2006; Sloper, 1999; World Bank, 2010, 2012).

As mentioned above, while there is a shortage of higher education graduates in engineering and sciences, Cambodia will see an oversupply of graduates in business. Therefore, it is interesting to explore why and how these students decide to pursue business despite the high level of competition in the business labour sector.

\section{Purpose of the study}

The purpose of this study was to:

(1) understand how and why students choose to major in a business degree

(2) explore factors that influence students' future career plans.

Given this purpose, the study seeks to answer the following research questions:

(1) how do students' beliefs contribute to their choice of major in their degree?

(2) what influences students' future career plans?

\section{Significance of the study}

Research on students' choice of major has been undertaken in various disciplines, for example engineering (Matusovich, Streveler, \& Miller, 2010), information technology (Mclnerney, Didonato, Giagnacova, \& O'Donnell, 2006) and agriculture (Wildman \& Torres, 2001). However, this research study will focus on the under-researched area of business. Internationally there is growing interest in students' decision making (Galotti, 1999; Leach \& Zepke, 2005). It should be noted that there has been little Cambodian based research, especially on Cambodian higher education (MoEYS, 2009). Therefore, this research is highly relevant and its findings can inform relevant stakeholders on the research topic. 
A deeper understanding of how students select and value a business major can reveal values students set for their study and their future career prospects related to their interests, perceived costs, attainment, and utility. Understanding students' values can help educational stakeholders to support and provide appropriate guidance to students and their parents regarding the labour market. Examples of educational stakeholders include lecturers, career advisors, administrators, faculties, and public policy makers. In addition, an increased understanding of students' values and career plans can improve or create more supportive services and programmes from the stakeholders. Understanding students' goals, objectives and values is significant for stakeholders and educators involved in recruiting and training students.

\section{Context of the research}

\section{Cambodian Higher Education System}

Cambodian higher education is comprised of two interrelated streams: academic and vocational. Different government ministries oversee each stream. The MoEYS is responsible for the academic stream whereas the vocational stream is under the supervision of the Ministry of Labour and Vocational Training. In addition to the management and supervision from the two lead ministries, numerous specialized ministries play important roles in the provision of higher education services(Chet, 2006).

Cambodian higher education institutions (HEIs) have three categories: the academy, the university, and an institute or independent school for students who have successfully completed Grade 12 in upper secondary school or an associate degree (Chet, 2006). An academy offers advanced degree programmes from masters to doctoral degrees. A university has at least four faculties offering bachelor degrees and higher degrees. In contrast, an institute or independent school mainly offers training in a particular field, but not a wide range of research or training in multi-disciplinary subjects(MoEYS, 2011).

\section{Quality and accreditation of higher education in Cambodia}

An increasing number of youth are coming out of school with dreams of obtaining degrees from universities and prosperous jobs to build their future(World Bank, 2012).Therefore, accreditation is increasingly important for young people and their 
parents to ensure the government endorses the quality of the institution they have chosen to study at(Chet, 2006). The quality of higher education is a sensitive topic. The public and educational critics have doubts about the success and future of Cambodian higher education (Chet, 2006; Ford, 2006). The MoEYS has admitted that quality assurance in higher education is a major challenge (MoEYS, 2009). In order to address this issue, the Accreditation Committee of Cambodia (ACC) was established in 2003. The ACC developed nine institutional accreditation standards. One standard is to develop the knowledge, competence and skills of students and to prepare them for making a career choice. Therefore, it is important for the ACC to ensure that HEIs provide quality education and guidance for students in choosing a major and career.

\section{Aims of education in Cambodian educational policies}

Due to the influence of major international donors including the World Bank and the International Monetary Fund (IMF), the purpose of education in Cambodia is solely economic rather than social. Education has been defined to be about skill attainment where the most valued skills are those that translate to employability (Crowley, 2010).

On the other hand, it is interesting to note that the Cambodian government has a much more holistic understanding of the broader purposes of education. This is despite its adoption of the business language of education reform, which emphasizes the economic purposes of education. For example, in the National Strategic Development Plan (MoEYS, 2005), the role of MoEYS is to continue to provide and expand access to higher education while at the same time safeguarding quality. It gives priority to students enrolling for "less market-oriented and more socially beneficial programmes" (p. 8), which it believes to be in education, health, agriculture, science and mathematics.

To sum up, the main purpose of Cambodian higher education is to encourage students to enrol in programmes such as Science, Technology, Engineering and Mathematics (STEM), health, education and agriculture as they are more socially beneficial. Even though these programmes are prioritized, the number of students enrolled in the programmes has been very low. A remarkable number of students (almost half of the total number of bachelor students) have enrolled in business-related programmes, which have been reported to have an oversupply of graduates (Cambodian Federation of Employers and Business Associations, 2008; HRINC, 2010; World Bank, 2012). 


\section{Supply of Cambodian higher education programmes or majors}

The curriculum development policy states that when students leave school they should have developed a love of learning that will allow them to pursue employment(MoEYS, 2004). However, it should be noted that the aim of this curriculum tends to be more for culture, intellectual development and morality. According to the Policy for Curriculum Development (MoEYS, 2004), the aim of the curriculum is to fully develop "the talents and capacities of all students in order that they become able people, with parallel and balanced intellectual, spiritual, mental and physical growth and development" (MoEYS, 2004, p. 1).

A wide range of reports and research have identified that the focus of higher education institutions in Cambodia has been on delivering inexpensive programmes rather than those such as science and engineering that are more costly to run (Chet, 2006; Ford, 2006; Innes-Brown, 2006; MoEYS, 2009). Less costly programmes are considered to be business, law and management (Ford, 2006; Odin \& Manicas, 2004). Besides the cost criteria for programme development, the curricula and the programmes tend to focus on short-term market needs (Chet, 2006). However, there is no reliable source of market needs. Links with the employment market or private sector in building curricula are the responsibility of the university. Universities may have key informants or advisors to help them; however, little or no guidance is provided from the department of higher education itself (Chet, 2006; Innes-Brown, 2006). Without a labour market information system, which can inform universities proactively as to future skill needs, development and implementation of programmes is often reactive, addressing the needs of the market as they arise (Innes-Brown, 2006).

\section{Unemployment and mismatch between demand and supply of the chosen majors or skills in the labour market}

The Prime Minister of Cambodia in a speech to the Cambodia-Korea Business Luncheon in 2006 highlighted Cambodia's economic growth:

Our economy is still in good shape by having achieved a decade of sustainable strong economic growth and sound macro-economic management. A recent World Bank's study placed Cambodia in the top ten developing countries with the highest economic growth rate from 1998-2007. 
The Cambodian economy has been growing since it was a member of Association of South-East Asian Nations (ASEAN) and the World Trade Organization (WTO). Despite the growth in the economy, unemployment among Cambodian youth remains high. Cambodian Federation of Employers and Business Associations (2008)estimate that the supply of university graduates between 2009-2014 is likely to exceed the number of available jobs for these graduates. In other words, the Cambodian economy is unlikely to be able to absorb all the students who will complete their university degrees over this period. A study conducted by the Cambodian Federation of Employers and Business Associations (2008) found that more than half of Cambodia's total unemployed were under the age of 25. This age represents youth and many of them are bachelor graduates. Previous research has indicated that unemployed graduates were more likely to be from private HEIs than from public universities (Ford, 2006). Ford reported that $30 \%$ of graduates from public universities were unemployed one year after graduating while this figure leaped to $90 \%$ of graduates from private universities. Ford further claims that many graduates only get employment in fields unrelated to their study, indicating a mismatch between higher education provision and labour force needs.

In 2006-2007, more than 40\% of bachelor degree students were in business programmes(MoEYS, 2009). Many employers and recruitment agents argue that Cambodia seems to be producing too many business graduates and too few engineering and other technical graduates (Cambodian Federation of Employers and Business Associations, 2008). Because private HEIs are profit-seeking, the majority of them only offer courses with high demand and low costs, the most common of which are related to business administration and information technology (Ford, 2006; MoEYS, 2009).

The MoEYS recognizes the issue and problems of a substantial increase in the number of HEIs and that most HEIs are offering the same degree programmes. These areas of employment are already fully saturated while science, technology, mathematics, agriculture and health are areas of national need with insufficient numbers of students and graduates (MoEYS, 2009). In addition, employers assert that many business graduates lack the skills that they need including analytical and decision-making skills 
(Cambodian Federation of Employers and Business Associations, 2008). This raises more concerns about the curriculum, teaching and learning to develop appropriate skills.

Overall, while some studies show that there will not be enough jobs to absorb a large number of graduates (HRINC, 2010; World Bank, 2010), employers argue that graduates do not have the required skills to fulfill positions in their firms (HRINC, 2010). It is reported that there will be too many graduates specifically in businessrelated majors competing for too few jobs. The trends of the short-term market encourage students to choose inappropriate study disciplines and even within study disciplines, graduating students do not have the right skills for the labour market (World Bank, 2010). 


\section{Chapter Two: Literature review}

\section{Introduction}

The choice of major has been described as the most "thought-provoking, gut wrenching and rest-of-your-life oriented or disoriented" decision (St. John, 2000, p. 22). This choice is considered as a major life decision due to its impact on an individual's future career (Carnevale, Cheah, \& Strohl, 2011). The literature on choice of major is predominantly focused on the North American experience and while there are likely to be similarities with other parts of the world, as indicated in chapter one, the questions of choice of majors and careers are important in Cambodia and many other countries.

In chapter one, Cambodia's oversupply of business graduates was highlighted (World Bank, 2012). It appears that Cambodian students are strongly motivated to choose a business major despite a current and predicted future oversupply of graduates in business including accounting, finance and management (MoEYS, 2009; World Bank, 2010, 2012).

In order to have a better understanding of factors in students' motivation to choose a business major and career, the literature review will look at past research in this area to identify what has been found to be significant in influencing decision making. Expectancy-value theory was applied in this study and the review will provide a justification for choosing this theory over the other possible motivational theories in this review. The review will discuss a model of the decision-making process to understand the process students use in their choice of major. Although many of the theories, and past research are situated in Western settings, given that the current study is set in Cambodia, cultural context will be discussed throughout this review.

The main purpose of this literature review is to understand (1) what has been done in the area of motivation in the choice of business major and careers, (2) the main ways of theorizing or conceptualizing the motivation for choice of business major and careers, (3) the methods used in studying motivation for choice of business major and career, and (4) the gaps in the past research which led to the current study. 


\section{Search method}

The literature search for this review centred around motivation relevant to students' choice of a major and career. In order to identify reliable and relevant journal articles, sources and databases recommended by Victoria University of Wellington librarians including the Educational Resources Information Centre (ERIC), Pro Quest Education, Springer LINK Archive - CEIRC, and A+ Education were searched. Search terms were (1) major, field of study, degree, (2) higher education, postsecondary, tertiary, university, college, (3) career, job, occupation, profession, (4) decision making, (5) motivation, and (6) motivation theory. Also specific key terms such as Cambodia and business major were searched for more relevant information.

The inclusion criteria were that sources needed to be (a) peer-reviewed research that examined the choice of university major or career choice, and (b) scholarly books related to motivation theories. Reading the abstracts of searched articles and related documents helped eliminate a number of documents. The year of publication was not limited because I wanted to understand the development of research in the area of motivation and choice of business major and career over time. Some articles and scholarly books were excluded because they focused on the choice of higher education institutes or the plans of students at secondary schools (e.g. Berzin, 2010; Chenoweth \& Galliher, 2004; Mau \& Bikos, 2000; Tan, 2011).

\section{Past research in the choice of major and career}

There is a robust literature on the choice of major. However, there have been different foci in past research. Foci have included the determinants of a choice of major(D. Kim et al., 2002; U. Kim \& Park, 2006), parental influences on the choice of major(Brooks, 2004), the choice of major and the labour market(Brown, 2011; Chillas, 2009). The focus tends to slightly change during different periods of time. In the study of the choice of a university major, some researchers developed their own research tools for data collection drawing on specific motivation theories to describe how and why students made decisions in choosing a major(e.g.,Cebula \& Lopes, 1982).

In past years, a wide range of research in the area of choice of major has focused on the influence of the labour market on the choice of major (Chillas, 2009; Freeman, 1975; Ordovensky, 2004), and the relationship of relative rate of returns and the choice 
of major (Koch, 1972; Ordovensky, 2004). Some studies focused on determinants of the choice (Begg, Bantham, \& Taylor, 2008; Cebula \& Lopes, 1982; Koch, 1972; Swanson \& Tokar, 1991). For instance, Begg et al. (2008) investigated the students' psychological process in choosing a university major. They surveyed 4,817 students majoring in a public university in Midwest, US. Their analyses showed a match of interest and abilities with the students' first choice followed by a match with job characteristics and major attributes.

More recent studies have placed more attention on previously neglected areas such as individual interest and environment fit (Begg et al., 2008; Mclnerney et al., 2006; Porter \& Umbach, 2006), self-efficacy (Hughes, 2011; Lent, Brown, \& Hackett, 1996) and motivation and beliefs in the choice of a major (Jones, Paretti, Hein, \& Knott, 2010; Matusovich et al., 2010). For example Matusovich et al. (2010) used Eccles' expectancy-theory to explore how engineering students choose their university major. This longitudinal study was a multi-case study of eleven students in a technical school in the US. The study focused on subjective task values from Eccles' expectancy-theory to understand students' choice of major and their persistence to earn a degree in engineering.

Recent research has examined cultural influences in the choice of majors and careers (Creed \& Yin, 2006; Hughes, 2011; Mau, 2000; Song \& Glick, 2004; Weber, Ames, \& Blais, 2004). A number of studies focused on the relationship between self-efficacy and the academic or career achievements drawing on Bandura's social cognitive theory (Bandura, Barbaranelli, Vittorio, \& Pastorelli, 2001; U. Kim \& Park, 2006; Lent et al., 1996). Recent research in engineering has employed expectancy-value theory (Jones et al., 2010; Matusovich et al., 2010). The review did not identify any studies in the area of choice of a business major that utilized expectancy-value theory.

Studies in choice of business major have been conducted in different disciplines such as accounting (Cohen \& Hanno, 1993; Giladi, Amoo, \& Friedman, 2001; Mauldin et al., 2000), marketing (Lysonski \& Durvasula, 1998), information technology (Mclnerney et al., 2006) and across business disciplines (Begg et al., 2008; D. Kim et al., 2002; Malgwi, Howe, \& Burnaby, 2005). These studies have both common and diverse findings. One example of a common finding is expectations of job opportunities and high pay following graduation which have consistently been found to 
be significant reasons for choosing a major (Cebula \& Lopes, 1982; Dudley et al., 1995; Giladi et al., 2001; D. Kim et al., 2002; Malgwi et al., 2005; Swenson, Swinyard, Langrehr, \& Smith, 1993).

The reasons for students to choose a business major have been studied in prior research (D.Kim et al., 2002; Malgawi et al., 2005). D. Kim et al. (2002)investigated which factors were influential in students' choice of a business major, the extent to which the students were aware of relevance of the major to the business world, and how their understanding affected their career expectations. Their study surveyed 671 business students in 15 universities in the US. The top five reasons students provided for choosing the major were, in order of priority, interest in career related to the major, good employment opportunities, fit with own abilities, desire to run a business and projected earnings in the related career.

Malgwi et al. (2005)utilized a questionnaire to collect data from 788 undergraduate students at a large northeastern business school in the US. Malgwi et al. (2005)investigated factors influencing business students' choice of major. This study echoed the findings of Kim et al. (2002) that the main reasons for students to choose a major was their interest in the subject and the potential job opportunities.

There have been divergent findings on the influence of advisors such as parents, teachers and friends. For instance, in two studies (D. Kim et al., 2002; Malgwi et al., 2005)the influence from various advisors including parents, high school guidance counselors, and high school teachers/advisors was low. However, the influence of such advisors was found to be significant in other studies (Hughes, 2011; Lee \& Rojewski, 2012; Mau, 2000). The different findings as mentioned earlier may be due to the cultural contexts of the research. For example, Mau (2000) examined the cultural differences between 540 American students and 1026 Taiwanese students in two areas: career-decision making styles and self-efficacy. Mau highlighted culture as a main factor in decision-making styles, and he found that Taiwanese students' decision making was more dependent than American students. Taiwanese students sought approval from parents, elders and teachers before they made important decisions including career choice. Therefore, this suggests culture plays an important role in students' decision making. 
It is noteworthy that the majority of past studies in choice of business major are quantitative and typically use a survey framework. The questionnaires were often developed based on past studies and piloted before the survey (Cebula \& Lopes, 1982; D. Kim et al., 2002; Swanson \& Tokar, 1991). Few studies on the choice of a business major have employed qualitative methods such as in-depth interviews to understand students' motivation in choosing a major. In addition, the designs of many past studies on the choice of a business major have been criticized for lacking an explicit theoretical framework(D. Kim et al., 2002; Pritchard, Potter, \& Saccucci, 2004). Therefore, it is worth studying about students' motivation to choose a business major within the scope of a motivation theory.

\section{Theoretical considerations: Motivation theories}

Research on choice and decision making is essentially concerned with studying motivation. Although motivational theories have been explicitly addressed in this research literature review to varying degrees, it is pertinent to identify key motivation theories that underpin the study of student choice. In the following section, I identify key theories of motivation beginning with Bandura's social cognitive theory of selfefficacy, which has been influential to the theorization of motivation. Then, I move to discuss specific theories including the achievement goal perspective, social cognitive theory and expectancy-value theory.

\section{Social cognitive theory of self-efficacy}

Self-efficacy has been defined as belief in one's capability to successfully manage future situations (Bandura et al., 2001). A number of studies used social cognitive theories in studies of students' choice of major and career (Mau, 2000; Mclnerney et al., 2006) and some studies (Betz \& Hackett, 2006; Lent \& Brown, 2000; Lent, Sheu, et al., 2008) conducted with university students have shown a consistent relationship between self-efficacy beliefs and career choice behaviour.

It is noteworthy that researchers in career and motivation literature (Betz \& Rottinghaus, 2006; Lent \& Brown, 1984; Lent, Lopez, Lopez, \& Sheu, 2008; Lent, Sheu, et al., 2008)emphasized Bandura's self-efficacy theory (Bandura, 1977, 1986; Bandura et al., 2001). Lent and Brown (1984)identified a significant relationship 
between self-efficacy for scientific educational requirements and persistence in science and engineering majors.

Within self-efficacy theory, an individual's behaviour or change in behaviour is influenced by their expectations, which are based on belief in ability to successfully complete a task or behaviour. Self-efficacy both influences one's choice of behavioural activities, and one's persistence in pursuing courses of actions (Bandura, 1977, 1986; Bandura et al., 2001).

Bandura explained that "Efficacy beliefs play a key role in shaping the course lives take by influencing the type of activities and environments people choose to get into... Thus, by choosing and shaping environments, people can have a hand in what they become" (Bandura et al., 2001, p. 10). Bandura contends that, self-efficacy influences the productive functioning in both individualistic and collectivistic cultures. However, self-efficacy tends to be individualistic. Thus, people who are in collectivistic cultures where their decisions are dependent on others may be considered as having lower levels of efficacy (Bandura, 2001). Self-efficacy expectations are associated with the level of persistence and success in academic and career choices(Mclnerney et al., 2006).

In short, Bandura's (1986) social cognitive theory is a fundamental theory which has laid groundwork to other theories. Bandura's theory has been applied to career development(Betz \& Hackett, 2006; Betz, Klein, \& Taylor, 1996) and social cognitive career theory has been developed (Lent \& Brown, 1984, 1987).

\section{Achievement goal perspective}

Another growing body of work within motivation literature is focused on the reasons for doing a task and examines individuals' goals and goal mechanisms. An achievement goal perspective (Nicholls, 1984) assumes that some types of goal orientations lead to how students perform academic tasks. Prior literature grouped goal orientations into mastery goals and performance goals (Elliott, Hufton, Willis, \& Illushin, 2005; Nicholls, 1984). Mastery goals have been called learning goals in some studies (Dweck \& Leggett, 1988) and performance goals called ego goals (Nicholls, 1984). Students with mastery goals are interested in developing competence and understanding or skills. Mastery goals are intrinsic and their focus is on "learning, self- 
improvement and task mastery" (Kumar \& Maehr, 2007, p. 47). In contrast, students with performance goals focus on outperforming others and maximizing preferable evaluations of their ability (Kumar \& Maehr, 2007)

More recent work has divided goals into four groups including a mastery-approach goal, mastery-avoidance orientation, performance approach, and performanceavoidance approach (Anderman \& Patrick, 2012).Students with a mastery-avoidance orientation work to avoid a failure or mastery. Students with a performance-avoidance orientation want to avoid looking incompetent, lacking in ability or less than their friends (Elliott et al., 2005).

Interestingly, research on achievement goals has also been conducted in different cultural contexts (Ng \& Renshaw, 2002; Rao, Moely, \& Sachs, 2000). Ng and Renshaw (2002) found convergence between Chinese and Western students regarding the applicability and the effects of mastery goals and the different forms of performance goals. The relation between mastery and performance-approach goals among Chinese students was likely to be more consistently positive as compared to Western students.

A recent study involving young students explored how expectancy beliefs and values work together with goal orientation for Chinese students (Ho, Hau, \& Salili, 2007). This study surveyed 1,950 Chinese students in grade 7 in Hong Kong. Ho et al. (2007)found different levels of analysis of beliefs, values and goals. Some belief constructs such as self-efficacy were at a more task-specific level. The study concluded that these young Chinese students performed learning tasks with two major sets of cognition: self-estimates of achievement and perceptions about the values of such achievement. The study concluded that the perception of academic achievement has led an individual to perform motivated behaviour. Therefore, these students' decision making was seen to be influenced by their belief in their ability to achieve.

One of the main relationships between expectancy beliefs, values and goals is that a goal is influenced by two prominent factors: a person's history of performance and the cultural influences. Both the intrinsic and extrinsic values of a task are influenced by past experience (Vallerand, 1997). Vallerand asserts that previous competence performance is likely to increase an individual's interest in both engaging a task and persisting with it. Values and goals are relevant with reasons for academic 
engagement. However, values are more related to individuals' perspectives on the benefit of academic engagement whereas goals are more related to learning orientations in the current situation. Goals are core constructs in some career-related theories including social cognitive career theory and expectancy-value theory in which they are seen to motivate individuals for a choice and to engage in a chosen activity (Lent \& Brown, 2006). In the following sections, the place of goals in a number of theories is highlighted.

\section{Social Cognitive Career Theory (SCCT)}

In the 1980s there was an increasing emphasis on theoretical explanations to understand career choice and influencing factors. Lent, Brown, and Hackett (1994) developed the Social Cognitive Career Theory (SCCT), which is associated with basic career development process based on general Bandura's social cognitive theory (1986). In the literature SCCT also referred to Social Cognitive Choice Theory (Lent, Lopez, et al., 2008)The SCCT's framework outlines a process of career and interest development, career-related choices, and performance outcomes. (Lent, Lopez, et al., 2008)pointed out that the SCCT model is appropriate for framing students' decision making at earlier stages of enrollment as well as more advanced students. Lent, Lopez, et al. suggest that the SCCT model can be used across gender, educational level and university type.

\section{SCCT's major constructs}

Early and ongoing research has utilized an academic and career-related self-efficacy construct to understand individuals' interests, choice and performance (Lent \& Brown, 1984). In more recent studies, some social cognitive variables such as outcome expectations and goals have been included in SCCT (Lent \& Brown, 2006; Lent, Brown, \& Hackett, 1994; Lent, Lopez, et al., 2008; Lent, Sheu, et al., 2008).

One of major constructs of SCCT is self-efficacy. Content-task-specific self-efficacy is an individual's beliefs in his or her ability to complete a specific task. SCCT research also utilizes process efficacy, or the perceived ability to manage important tasks that occur prior to, during and after career entry (Lent \& Brown, 2006). An example of process self-efficacy is self-efficacy in making vocational decisions (Betz et al., 1996).

The source of self-efficacy is important for understanding self-efficacy in career- 
related studies as it provides more insights into how self-efficacy, related to a given task or choice, can be acquired (Lent \& Brown, 2006).

Another construct of SCCT is outcome expectations, which can be defined as individuals' beliefs about the consequences of their performance or choice. "Whereas self-efficacy beliefs are concerned with one's capabilities (e.g., 'can I do this?'), outcome expectations involve imagined consequences of particular courses of action (e.g., 'If I try doing this, what will happen?')" (Lent, 2005, p. 104). A person chooses to do a task (e.g., career/major choice) because he or she expects certain social outcomes (e.g., advantages to his/her family), material (e.g., financial benefits), and self-evaluative (e.g., self-approval) outcomes (Lent, 2005).

Goals are another construct of SCCT and they can be grouped as mastery goals and performance goals (Lent et al., 1996). A student's intention in choosing a major is considered a choice or mastery goal, which will motivate them to pursue their academic/career choice while performance goals are associated with promoting the quality of achievements and the level of achievement (Lent, Sheu, et al., 2008).

Another core construct of SCCT is interests: structures of how people like, dislike or differentiate various activities (Lent et al., 1994). Self-efficacy, outcome expectations and interests are major constructs in SCCT and in Eccles' (2009) expectancy-value theory which will be elaborated later in this chapter.

SCCT models the development of basic career and academic interests and how these interests encourage people to engage in career-related tasks and skill development(Lent et al., 1994). Interests are promoted by self-efficacy and anticipated outcomes specifically when expectations are positive and there is strong selfefficacy(Lent, Lopez, et al., 2008). In this model of basic career and academic interest development, outcome anticipations are influenced by self-efficacy. If individuals believe that they are efficacious at a task, this leads to their expectations of achieving positive outcomes. Then, the anticipated outcomes influence activity goals and choices.

An individual's interest in a career-related or academic activity is influenced by the expected outcomes of engaging in the activity as well as the value of these outcomes. Within this model, self-efficacy and outcome expectations directly influence activity 
goals and choices. Lent, Lopez, et al. (2008)found support for self-efficacy being a prominent predictor of outcome expectations, but they found no evidence that outcome expectation had a direct influence on interest and goals.

\section{Model of career/academic choice in SCCT}

The career/academic choice model extends the model of interest development (Lent et al., 1994). The process of career/academic choice is grouped into the following phases: selection of a major choice goal out of an individual's career interests, activity which is managed to achieve the choice goal such as enrolling in a university major, and performance achievements. Lent et al. point out that career choice goals differ from choice actions. This distinction becomes useful because grouping the choice process in this way can emphasize the important influence of personal goals on choosing a major/career. Moreover, choices are not fixed because they will be adjusted after an implementation. Lent et al. gave a clear example of a student choosing a major, for example engineering, then experiencing difficulties or challenges which lead them to review their capabilities and this may lead them to choose a new major.

Some researchers argue that SCCT overemphasizes the self-efficacy construct in representing it as a key predictor of vocational behaviour and career choice. Armstrong and Vogel (2010)critiqued the relationship between interests and efficacy in SCCT. Armstrong and Vogel contended that while research has shown a direct relationship between interest and efficacy, SCCT model fails to include a reciprocal path between interests and self-efficacy. In SCCT, self-efficacy is depicted as having a direct influence on interests while the influence of interests on self-efficacy is seen as indirect. For these reasons, Armstrong and Vogel recommended a model based on Holland's (1973) theory. Armstrong and Vogel regarded the model developed by Holland (1973) as having a parsimony advantage over the SCCT model. Armstrong and Vogel (2010)proposed the use of Holland's RIASEC model as an alternative theory to SCCT by Lent et al. (1994) in studying how choices of career are developed and influenced by an interaction between individual differences and learning experiences. The next section outlines Holland's theory. 


\section{Holland's theory: RIASEC}

Holland's theory has developed over the past four decades(Holland, 1973, 1997). This theory of vocational choice provides a framework to explain students' choice of university majors. The initial theory involved six personality types including realistic, investigative, artistic, social, enterprising and conventional (RIASEC) (Holland, 1973). Holland (1973) depicted realistic types as people who engage in activities related to machines and tools and they are not interested in educational and social activities whereas investigative types prefer activities, which require exploration, understanding and predictions. Investigative types tend to dislike activities related to persuasion and sales, and value knowledge and attainments in science and technology. Artistic types are interested in arts, literature, and music, and dislike following set rules. They value creativity. Social types like to instruct and help others. They avoid mechanical and technical activities. They value education and social service. Enterprising types are interested in encouraging and directing others to achieve common goals. They dislike scientific and intellectual tasks. They value political and economic attainments. Lastly, conventional types like to achieve goals by doing routine tasks. They dislike unstructured performance (Holland, 1973). The six personality types and perceived academic major influence student's expectations (Pike, 2006).

In more recent years, the theory has added three factors: persons, environment and the interaction between persons and their environment. For example, in the higher education context, the components in Holland's framework are students, their majors, and the interactions between students and their chosen majors. The interaction between persons and their environment has been included as a third component in Holland's theory. In Holland's theory, the three components have developed three aspects about university students and their choice of major. Firstly, students tend to choose a major that is relevant to their personality (self-selection). Secondly, academic majors develop students' competence and interests (socialization), and lastly students prefer the environment, which matches with their personality types (congruence). Prior and recent studies support the three aspects (Holland, 1973; Pike, 2006).

Holland's theory identifies key components for a person engaging in an activity or choice of major. However, it fails to provide a clear framework on the process that is on how motivation is formed while SCCT and expectancy-value theory have clear frameworks. 


\section{Expectancy-value theory}

Social Cognitive Career Theory (Lent \& Brown, 2006; Lent, Lopez, et al., 2008) assists understanding of career choice development including highlighting the aspects of self-efficacy, outcome expectations, goals, and choice as pertaining to career development. The choice of a major is one aspect of career choice and career development. The work of Eccles and colleagues on expectancy-value theory provides an additional lens that enables the examination of one aspect of career development at one point in time, namely that of choice of major (Jones et al., 2010; Matusovich et al., 2010).

Eccles and her colleagues saw an overlap between aspects of expectancy-value theory and SCCT (Lent et al., 1994) including ability beliefs, outcome expectations, and interests. Values and interests are framed within outcome expectations in SCCT. The expected outcomes from an activity and the importance of such outcomes to the individual have an impact on the interest in an activity. However, Matusovich et al. (2010) contend that expectancy-value theory provides a more explicit framework to examine students' beliefs about their career choices. Expectancy-value theory predicts that students' expectancies for both achievement and values have a direct influence on their performance, and life-defining choices, including university majors and career choice (Eccles, 2009). In recent years researchers working on career-related choice and motivation have favoured expectancy-value theory (Eccles, 2009; Jones et al., 2010; Matusovich et al., 2010). Therefore, the expectancy-value theory has been selected for the current study.

Expectancy-value theory focuses on the "social psychological reasons for people's choices in achievement settings; thus, expectancy and value are defined as cognitive rather than purely motivational constructs" (Wigfield \& Eccles, 1992, p. 278). Expectancy-value theory emphasizes the value placed on goals and tasks as major factors which lead an individual to choose an activity over another (Elliott et al., 2005).

\section{Expectancy beliefs versus value beliefs}

Expectancy-value theory identifies two major sets of beliefs; expectancy or expectancy and value (Eccles, 2009). These beliefs are the individual's expectation for success, and the value placed on available choices. Eccles' model links these beliefs as 
underpinning an individual's "life defining behavioural choices," such as career choice (2009, p.79).

Expectancy and value beliefs are influenced by major factors including prior personal experience, important socializers (e.g., teachers, parents, and friends), cultural milieu (e.g., gender, stereotype of activities, and the nature of ability), self-knowledge and future goals, and collective identity beliefs (Eccles \& Wigfield, 1995).

Value beliefs refer to the desire of individuals to engage in, or the importance placed on doing a task or activity whereas expectancy beliefs refer to a person's ability to do a task or engage in an activity (Eccles, 2009; Eccles \& Wigfield, 1995). Expectancy beliefs have been described as a number of expectancy beliefs and self-schemas that underpin expectations for achievement in academic tasks (Eccles \& Wigfield, 1995).

Within expectancy-value theory, expectancy beliefs refer to students' beliefs about business. From a student perspective, this involves asking the question: Can I earn a business degree? In contrast, from a student perspective, value belief involves asking the question: Do I want to earn a business degree? A simplified view of Eccles' expectancy-value theory follows (see Figure 2.1).

Even though expectancy or ability beliefs are strong predictors for engaging in academic tasks, they do not directly address the reasons students have for performing those tasks. Therefore, the value component of expectancy-value theory is also essential for a deeper understanding of motivation for a task performance and achievement motivation (Ho et al., 2007). 
Figure 2.1. The relationship between expectancy and value beliefs and the motivated action to earn a business degree

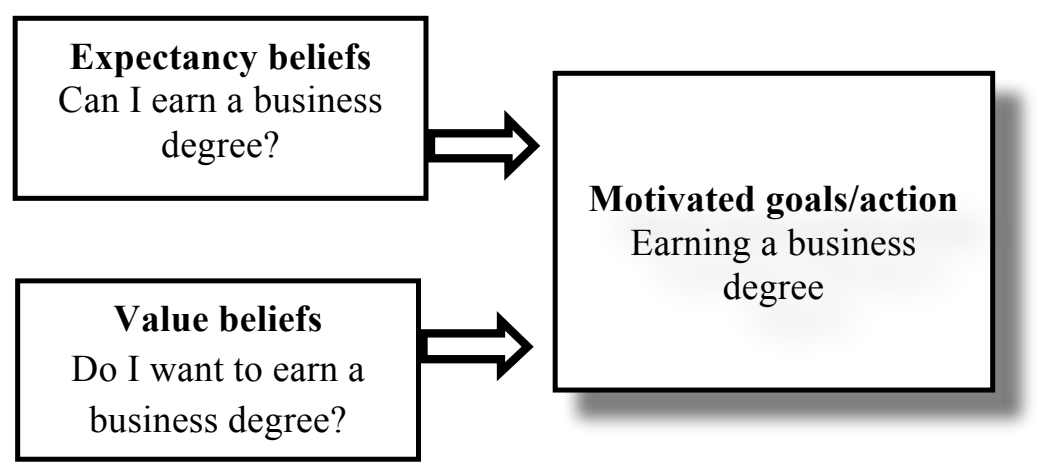

Source: Adapted from Matusovich et al. (2010, p.290)

It should be noted that value beliefs have been studied less widely than expectancy beliefs across all age groups (Matusovich et al., 2010). However, value beliefs are no less significant. The theory claims that students' expectancies for success influence their performance on a task, whereas their achievement task values are strongly related to their intentions and choice of activities. Thus, value-related constructs are preferable for a study of students' intentions and choice of activities. In recent research, Jones et al. (2010) examined three relationships among major motivation constructs for 363 first-year engineering students (female and male): expectancy-related constructs including self-efficacy and achievement expectancy, value-related constructs and engineering values, and engineering success and career plans. This quantitative study found that value-related constructs provide a better prediction of future career choice than expectancy constructs. Therefore, there is value in studying the value beliefs of students and their future career aspirations.

Expectancy-value theory consists of four subjective task value categories including intrinsic interest-enjoyment value, attainment value, perceived cost, and extrinsic utility value. Subjective task values refer to the perceived quality of a task, which increases or decreases the probability that a person will choose it (Eccles, 2009; Eccles $\&$ Wigfield, 1995). The four subjective task values are now briefly discussed. 


\section{Attainment value}

Attainment value refers to the perspective of a person as to how an activity engagement reflects on the person and how this reflection matches with self-concept (Wigfield \& Eccles, 1992). Students choose to engage in business degrees because it is consistent with their sense of self. Attainment value is conceptualized in relation to personal and collective identities (Eccles, 2009). Individuals shape their own image of who they are and who they would like to be in the future when they mature. This selfimage influences the choice of an individual's education and career. Matusovich et al.(2010) described that sense of self was always the reason the engineering students in this study chose to engage in and persist in earning a degree. Their study also revealed that a career decision-making process is more consistent with students' self-concept (attainment value) than with interest value.

\section{Interest-enjoyment value}

Interest value is an individual's enjoyment experience in engaging in the activity. A person values a task once he or she is interested in it and this interest value can become an attainment value (Eccles, 2009; Eccles \& Wigfield, 1995). Interest value is considered to be important within some career decision-making models (e.g., Lent et al., 1994; Super, 1980). The importance of interest value in selecting business majors has been highlighted in a number of studies (e.g., D. Kim et al., 2002; Malgwi et al., 2005; Mauldin et al., 2000). Interest value is salient to major choice as well as career decisions.

\section{Perceived cost}

"Perceived cost" refers to the cost of engaging in an activity (Eccles, 2009). Eccles framed the perceived cost in terms of effort, time or psychological impact. The costs include expected anxiety, fear of failure, and fear of the social consequences of success. Because of limited time and energy, people must choose among activities. This means that a person who engages in activity ' $A$ ' might have to forgo another activity.

\section{Utility value}

Utility value is based on the anticipated importance of doing a task (Wigfield \& Eccles, 1992). For example, some majors are popular because students perceive that 
these majors will lead to careers that provide freedom in making decisions, prestige, and professional advancement (Lysonski \& Durvasula, 1998; Swenson et al., 1993). D. Kim et al. (2002)andMalgwi et al. (2005) identified top reasons for students to choose a business major including job opportunities and potential for career advancement. D. Kim et al. (2002)pointed out that while business and management students emphasized the importance of how their major would help them become selfemployed, finance majors were more likely to consider projected earnings as more important compared with other majors. To sum up, the choice of major or career is influenced by the perceived future importance of the major and career.

Overall, the current review has shown different ways expectancy-value theory has been used to understand students' choice of a major and/or career. Core components of choice of a major was from goals including mastery and performance goals and personality traits in Holland's theory to key constructs in social cognitive theory and expectancy-value theory. These motivation theories have been influential in the research field of major and/or career choice. Taking this into consideration, the current study will utilize the expectancy-value theory with a consideration of the relevance of the theory to Cambodian context within Asian culture.

Expectancy-value theory identifies the main factors influencing choice of a major and/or career. They perhaps are not sufficient for developing insights into the actual decision-making process and how students come to choosing a major. It is worthwhile studying the decision-making process of students related to their choice of major/or career.

\section{Choosing a major or career as a complex decision-making process}

As mentioned earlier, expectancy-value theory is important for explaining factors involved in students' choice of a major and/or career. It should be noted that a complementary focus on how students go about making their decisions would enrich understanding on students' choice of a major.

Interestingly, in the New Zealand context concern has also been expressed around the mismatch between students' choice in terms of tertiary study, and labour market needs. In order to progress understanding of the underlying issues, the New Zealand Ministry 
of Education commissioned a review of research on the processes and factors involved in students' decision making (Leach \& Zepke, 2005).

Leach and Zepke (2005)provide a decision-making model which is relevant to how students make an important academic decision including students' choice of a major and/or career.

\section{Major choice: Decision-making model}

Leach and Zepke (2005)utilized Hossler and Gallagher's (1987)three-phase decisionmaking model to structure their review. The model's three phases are predisposition, search and choice (Leach \& Zepke, 2005). Predisposition considers family background, parental disposition towards higher education and degree of self-belief, factors which have also been addressed within studies shaped by expectancy-value theory. The search stage focuses on the person looking at higher education options and considers variables including career aspirations, interest in the major, academic achievement, information accessibility, and contact with higher education institutions. The final stage of the process is choice, and centres on the choice to pursue specific university majors.

The factors Leach and Zepke identified as influencing students' decision-making process intersect with the major constructs of the expectancy-value theory. These factors included self-belief in ability and academic achievement (attainment value belief), subject area interest (interest value belief), career outlook (utility value belief), and cost.

The three-phase model overlapped with the four significant themes that emerged from the analysis. The four themes are (a) decision-making process, (b) the factors that inform the decision-making process, (c) information requirements that support decision making, and (d) the impact of diversity on decision making (see Figure 2.2).Thus, the model complements expectancy-value theory, and the following section draws on Leach and Zepke (2005), and sources identified in their review to elaborate on the model and its relevance to the current study. 
Figure 2.2. Working model for decision-making process

\begin{tabular}{|c|c|c|c|}
\hline Decisions & Factors & Information & Diversity \\
\hline Predisposition & $\begin{array}{l}\text { - Socio-economic status } \\
\text { - Parental disposition } \\
\text { - Self belief in ability } \\
\text { - School }\end{array}$ & - Family experience & $\begin{array}{l}\text { - Socio-economic } \\
\text { status } \\
\text { - Gender } \\
\text { predispositions } \\
\text { - Cultural habitus }\end{array}$ \\
\hline Search & $\begin{array}{l}\text { - Career } \\
\text { outlook/aspirations } \\
\text { - Academic } \\
\text { achievement } \\
\text { - Subject area interest } \\
\text { - Institutional profile } \\
\text { - location } \\
\text { - courses offered } \\
\text { - reputation/ image } \\
\text { - Costs and financial aid } \\
\end{array}$ & $\begin{array}{l}\text { - Information networks } \\
\text { Interpersonal } \\
\text { information } \\
\text { - school } \\
\text { - home } \\
\text { - peers } \\
\text { - Contact with tertiary } \\
\text { providers } \\
\text { - taster courses } \\
\text { - involving parents } \\
\text { - brochures }\end{array}$ & $\begin{array}{l}\text { - Different aspirations } \\
\text { - Minorities } \\
\text { - have community } \\
\text { orientation } \\
\text { - job often more } \\
\text { important } \\
\text { - Gender differences }\end{array}$ \\
\hline Choice & $\begin{array}{l}\text { - Right courses/degrees } \\
\text { - Admission } \\
\text { - Social fit }\end{array}$ & $\begin{array}{l}\text { - Communication with } \\
\text { institution of choice } \\
\text { - open days } \\
\text { - information on } \\
\text { needs }\end{array}$ & $\begin{array}{l}\text { - Cultural differences } \\
\text { - Gender differences } \\
\text { - Age differences }\end{array}$ \\
\hline
\end{tabular}

Source: Leach and Zepke (2005, p. 15)

\section{Information for the choice}

Students seek information before making a decision about selecting a major. Leach and Zepke (2005) have identified several information sources for prospective tertiary students including family experiences of higher education, interpersonal information, and information sharing between students, families, schools and universities.

Maxwell, Cooper, and Biggs (2000)argue that mass information such as newspapers, radio and television are not effective in informing students' decision making. Research has suggested that the most effective information in decision making derives from social networks, which require interpersonal communication (Christie, Munro, \& Fisher, 2004). Interpersonal information networks include parents, families, friends, teachers, career counselors and tertiary staff (Brooks, 2004). A longitudinal study in New Zealand explored the impacts of a non-conventional programmes for at-risk students on the students' decision making (Boyd \& MacDowall, 2003). The researchers interviewed 75 students from seven low-decile schools. The research found that teachers were ranked as the most important influences in the decision-making process, followed by family and peers(Brooks, 2004). 
It is likely that when parents have experience of higher education, children have more confidence about their study choices(Connor et al., 2001). Parental education has been shown to be an essential factor in the decision-making process. Friends and other family members, who have current or recent higher education experience may also have positive influence on the process (Connor et al., 2001).

\section{Diversity}

\section{Gender difference in decision making}

A wide range of research has found that female and male students follow different decision-making processes (Lackland \& Lisi, 2001; Leppel, Williams, \& Waldauer, 2001; Montmarquette et al., 2001). Brennan (2001)examined the influence of career counselors and the relationship between the choice of university and students' use of information sources. Brennan surveyed 735 first-year students in three universities in Melbourne, Australia. The study found that female and male students were influenced by advisors such as parents, teachers and friends in different ways. Females reported preferring family members and friends as advisors whereas boys preferred professional advisors such as career counselors.

\section{Influence of geographic location}

The geographic location of a university or proximity to the student's home is another factor influencing the decision making of students in terms of which university they will attend and choice of major (Brennan, 2001). Past research suggests two views of the effects of location. First, some students want to go to an institution, which is close to their home so that they can be with their families and their support networks. In contrast, some students prefer a chance to move away from their home (Ming, 2010).

\section{Cultural influences on motivation and choice of major}

Cultural influences are salient in career related decision making (Lent et al., 1996) and motivation for a choice of behaviour (Pajares, 2007). Pajares contends that "research findings and generalizations drawn from educational psychology broadly, and motivation theory and research in particular, cannot be taken as general rules that are independent of contextual variation" (2007, p. 19). 
There has been little research on cultural influences on choice of major and career in Cambodia. Research for a Master's thesis found that family or other relatives influenced the choice of a private or public university in Cambodia (Leng, 2010). It is likely that the culture may influence the decision-making process and students' motivation to choose a major.

The cultural values of Cambodian students will be shaped by traditions that value collectivism and families over individualism (Chhim, 1987). In many Asian cultures and traditions, parental and familial expectations have significant influence on the career decision-making process. Individual's career-related choices are likely to be a family choice because children are expected to take care of their parents when they are elderly (Mau, 2000; Oyserman, Coon, \& Kemmelmeier, 2002). This cultural emphasis may lead Asian youth to choose careers that not only benefit themselves but ones that they can use to help other siblings or provide care to elderly parents (Song \& Glick, 2004).

A wide range of past research has highlighted the difference between Asian and Western decision-making processes and some studies have been conducted in Asia including Thailand (Hughes, 2011), Korea (Lee \& Rojewski, 2012), China (Mau, 2000), and Hong Kong (Hesketh \& Rounds, 1995). A cross-cultural study conducted in China and Hong Kong by Hesketh and Rounds (1995) demonstrated that a Western work culture values independence whereas Asian work cultures value a more collectivistic approach. Similarly research in China by Mau (2000) and Oyserman et al. (2002) and a study in South Korea (Lee \& Rojewski, 2012) found Western people to be more individually oriented whereas Asian people were more influenced by group conformity (i.e., by family, friends, teacher, or work unit).

Another study revealed the difference between Australian and Thai culture (Hughes, 2011). Hughes found that Australian culture had a relationship with individualism and independent self-construal, whereas Thai culture was associated with collectivism and interdependent self-construal. His findings support findings in previous studies (e.g., Mau, 2000; Hesketh et al., 1995; Oyserman et al., 2002). 
Therefore, in this study, particular attention will be paid to cultural influences on Cambodian students' choice of a major, and also to what, if any, were the shortcomings of the expectancy-value theory for understanding motivation in this context.

\section{Summary of the chapter}

In summary, this chapter described the literature search and then went on to discuss past research relevant to the topic and approaches used to study motivation to perform a task or making a choice. A wide range of research has been conducted in the area of choice of a major with different focuses. Some key motivational theories were discussed in the current review and they included social cognitive theory of selfefficacy by Bandura et al. (2001), the achievement goal perspective (Elliott et al., 2005; Nicholls, 1984), Holland's theory $(1973,1997)$, social cognitive career theory (Lent et al., 1994) and Eccles' expectancy-value theory (2009). Eccles' expectancyvalue theory (2009) provides a clear lens to explore students' beliefs and motivation in choosing a major or career. Leach and Zepke's framework for examining students' decision-making processes is compatible with expectancy-value theory and has potential to embrace the decision-making process as well as the factors that influence choice of a major and career.

Most of the chapter focused on motivation theories with particular attention paid to SCCT and to expectancy-value theory. Consideration was given to the three stage decision-making process model from Leach and Zepke's 2005 review because of its relevance to the question of how students choose their university major.

The current study extends prior research to choice of major in several ways. First, rather than including a sample of various disciplines, this study focused on Cambodian students with a business major. Second, the current study employs a psychological theory, expectancy-value theory, to describe students' motivation to choose a business major and career while prior studies mostly utilized survey frameworks. Third, there has not been sufficient research in Cambodia on motivation to choose a business major. This research is very useful in addressing the application of expectancy-value theory to understand motivation for a choice of major in a different cultural setting. 


\section{Chapter Three: Methodology}

\section{Introduction}

This chapter describes the methods used to accomplish the research. It sets out the research methodology, characteristics of the participants, context of the research, data collection and analysis. It also discusses the strategies used during the research to ensure its reliability and trustworthiness. The ethical considerations of such research are also discussed. In the first section, the justification for a qualitative case study is set out. In the second section, a description is provided of participants and how they were recruited. The third section outlines the contextual setting of the research. Then, it explores the methods and tools used for collecting data. The chapter concludes with a discussion of the reliability and trustworthiness of the research.

\section{Research design}

This study was designed to be a qualitative study as this type of research is helpful for understanding people's experiences and their perspectives (Johnson \& Christensen, 2008; Merriam, 2002). Similarly, McMillan suggests that the purpose of qualitative research is to "know how and why behaviour occurs"(2008, p. 273). For example, in this study, I wanted to know how and why the participants chose finance and banking. Moreover, qualitative data is rich and holistic and provides "thick descriptions that are vivid, nested in a real context and are also well suited for locating the meanings people place on events, processes and structures"(Miles \& Huberman, 1994, p. 10).This qualitative study aimed to provide an in-depth understanding of how and why a sample of Cambodian students chose to enter business-related degrees. Therefore, a qualitative approach was most appropriate to explore students' experiences of selecting a major and perspectives on their future careers.

Qualitative research approaches which can be used to understand participants' personal perspectives include basic interpretive qualitative study, phenomenology, case study, and narrative analysis (Johnson \& Christensen, 2008; Lichtman, 2010; Merriam, 1988, 2001, 2002). I chose multiple-case study as the research method for this study as I wished to gain an in-depth understanding of how and why students chose business 
degrees. A multiple case study allows deeper understanding of, and additional context for, the individual cases. Moreover, it can provide an in-depth description and analysis of an event or social system(Miles \& Huberman, 1994).

I considered the decision of students to major in a business degree as both an event and a social system. An event, in this case, was the choice that students made, which is a life event starting from the beginning of their degree until completion (Lichtman, 2010; Merriam, 2002). A social system as Matusovich et al. (2010) described is the decision-making process to pursue their degree based on their experience, perspectives, and the influence of relevant factors including faculty, peers and family members. Therefore, a multiple case study allowed me to understand the choice students made from the beginning of their degree and the influence of relevant factors on students' decision-making process to earn a business degree.

\section{Setting}

The study was conducted in Cambodia, specifically in a public provincial university, the University of Battambang (UBB) in Battambang province. This province is one of the largest in the northwest region of Cambodia and its town is ranked the second largest city in Cambodia. The population of Battambang province is 1,205,174 of which 518,823 are female(Ministry of Planning, 2008).

UBB is the only public university in the province and was founded in 2007 by H.E. Sor Kheng, the Deputy Prime Minister of Cambodia. Its vision is to provide educational opportunities to rural students especially from northwestern Cambodia. The university has six faculties: (1) Business Administration and Tourism, (2) Science and Technology, (3) Agriculture and Food processing, (4) Sociology and Community Development, (5) Arts, Humanities and Education, and (6) the Institute of Foreign Languages.

In the academic year of 2011-2012, UBB had 5,720 students $^{1}$ (41.14\% females). More than half of all students were doing their degrees in the Faculty of Business Administration and Tourism. The Faculty of Business Administration and Tourism

\footnotetext{
${ }^{1}$ Source: Unpublished report from UBB.
} 
offers five majors including accounting, finance and banking, management, marketing and tourism. Eleven lecturers teach sub-degree programmes and 202 lecturers including 20 foreign lecturers teach undergraduate and postgraduate programmes.

Students are required to do a foundation year, which includes fundamental subjects such as maths and philosophy and introduces them to their chosen major. Students start studying a specific major from their second year. The foundation year programme aims to improve students' capabilities in basic knowledge in theoretical and practical studies. Students are allowed to change their major up until the beginning of the second year.

\section{Ethical considerations}

Even though there are no specific ethical guidelines in Cambodia, a procedure to gain consent was organized within a hierarchical administration from the top level, the Ministry of Education, Youth and Sports (MoEYS), the university and finally with students. First, after receiving approval from the Human Ethics Committee of the Faculty of Education of Victoria University of Wellington, I asked for a letter certifying my student status and research topic from the university. This letter was sent to MoEYS to receive permission to conduct research at UBB. The rector of UBB approved naming UBB in the thesis. There was an arrangement for a study presentation to the faculty and then to the target classes. The foundation department was asked to arrange first year finance and banking classes for my study presentation. This presentation allowed students to make an informed decision when volunteering to participate in the research.

The research was conducted with care and respect for the research participants. Thus, it was important to ensure that participants received clear information about the research, and felt free to decide about their participation without any obligation. I recognized a possibility that students might feel obliged due to my employment in the university and I was aware of a Cambodian culture where younger people respect seniors. To minimise this possibility, students were clearly informed that they were not obligated to participate in this research and I asked them to accept my role as a researcher - not a lecturer. I tried to create a friendly and relaxed environment during the presentation and interviews. 
Students were informed that the interviews would not interfere with their classes. A convenient time for them would be arranged. They were allowed to withdraw their participation within a reasonable time (no later than a week after their interview). They made their own decision as to whether to participate or not. Informed consent is an important ethical principal (New Zealand Association for Research in Education, 2010). For this reason the briefing to the students, the information sheet and the consent forms were in Khmer (the language of Cambodia) to ensure students understood. To minimise risk, I ensuredparticipants would not be identifiable, and their personal information was kept confidential. In the written report they will be referred to by a Khmer pseudonym. Only my supervisor, the transcriber and I had access to this confidential data.

\section{Research participants and recruitment}

This study utilized a purposive sampling method. Purposive sampling is usually the most appropriate sampling strategy for qualitative research because it is based on what the researcher wants to "discover, understand, and gain insight and therefore must select a sample from which the most can be learned"(Merriam, 2001, p. 61). The finance and banking major was chosen because it represented $43.64 \%$ of all students enrolled in business-related majors including accounting, management and marketing at UBB in 2012. The current study included ten students, who were majoring in finance and banking in their foundation year at UBB.

The recruitment of ten participants began after receiving ethical approval (see section above) from the MoEYS and from the rector of UBB. The foundation director and staff arranged for me to introduce my research to two sessions of finance and banking classes. The first session was attended by approximately 100 students, and the second one attended by approximately 70 students. Students were encouraged to ask questions about the research before they decided to volunteer. Students indicated their willingness to be involved in the research by completing a sheet for volunteers and providing basic information such as gender, age, address, student status (i.e., scholarship or fee-paying), and contact telephone and email address. A total of 33 students volunteered to participate in the research. It should be noted that only six volunteers were male. More female students appeared to be interested in participating 
in the research as they asked more questions about the research at the presentation. In order to select ten participants, I used the criteria as below:

(1) Variety of female and male students (50\% of the participants are female),

(2) Inclusion of some scholarship students,

(3) Variety of local students and students from other provinces.

Out of the 33 volunteers, five female and five male participants were selected using the following procedure. I grouped the 33 volunteers into two groups - male and female. In the male group of six, I used the above criteria to select only five students. One student was excluded because he could not be reached at his given contact telephone number. Thus, five male participants were chosen.

It was harder to select five female students out of the 27. One volunteer was automatically selected because she was the only scholarship student who volunteered to participate in the research. Two female students were selected because they were from other provinces. Unfortunately, one could not come to the interview because she was away visiting her family. So a new participant was selected. In order to select the three female volunteers out of 25 , I classified them according to the place they were from. Because there were few students from other provinces, volunteers who were from rural areas in Battambang were selected because it is interesting to learn about how students value their study regardless of the distance they travel to study. Two students from the town were chosen and one was from a district of Battambang province. A final list of selected participants is shown in Table 1. 
Table 3.1. Participants' demographic information

\begin{tabular}{|c|c|c|c|c|c|}
\hline No & Pseudonym & Gender & Age & From & Living with \\
\hline 1 & Mony & M & 21 & Neighbouring province & Aunt \\
\hline 2 & Chamnab & M & 20 & Local district & Family \\
\hline 3 & Sophy & F & 19 & Distant province & Uncle \\
\hline 4 & Mara & M & 24 & Local district & Family \\
\hline 5 & Boeb & M & 22 & Urban & Family \\
\hline 6 & Navy & F & 18 & Urban & Family \\
\hline 7 & Sam & M & 19 & Neighbouring province & Renting a flat \\
\hline 8 & Sokha & F & 22 & Rural & An organization \\
\hline 9 & Phally & F & 20 & Local district & Family \\
\hline 10 & Chea & F & 19 & Urban & Family \\
\hline
\end{tabular}

\section{Data collection, methods and tools}

Qualitative interviewing is the most popular form of data collection for qualitative researchers (Johnson \& Christensen, 2008; Lichtman, 2010). According to Patton (1987), interviewing enables a researcher to gain insights into the internal world of the participant and to get an in-depth understanding of that participant's perceptions (Merriam, 2001). Semi-structured interviews were employed in this study because they provide a clear set of instructions for interviewers. An interviewer can vary the questions as the situation demands which enables more flexibility then a structured interview (Lichtman, 2010).

A question list (see appendix A) was prepared based on the questions developed by Matusovich et al.(2010). Their question list is relevant to this study as it was designed to build understanding of how and why students choose a major. The questions were translated into Khmer for the interviews. The interviews were in Khmer due to a number of reasons. First, the participants' English proficiency was at a level where they could not share detailed information. Moreover, students felt more comfortable speaking in their native language. It is important for students to feel comfortable in expressing their feelings and sharing their stories. 
The question list consists of five main questions. The first two questions were to answer the first research question which focused on how and why students chose finance and banking and why they did not choose other majors. These two questions brought a deeper understanding of how students' beliefs contribute to their choice of major. The last three questions were asked to answer the second research question, which was to understand factors influencing students' future career plans. Probe questions were asked in order to receive rich information.

\section{Semi-structured interviews}

Before the interview began, the participants were again informed about the research purpose. Students were encouraged to ask for any clarification about the research and interviews. Students were reminded that interviews were to be audio-recorded. The participants read the information sheet and signed the consent form. Each interview lasted approximately 60 minutes.

Merriam suggests an effective beginning, which is to be "respectful, non-judgemental, and nonthreatening"(2001, p. 85).The interview began with some general questions (e.g., about their study history) to make the participant feel comfortable in speaking with me and to gradually gain their trust. More topic-directed questions were asked subsequently. I used both note-taking and a digital voice recorder during the interview in order to avoid the loss of information given by the participants (Merriam, 2001).

Interviews were conducted in a room in the university and this created constraints around times to access the room. In addition, I was conscious of needing to complete the interview within an hour or to enable students to attend their next class. Students who arrived late for the interview added to a sense of urgency to get through questions. One participant cancelled the appointment for the interview twice. I decided to select another volunteer to replace them. Two participants visited their hometown during their school holidays and it caused delays in completing the interviews.

I wrote my reflections immediately following each interview. The reflections consisted of descriptive notes on the behaviour, verbal and nonverbal, of the participants, and my perceptions of the participants' level of commitment to their choices. The reflection 
notes were useful because I could use them to monitor the process and begin to analyse the information itself (Merriam, 2001). Students were asked for further contact for more information if the researcher required.

\section{Data Analysis methods}

\section{Transcribing the research data}

The transcripts were produced manually by using the voice recording and the notes in Khmer. I transcribed three interviews while my friend, who is an experienced researcher, transcribed the other seven interviews. The Khmer transcripts were sent to the research participants for checking and comments. The only feedback received focused on minor issues such as correction of pronouns. After receiving the feedback from the participants, I started to translate the transcripts into English.

After the translation was finished, I reread the transcripts and often referred to the original Khmer transcripts to make sure there was not a mistake or a mistranslation. Reading the transcripts again and again helped me to get a general overview of the research responses. Then, I began summarizing each interview in order to have a better understanding of all participants' responses. The summaries provided a low level of initial analysis(Lichtman, 2010). In keeping with qualitative approaches I engaged in member checking by emailing the summary to each participant for feedback(Johnson \& Christensen, 2008).

\section{Within and cross-case analysis}

Multiple case studies involve two phases of analysis including within-case analysis and cross-case analysis (Merriam, 2001; Miles \& Huberman, 1994). I applied the analysis approach as described by Miles and Huberman (1994). Miles and Huberman (1994) formed data analysis strategies into three groups including case-oriented, variable-oriented, and mixed strategies. The case-oriented approach focuses on the individual cases (i.e. each student participant) whereas the variable-oriented approach emphasizes the variables identified within individual cases and across cases (i.e., the four Subjective Task Value constructs). This study employed a mixed strategy, where both strategies were combined. 
First, the data is categorized into cases. To begin the case-oriented approach, the ten interviews were coded first by open-coding strategies, developing codes inductively from the data. Even though coding analysis was shaped by the expectancy-value theory, I initially intended to use open-coding in order to approach the code transcripts with an open mind. By doing this, I could reduce the possibility of missing unexpected and important insights, which may be raised by participants (Johnson \& Christensen, 2008; Lichtman, 2010). I read each transcript and made notes in the margins of words, short phrases and links to theories that summed up what was being said in the text. This allowed for a summary statement or word for each element that was discussed in the transcript to be identified.

Next, the codes were refined. I collected all the words and phrases from the interviews onto a clean set of pages. These could then be worked through and all duplications crossed out. This had the effect of reducing the numbers of 'categories' quite considerably. A final coding framework after reduction of the categories in the initial coding framework was developed.

After each case was analysed separately, I started looking across cases for themes and patterns. My supervisor checked the appropriateness of coding before and after the preliminary analysis. The summaries of the interviews had provided a low level initial analysis. The further processing of the summaries therefore provided more understanding of each case and strengthened the quality of coding and analysis (Merriam, 2002). The preliminary result was refined by looking for uniqueness across codes. Then, I combined codes where there was an overlap. The refined list was applied to all interviews in order to ensure cross case consistency. The variableoriented approach was done once operationalized definitions of the four Subjective Task Values were developed from the initial coding. The operationalized definitions refer to measurable definitions, which are relevant to the study but they correspond to definitions provided in the literature (Burnard, Gill, Stewart, Treasure, \& Chadwick, 2008).

\section{Challenges in translating the research raw data from Khmer into English}

Translating Khmer into English is not an easy task. It requires translation skills and the understanding of the context of what the conversation was about and what exactly the participants had meant in each word and sentence. Also it requires translators to 
carefully choose the English word, which best suits the context. I followed a process of interpretation developed by Larson (1984) in order to have clear, understandable translated transcripts (see figure 3.1).

Figure 3.1. The process of cross-language interpretation

Source language-

Khmer

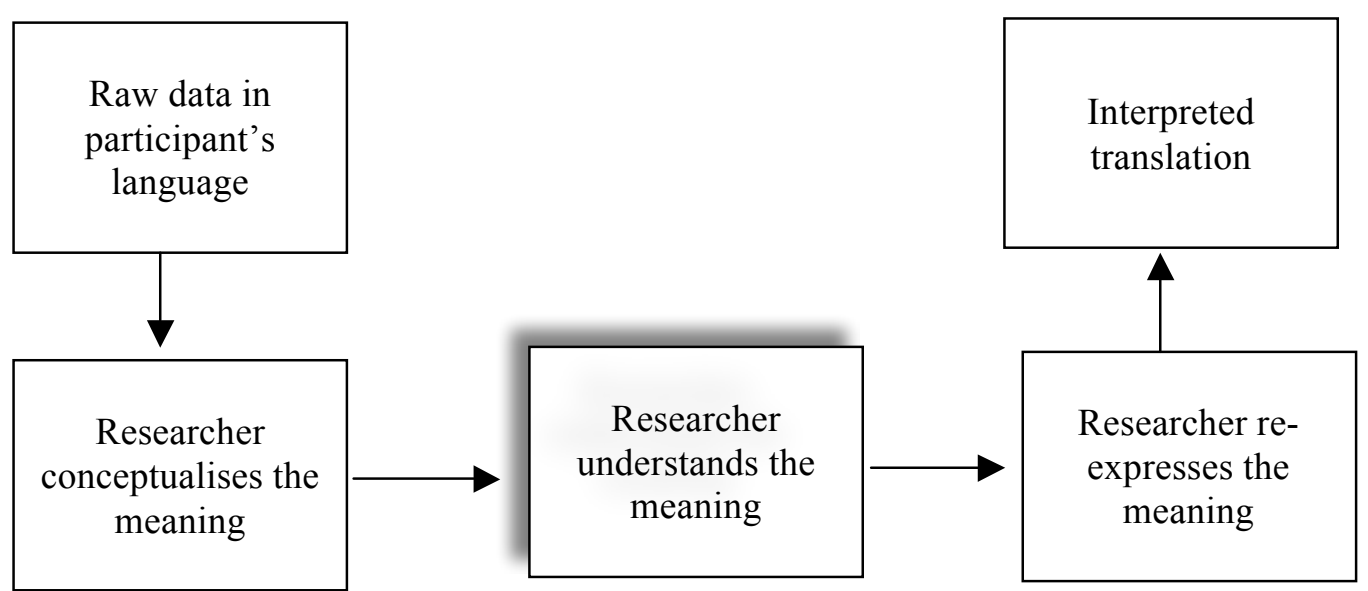

Source: Adapted from Larson $(1984, p .4)$
Target language-

English

Interpreted

translation

meaning

I faced challenges in translating the English interview questions into Khmer and the subsequent Khmer responses to the interviews into English. I found several terms, which were mentioned by the participants that were hard for me to translate into English. For example participant 2 mentioned in Khmer:

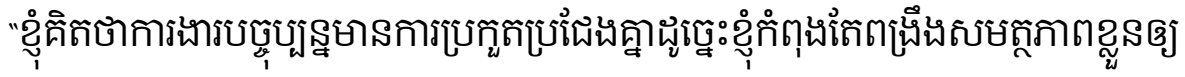

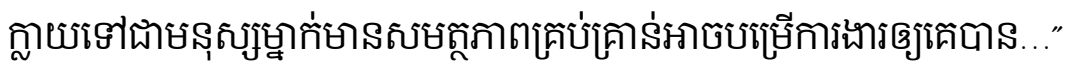

The sentence may mean "I think the competition for a job has been increasing. I am developing my own ability to become a qualified person..." In this case, there are some alternative words, which can be used such as competence, capacity, proficiency, capability or skills. Each word has a slightly different meaning and may alter interpretation of the explanation the participants were providing. 


\section{Trustworthiness}

Member checking is a process when participants check if the interpretation of the interview is correct, and this procedure can reduce the possibility of researcher bias (Johnson \& Christensen, 2008). In this study, the transcripts were initially written in Khmer. I telephoned the student participants to inform them that the transcript of their interview would be sent to them and I asked them to check for accuracy. The participants reviewed their own transcript and sent back any comments they had. Three participants out of the ten sent back the transcripts with some correction. The errors were minor and were corrected before the data analysis began. I telephoned the other participants again to check if they agreed that the transcripts had been correct. Their responses were positive.

This study employed peer debriefing. I discussed the study analysis and interpretation of the data with my supervisor and a postgraduate cohort group to ensure the study's credibility. The cohort group members were three Master's of Education students and a $\mathrm{PhD}$ candidate. All members had been working on tertiary education related topics coordinated by my supervisor. We had a weekly meeting which enabled us to share our challenges and best practices, check literature, share research methodology and discuss research findings. I shared preliminary findings with the cohort group. The group asked provoking questions which helped me find weaknesses in my data analysis and writing. I often had informal talks with Cambodian students who were doing a Master of Education. We shared our fieldwork experiences and often shared our best practices and challenges. I talked about my preliminary findings to get their opinion about their validity. They provided me with helpful ideas and provoked me to look into the data more thoroughly.

I originally planned to hold focus groups with the students to check my emerging findings. Due to constraints of limited fieldwork time in Cambodia, I could not complete the preliminary analysis to prepare emergent findings as planned. I could not arrange a focus group, which had been planned to ensure the trustworthiness of my findings, and the extent to which the participants perceived the findings to reflect their perceptions. Instead, I emailed each participant the summary of their interview, and 
later a summary of the emerging findings for their comments. None of the participants replied to that email. Four responded to a follow-up email but with no comments on the research findings.

\section{Self-reflexivity}

I applied a reflexivity strategy to cope with researcher bias, which is a potential threat to research validity (Johnson \& Christensen, 2008; McMillan, 2008). I prepared a critical self-reflection about my potential biases and predispositions as suggested by Johnson and Christensen (2008).

When I listened to each recorded interview, I realized some things I should have done and should not have done during the interview. I found that I often had not asked probing questions to elicit more detailed stories. I focused more on the prepared questions. It would have been better if I had let the participants talk freely with little interruption.

My interest in this topic began when I made my first decision on postsecondary education in 1999. I wanted to become a high school teacher but I had to take a fouryear programme in Phnom Penh. My family and I decided to choose two-year training in my home province. The main reason was that my parents could not afford my study and living expenses if I was to live away from my family home. Secondly, they did not have close relatives there that I could live with to assuage their worries about my safety. Thirdly, a poor road and shortage of public transport made Battambang very far from Phnom Penh despite its real distance being $291 \mathrm{~km}$. I remembered that it took me 14 hours by train to reach Phnom Penh in 1999. These reasons prevented me from making my own decision to move. I ended up teaching in Battambang more than 10 years.

Moreover, I chose to major in mathematics despite my favourite subject being chemistry because mathematics was considered a more important and popular subject. More importantly, my father really liked this subject and he was a mathematics teacher. 
My interest in this topic increased when I made my second decision at the university where I earned a Bachelor of Business Administration (BBA) in accounting in 2002. I chose accounting not because it was my interest, but there were not many choices at the time I did my degree. My interest major, social development was not offered in any university in my province at that time. I would have had to move to the capital city, Phnom Penh, if I had wanted to major in social development. If I had been able to move to Phnom Penh, I would have moved earlier, following my completion of high school. Then, a question came to my mind: "How did other students choose a major?"

My own experience may affect my research. In order to remind myself not to shape the research finding to fit my experience, I wrote a critical self-reflection and posted it in my study room so that I could keep reminding myself to avoid biases.

\section{Limitations of the research}

Even though care was taken from the beginning to ensure the quality of the research, some potential limitations are acknowledged. First, this is a small qualitative case study of ten first year students majoring in finance and banking in a university in Cambodia. The findings cannot be generalized to other students in the same major or other disciplines. However, it should be noted that this qualitative study did not aim for generalization. If there were more time and resources, a larger sample size might have resulted in richer and wider variations of data.

Secondly, the case study employs in-depth interviews, which enabled the understanding of participants' experiences. However, the participants' explanations may be influenced by some events or challenges during the specific research timeframe. In this study, the interviews were in a classroom arranged by the university and the room was also used for the next class. This time limitation put pressure on both the researcher and participants to finish their interviews and it influenced details of the participants' explanations.

The researcher has a position in the university, where the research was located. Participants were specifically asked not to consider the position of the researcher when participating in the research. However, a few participants treated the researcher in a way, which reflected relative hierarchical positions, which is common in Cambodian 
culture.

Two participants were so nervous it was as if they were in an oral test. The situation was better after the researcher set up a friendly environment. However, participants' nerves may have limited their ability to share.

Translation from Khmer to English and vice versa was challenging. The interviews were conducted in Khmer. The initial transcripts were in Khmer and translated into English for coding. Translation may have led to misinterpretations when participants and translators have different perspectives and experiences.

\section{Summary of the chapter}

This chapter covered the research design of the study, research setting, characteristics of the participants and recruitment, ethical considerations, data collection procedures, methods and tools, data analysis and trustworthiness of the research. The challenges of transcribing and translating data from Khmer to English were also discussed. 


\section{Chapter Four: Findings and descriptions of individual cases}

This chapter presents findings from the interviews with the 10 participants. The current study addressed the questions: (1) How do students' beliefs contribute to their choice of major in their degree? (2) What influences students' future career plans? In answering these questions, the findings are presented in two phases. Firstly, findings from within-case analysis are elaborated. Findings from cross-case analysis among the 10 cases will be discussed in the following chapter.

This section describes findings from the 10 interviews using within-case analysis. Each case was analysed individually. Important emerging themes were assigned as subheadings in each case. These themes include expectancy, self-efficacy, interests, future goals, future expectations, costs (e.g., effort, time, sacrifices, and expenditure), quality, time and location, key influencers, information sources, and future career plans. A summary diagram of each participant's motivation to choose a major was developed. This diagram was formed with the consideration of the expectancy-value theory.

After coding the 10 interviews, a final list of codes was developed and described in the methodology chapter. Table 4.1 sets out the final code list accompanied by definitions of the key constructs (based on Eccles, 2009) as well as the operationalized definitions used in this study, and examples provided for each construct as evidenced in the research findings.

Recalling major constructs in expectancy-value theory (Eccles, 2009; Eccles \& Wigfield, 1995; Wigfield \& Eccles, 1992) introduced in Chapter 2, in the current study, expectancy means students' beliefs in their ability to complete a business degree. Attainment value means a reason for doing finance and banking is related to sense of self (e.g., "good at maths"). Cost represents making sacrifices to become finance and banking staff. Interest means enjoyment of finance-banking related activities. The last construct is utility, which refers to expected usefulness of finance and banking in the future career. 
Table 4.1. Definitions and example of final codes in the current study

\begin{tabular}{|l|l|l|l|}
\hline Codes & $\begin{array}{l}\text { Eccles (2009) } \\
\text { Definition }\end{array}$ & $\begin{array}{l}\text { Operationalized } \\
\text { Definition }\end{array}$ & Example \\
\hline Expectancy & $\begin{array}{l}\text { An individual's belief in } \\
\text { the possibility of their } \\
\text { success in business. }\end{array}$ & $\begin{array}{l}\text { Beliefs in completing a } \\
\text { business degree } \\
\text { successfully. }\end{array}$ & $\begin{array}{l}\text { I am confident to } \\
\text { successfully earn a } \\
\text { business degree and } \\
\text { become a } \\
\text { businessperson. }\end{array}$ \\
\hline Attainment & $\begin{array}{l}\text { The expected } \\
\text { importance of doing } \\
\text { well in a task in terms of } \\
\text { an individual's key } \\
\text { personal values. }\end{array}$ & $\begin{array}{l}\text { A reason for doing } \\
\text { finance and banking } \\
\text { related to having the } \\
\text { necessary skills for } \\
\text { learning finance well, and } \\
\text { being the type of person } \\
\text { who works in finance and } \\
\text { banking. }\end{array}$ & $\begin{array}{l}\text { I am good at maths, } \\
\text { and numbers and I } \\
\text { think these skills will } \\
\text { be important for when } \\
\text { I work at a bank. }\end{array}$ \\
\hline Interest & $\begin{array}{l}\text { The interest of a person } \\
\text { in engaging in an } \\
\text { activity. }\end{array}$ & $\begin{array}{l}\text { The enjoyment of } \\
\text { studying finance and } \\
\text { banking or working in a } \\
\text { bank in the future. }\end{array}$ & $\begin{array}{l}\text { I like learning finance } \\
\text { and banking and I have } \\
\text { liked this major since I } \\
\text { was in grade 10. }\end{array}$ \\
\hline $\begin{array}{l}\text { The usefulness of } \\
\text { engaging in a task to } \\
\text { reach one's short-and } \\
\text { long-term goals. }\end{array}$ & $\begin{array}{l}\text { The perceived usefulness } \\
\text { of a business degree for } \\
\text { short-and long-term goals } \\
\text { including being employed } \\
\text { by a bank. }\end{array}$ & $\begin{array}{l}\text { I chose finance and } \\
\text { banking because I } \\
\text { want to get a job at a } \\
\text { sank with a good } \\
\text { success. }\end{array}$ \\
\hline salary.
\end{tabular}

Source: Adapted from Matusovich et al. (2010, p.294)

The 10 cases are presented in the following section. 


\section{Case one: Mony}

Twenty-one year old Mony's mother is a farmer and his father is a soldier. His family encouraged him to pursue a higher education. He is the first person in the family to go to university. His elder brother and younger sister dropped out before high school as they thought they were not good at studying. His elder brother helps his mother on the farm. Mony initially enrolled in English literature at a private university but the university discontinued that course due to insufficient students. He then enrolled in a finance and banking major.

Mony sees himself as different from other members of his family in that he likes studying. Because he is a hard-working student, his parents are supporting him financially at university. However, he is not totally dependent on his parents as he has three part-time jobs. He is a receptionist at a hotel, an English teacher at an institute and a part-time staff member for a local non-governmental organization.

Mony is one of the three participants not living at home. He is comfortable living away from his parents. Mony is an independent person. He expressed his independence in the way he talked and his level of certainty about his decisions and future plans. He does not want to live with his family after he graduates. He expects to be involved in politics and that there will be some problems and he does not want his family to face these problems. He prefers an independent life.

\section{Reasons for the choice of major}

\section{a. Expectancy}

Mony is confident that he will graduate with a finance and banking degree. That his level of confidence is high was demonstrated by the clarity of his longer-term plans.

\section{b. Attainment}

Mony chose finance and banking because he recognised his own ability in subjects, which are necessary for doing finance and banking such as mathematics. Mony said "Maths was my high school favourite subject. I like number-related subjects including maths, chemistry, and physics." 


\section{Perseverance}

He believes that his perseverance and abilities will lead to achievement as he said"I am a hard-working student... I like studying."

\section{c. Interests}

Mony's choice of a major was clearly related to his interest in the major. He enjoys studying finance and banking. He talked enthusiastically about learning finance and banking:"It's the major I like the most...I like my study as it is my interest."

\section{d. Future expectations}

\section{Future employment}

Employment prospects played an important role in Mony's choice. Mony chose finance and banking because he wants to get a job after graduation, and thinks there will be employment opportunities in this field. He plans to start working for a bank while at university in order to get experience, and he expects that after graduation, he will take up an offer from his father's friend to work as a financial officer. Mony, who has political aspirations, was the only participant who mentioned that his future work, in the finance and banking industry, would contribute to the development of Cambodia.

\section{Labour market}

The choice of major is likely to be influenced by expectations or perceptions of job availability (Malgwi et al., 2005). Mony believes that there will be more banks and additional investment in banking in Cambodia. He expects the labour market to expand despite being aware of increased job competition.

\section{e. Key influencers}

People who significantly influenced Mony in his decision making were his family, schoolteachers and academic staff at the Provincial Office of Education, Youth, and Sports (POE). 


\section{Influence of family}

Mony's family members including his mother, father, and siblings were actively involved in the decision-making process as to which major he should choose. They provided both support for, and disagreement with, the choice of finance and banking. His siblings encouraged him to choose finance and banking. Mony's mother was a significant influence in his choice of a major. She constituted a "pull factor" in the choice of finance and banking. She was actively involved in the decision-making process and provided financial support for Mony to do this degree.

Like the majority of Cambodians, Mony's mother is a farmer. She owns a mediumsized area of land for planting crops such as corn and rice. Farming in Cambodia is labour-intensive because few farmers can afford expensive machinery. This is particularly true for subsistence farmers. Typically productivity depends on nature, and the vagaries of weather (e.g., flooding and drought). There are not enough irrigation systems in Cambodia, and this adds to the workload and stress. Mony's mother's education and career may have influenced her position of not wanting her child to work on a farm. This was the likely reason she supported the choice of the finance and banking major, which appeared to offer her child the prospect of a good job.

On the other hand, Mony's father opposed his choice. He produced a "push force" trying to persuade Mony to major in law rather than in finance and banking. Mony's father preferred law and his opposition may have been related to his occupation. His father is a soldier, a job, which in Cambodia is closely related to law. However, it should be noted that Mony had a clear and strong determination to pursue his chosen path. He chose finance and banking even though his father did not financially support his study. Mony said that "I explained to my dad that I wanted to major in finance and banking because I prefer it to law... Then my dad agreed and allowed me to learn whatever I wanted.” 


\section{Influence of teachers and school}

Mony sought guidance from a former teacher who worked for the provincial office of education. This teacher encouraged Mony to complete a finance and banking degree. This encouragement made Mony more confident in his choice.

While his school principal was not directly involved in the decision-making process, he supported Mony's decision to go to university. He encouraged Mony's parents to allow him to go on to higher education. "Because I am a hard-working student, the director of my Lower Secondary School encouraged my parents to support me for higher education."

\section{f. Information sources}

Mony came to know about finance and banking and employment prospects in that industry from a staff member of the POE and from his father's friend who worked at management level in a government department.

\section{g. Future career plans}

Mony planned his future life and career before he chose a major. First, he wanted to get a job related to his major. Then, he intended to be involved in politics. His plan appears realistic, as when interviewed he had already started applying for jobs with banks. He had already joined a political party and formed political networks. Mony also plans to do a master's degree and start his own family. As Mony said, "choosing finance and banking is in accordance with my goals. My main goal is to graduate with a degree in finance and banking."

\section{Why not other majors?}

Mony's father, a soldier, encouraged Mony to choose law because he believed that law is important in every society. Mony did not follow his father's advice and discussed his reasons for not doing so. Firstly, Mony did not like rote learning, which he associated with studying law. He preferred subjects such as maths and science. Mony said "I prefer finance and banking to law because I don't like learning by heart. I prefer numbers and science."Secondly, he was not interested in law but was interested in finance and banking and lastly he lacked confidence in his ability to study law. 
As mentioned, Mony studied English literature for a year until the course was terminated. He decided not to choose this major again because he had become focused on future employment. He preferred working in a bank to teaching. A summary of how Mony came to choose finance and banking is shown in the diagram below.

Figure 4.1. Factors that influenced Mony's choice of major

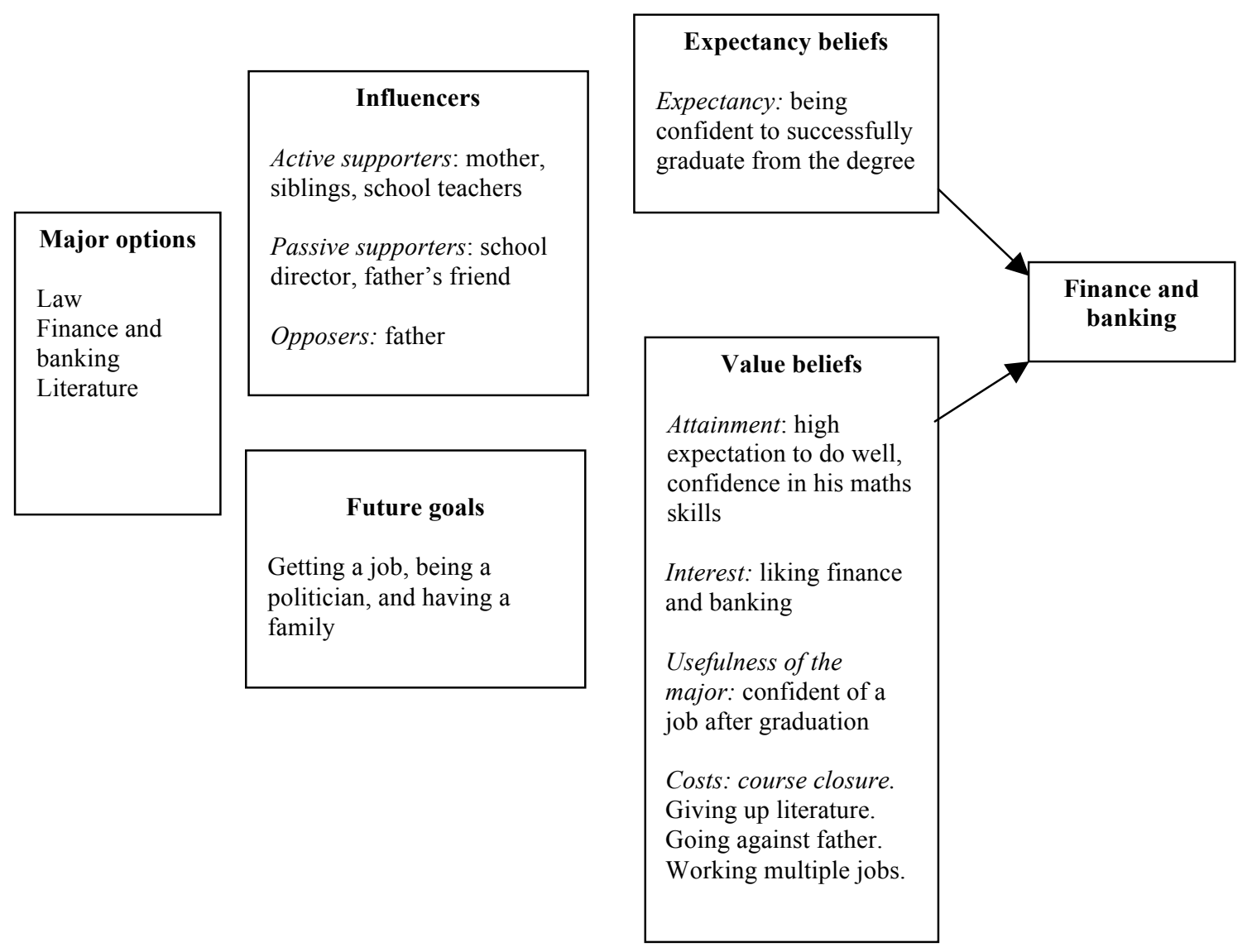




\section{Case two: Chamnab}

Twenty-year old Chamnab is from a suburb of Battambang. His father is a farmer and his mother a grocery vendor. His parents provide financial support for Chamnab and his seven siblings' education. His elder sister and elder brother are also majoring in business at the university. Coming from a large family, Chamnab had to make his decision carefully and to consider costs. He chose not to pursue his first choice of a major, information technology (IT) because it required him to live in the capital city where expenses would be higher.

Chamnab is an emotional person who values love and family. He initially enrolled in the tourism majorat university because he wanted to study with his girlfriend, not because he was interested in tourism. Chamnab does not want to live or work away from his family. In the interview he struggled to describe his own interests and individual identity. Family members, his girlfriend and friends played a significant role in his choice of a major.

\section{Motivation to choose finance and banking}

\section{a. Expectancy}

After moving out of the tourism major, he decided to major in finance and banking. He expects to be successful in this degree.

\section{b. Attainment}

Chamnab expressed his choice in relation to his capabilities. For example, he chose not to study English literature or tourism because he was not good at English or history. He chose finance and banking because his maths skills were good.

\section{c. Interests}

Enjoying the major helped Chamnab persist with the degree despite experiencing course difficulties, and his friends' attempts to persuade him to change major. He had changed his major once before but found that he did not like the tourism course content and he realized that it was not a field that interested him. He likes his finance and banking class and loves the idea of working at a bank. 


\section{d. Future expectations}

Potential earning income

Chamnab's choice was made based on the expectation of getting a good job with a good salary at a bank or with micro-finance institute. He plans to earn money and save it for his future plan.

\section{Employment}

Employment prospects were a major factor in Chamnab's choice of major. He expects to get a job at a bank because he believes that the labour market of finance and banking will expand and be broader than the IT labour market because of the expectation for growth in investment. He expects to work in an office because he chose finance and banking.

Perceived work conditions played a role in Chamnab's decision. He likes office work. He did not choose other alternative majors because he did not like the expected work conditions. He made a choice not to study tourism because he thought that it would require him to travel and he does not like travelling.

Chamnab believed that working at a bank is socially valued. Cambodians value banking-related jobs as they are directly related to money and are office jobs for which staff are able to wear nice uniforms.

\section{e. Cost and quality}

Chamnab considered cost, quality, and distance in making his study decisions. For instance, with the consideration of quality, he preferred doing IT in Phnom Penh, the capital city of Cambodia, rather than Battambang. However, moving to Phnom Penh would have resulted in higher living expenses. He decided to choose a major with lower expenses. Chamnab explained:

I think IT has a smaller labour market. Also, I think that if I study IT, I should do it in Phnom Penh... I think learning IT in Phnom Penh is better than in Battambang. However, I don't have any relatives there and learning in Phnom Penh would cost much more than learning here. 


\section{f. Key influencers}

Key influencers including siblings, parents, and friends shaped Chamnab's choice of a major.

\section{Influence of family}

Chamnab is different from the other male participants. He was the only male participant who openly talked about his close relationship with his family. Family ties were an important consideration for him. He would not want to choose a major or career, which might require him to live away from his family. He said the following:

\footnotetext{
My first choice is to work and live with my family...I did not like tourism because I think working in tourism I might need to travel a lot especially I will be away from my family or I may work in other provinces or cities. I don't want to live far from my family. It's not because my parents are old, but it's because I have never lived away from my family.
}

Chamnab's siblings who are enrolled in higher education had a significant influence on his decision making. His elder brothers and sisters actively contributed to his decision making. They provided information on the business degree and the associated job market. He discussed options with his elder sister who was a fourth year accounting student.

Chamnab's father has been a rice farmer for three decades. He was happy to support whatever major Chamnab chose. He did not want Chamnab to work in agriculture because he believed the work was too hard. His parents encouraged him to choose finance and banking and they have been contributing financially to his study.

\section{Influence of peers}

Peer influence was both a push and pull factor in Chamnab's decision. It should be noted that Chamnab was enrolled in tourism before changing to finance and banking. He took tourism because he wanted to study with his girlfriend. The influence was significant in this case.

It was important to Chamnbab to please his friends and he was susceptible to peer pressure. Chamnab reported that his friends doing different majors tried to persuade him to choose the same degree as theirs. Some friends asked him to change back to 
tourism in his second year. However, other friends majoring in finance and banking encouraged him to persist with that degree. Although he attributed his decisions to the influence of others with time his decision on the major became his own, and he was committed to persist with this major.

\section{Information sources}

Chamnab reported that he heard news about the business labour market and the growth of the banks on radio and newspaper. He also received advice from his elder brothers but mainly from an elder sister who is an accountant.

\section{Future career plans}

Chamnab plans to have an office position at a bank or in micro-finance. His longer plan is to run his own business. He said his parents offered him their house to start his business in the future. See Figure 4.2 for summary of how Chamnab chose finance and banking. 
Figure 4.2. Factors that influenced Chamnab's choice of major

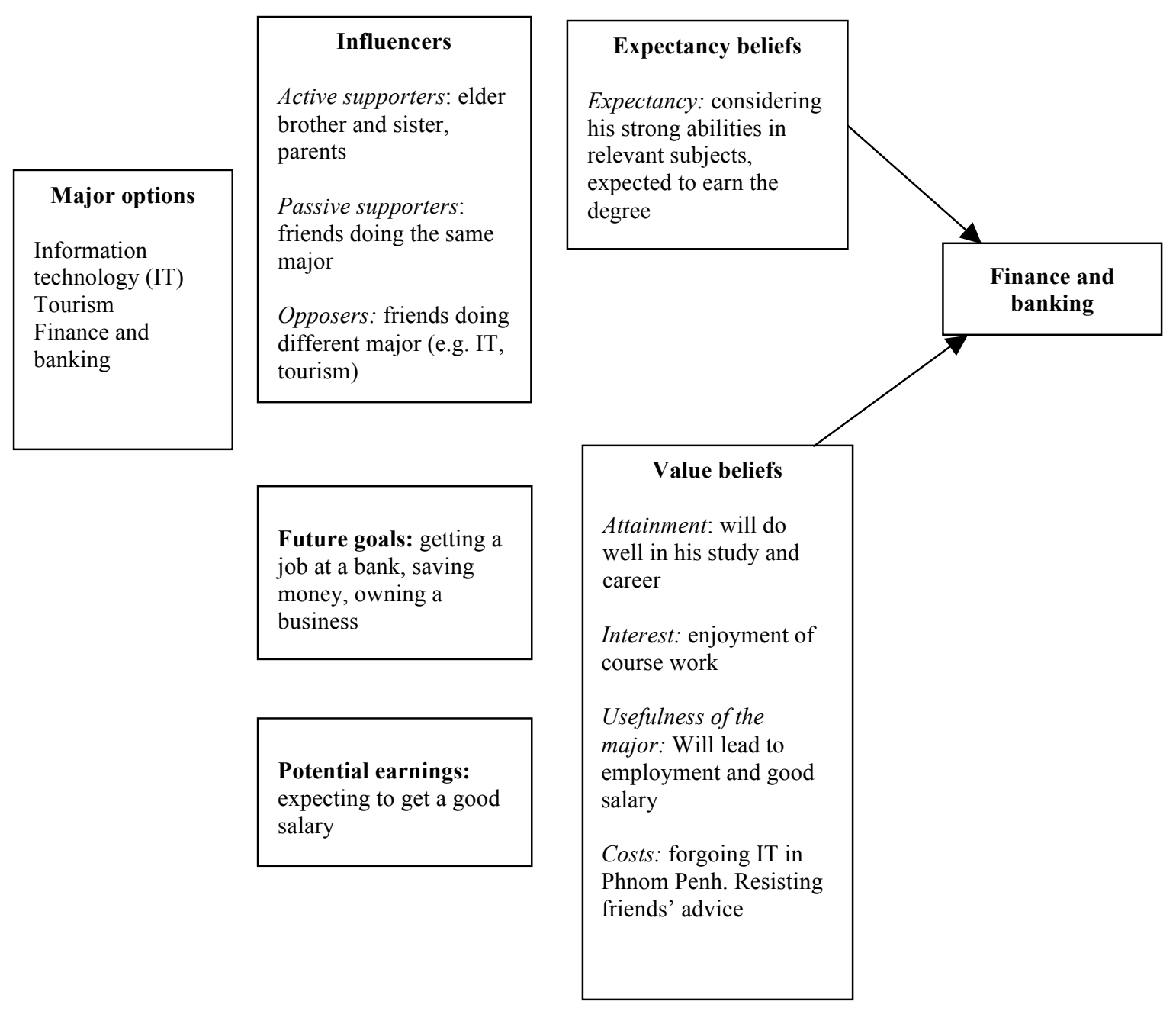




\section{Case three: Sophy}

Nineteen-year old Sophy is from a province some distance from Battambang and closer to Phnom Penh. Her mother is a teacher and her father a farmer. She has one younger brother. Sophy is one of four students not living at home. She is living with her uncle. She would prefer to live with her parents. She did not go to Phnom Penh because she has no relatives there. Her decision to choose a major was associated with culture and the perception that security is important for a girl.

\section{Motivation/reasons for choice of major}

\section{a. Expectancy}

Sophy was committed to her choice of major. After she chose finance and banking, Sophy became determined to earn this degree and not to change the major even though some of her friends have tried to persuade her to change. She believes that she can complete this degree and get a job at a bank in the future.

\section{b. Attainment}

Interestingly Sophy likes maths even though she is not very good at it. She is not confident that she will receive good grades. However, she is studying hard.

\section{c. Interests}

Sophy is satisfied with her choice. She loves the major, and has enjoyed learning. She was interested in finance and banking long before she entered university. She chose finance and banking when she applied for the scholarship, while she was still at high school. "I love this major... I was interested in these two majors: finance and banking, and medical doctor... I prefer finance and banking to marketing"

\section{d. Future expectations}

\section{Employment}

Like other participants, Sophy expects the number of banks in Cambodia to grow and that there will be more investment in the future.

\section{Work conditions}


The expected working conditions were integral to her decision. Sophy loves the idea of working at a bank as it is office work with air-conditioned rooms. She wants to wear a nice uniform. Sophy has envied staff in banks as she said, "Frankly speaking, I saw bank staff wearing beautiful uniforms and working in an air-con room."

\section{Potential earning income}

Sophy valued work conditions more than remuneration as she said "Even though the salary of a bank staff is not very high, I love this job."

\section{e. Cost and time}

Sophy's first choice was medical school. However, such a major takes a long time (seven years for a medical doctor and ten years for a specialized doctor). Moreover, doing a medical degree is more expensive than her family could afford. It is one of the most expensive degrees in Cambodia.

\section{f. Key influencers}

\section{Influence of family}

Although Sophy claimed her parents were happy for her to choose whatever she wanted to study, it appeared that her mother was the key decision maker. Her mother's influence was more significant than her father's as she did not mention her father in discussion about the decision-making process. Her mother decided to send her to Battambang so that she could stay with her uncle. Sophy stated that "My mom thought that her brother... She thought it was better for me to be with relatives rather than with no one in Phnom Penh."

Her parents are meeting the cost of her study. The decision involved further relatives. Her uncle who works at a bank played an important role in her decision making. His advice encouraged Sophy to choose finance and banking.

\section{Cultural influence: Security and location}

Sophy and her parents considered the question of security if Sophy was to study away from home. Male participants who live far away from their family did not raise this concern. The concern of security when living far away from family represents a cultural difference between the attitudes to males and females in Cambodian society. Her final decision about where she would study was made by her mother. 
Influence of high school teachers

Before Sophy's decision was made, she asked for suggestions from her high school teachers. These teachers confirmed that finance and banking was a sensible choice.

\section{Influence of peers and neighbours}

Sophy's neighbours and friends who are doing different majors were not actively involved in the decision-making process. However, they supported the choice and encouraged her to choose the major.

\section{Information on the major and its market}

Sophy did not identify many information sources relevant to the business degree. Her main source of information was an uncle who worked at a bank, and high school teachers. She tended to trust these people. Although she is happy with her choice of major, looking back she thinks she did not have sufficient information about employment prospects in making her decision. Sophy talked about how she got the information:

I haven't got clear information. However, my uncle who works at ACLEDA bank told me that the banking sector is booming in Cambodia. Some of my high school teachers talked a little bit about the Cambodian labour market.

\section{Future career plan}

Sophy plans to work at a bank. It is her ideal job and she dreams of working in an office and wearing a beautiful uniform. See Figure 4.3 for summary of how Sophy chose finance and banking. 
Figure 4.3. Factors that influenced Sophy's choice of major

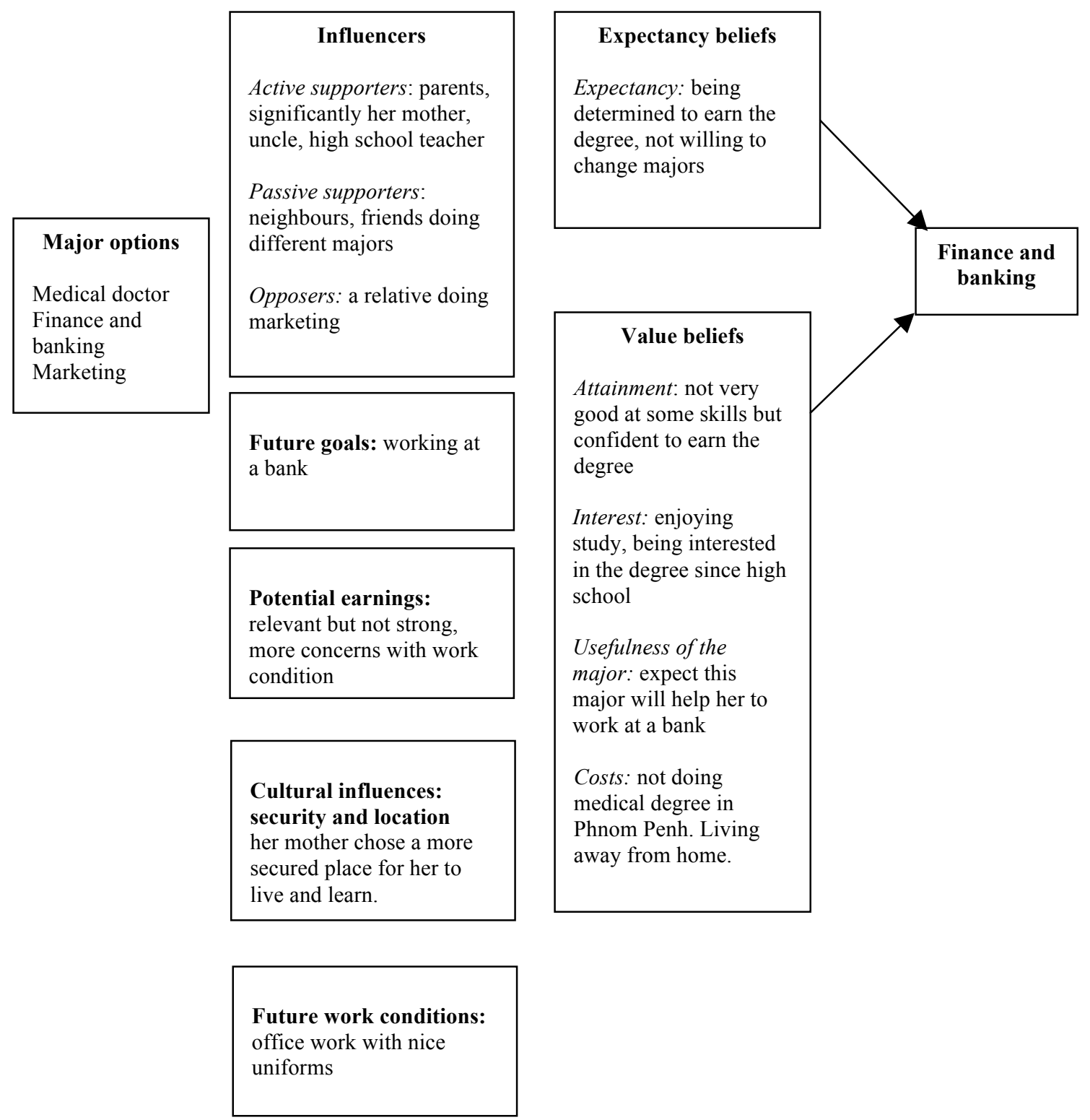




\section{Case four: Mara}

Mara is 24 years old and comes from a district in Battambang. He has an elder sister and a younger brother. His parents are farmers and could not afford the university fees for both his elder sister and him to do the degree at the same time. His elder sister started university first. Luckily, Mara won a scholarship to study management at a local institute. Unfortunately, the institute went bankrupt when he was in his third year. He could not obtain his academic record so he had to enroll in a new major from the first year. His elder sister is in her fourth year. She has a job and now pays Mara's university fees. Mara acknowledged that he needs to improve his self-confidence especially when he is working with customers at his volunteering job.

\section{Motivation to choose finance and banking}

\section{a. Expectancy}

Mara is confident that he will finish his degree. He believes that if he studies hard, he will get a job after graduation. It should be noted that he decided not to major in management, which he had studied for three years. He had found management difficult and he did not feel confident to successfully complete a management degree. However, he is confident that he will complete the finance and banking degree.

\section{b. Attainment}

Mara believed in his ability to be successful with his business studies because he is good at maths, chemistry, biology, and economic analysis. His confidence in his ability with maths and calculations gives him confidence of success in finance and banking.

\section{b. Interests}

Mara prefers finance and banking to other subjects. He does not plan to change his major again. He loves studying courses such as economic analysis and maths. He chose against majors such as law and tourism because he was not interested in learning theories. Mara said:

Hmm... There were some other majors such as marketing, tourism, and accounting. I like finance and banking the most. Also, as I like chemistry and biology, I took the exam to be a nurse but I failed the exam. 


\section{c. Future expectations}

\section{Employment}

Mara believed that finance and banking offered more job choices than other majors including accounting. With finance and banking means he would be able to work as a finance officer, accountant or in a bank. He expects that the labour market in banking will grow quickly in the near future.

He decided to stop studying management because he did not expect to be able to get a job in management after graduation. Moreover, he believed that he would not be able to manage a business right after graduation. Therefore, he decided to major in finance and banking.

\section{Usefulness of the major}

Mara believed that his choice of major would be useful for his future. Seeing the advantages of the major was a factor in his decision making. He stated that:

What I have learned in this year is very useful, for example, I took a paper on micro and macroeconomics. This paper enables me to understand more how it links to business. Another example is maths. It's useful for a business.

\section{Potential income}

For Mara, expected income was a vital aspect to consider for his next goal: owning a business. He expects to get a good income from his job and business. He said:

I know that running a business is risky. However, if it is successful, I can get higher income than working for others... If I don't have enough capital, I should work for others first and save money for starting my business. 


\section{d. Key influencers}

\section{Influence of family}

The major person involved in his decision making was his elder sister who works for a micro-finance institute. His parents were not involved, but they agreed with his choice. His elder sister financially supports his choice because his parents could not support him.

\section{Influence of high school teachers}

Mara sought advice from his high school teachers before he enrolled in finance and banking. The teachers were positive about the finance and banking major and career prospects from such a major.

\section{Influence of peers}

Friends doing different majors tried to persuade him to choose different majors such as law. However, their influence was not significant in his decision-making process.

\section{Future career plans}

Mara chose finance and banking as a step toward his long-term goal to own a business. Mara has clear goals, to be employed, save money and to run his own business. He planned his career path before he enrolled in finance and banking. In addition to studying he volunteers for a non-governmental organization, which runs a small business for sustainability. Mara is preparing for his future through improving his skills and knowledge, such as business strategies and customer service, for his future career and goals. Mara said:

My long-term goal is not working at a bank. I wish to run my own business once I have enough money... I am now studying about the business market. I am volunteering for a non-governmental organization, which is running a small business... I hope my work experience and customer service skills will help my future business. 
A summary of how Mara chose finance and banking is shown in the following diagram.

Figure4.4. Factors that influenced Mara's choice of major

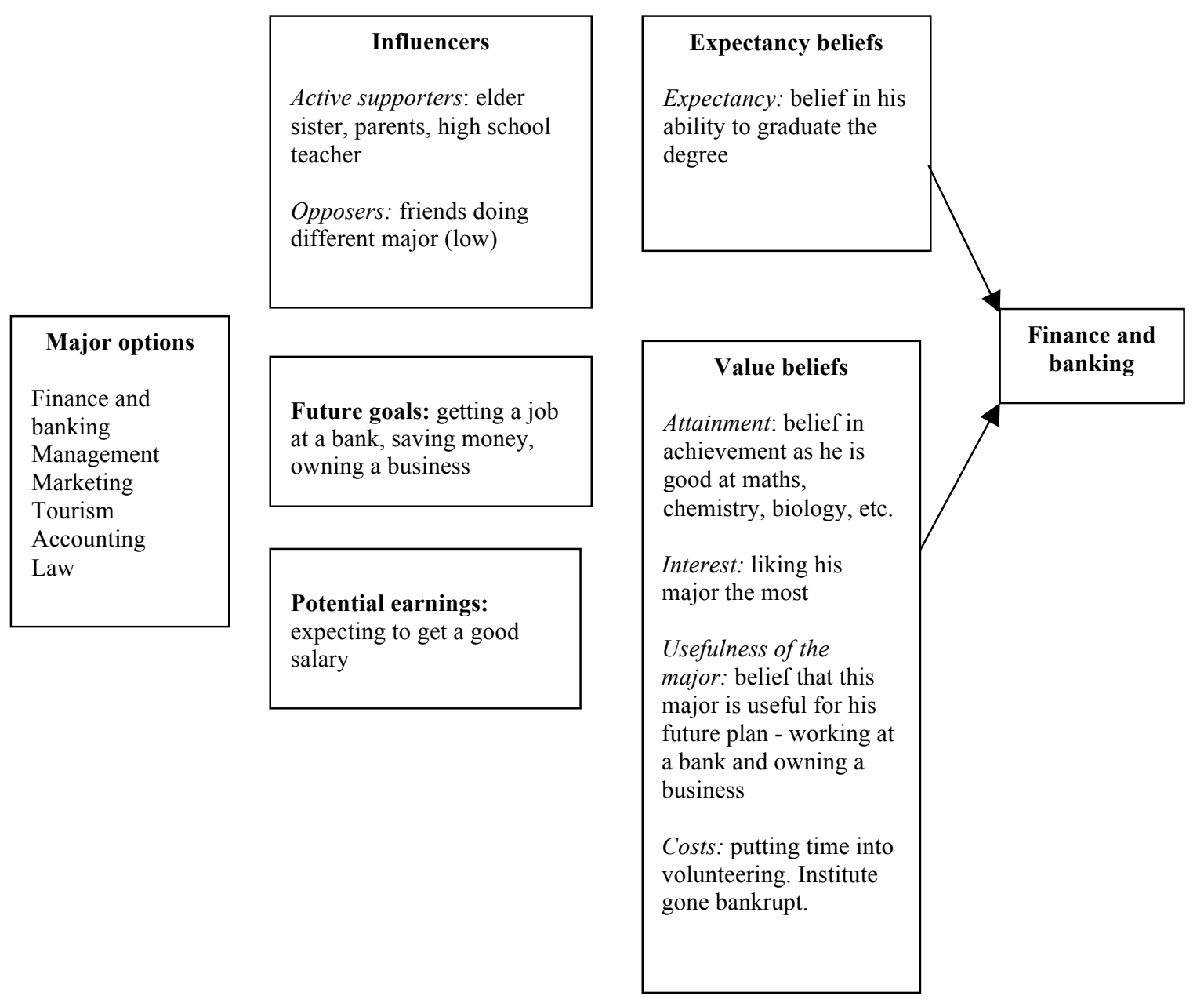




\section{Case five: Boeb}

Boeb is a 22 year old student whose father has passed away and whose mother stays at home. He has eight siblings and he lives with his mother, elder sister and her family in the central city. His elder sister financially supports the whole family. In his family, only he and his two younger brothers go to school. He has the highest education. He firstly became interested in finance and banking when he read an English book about a bank manager. He would like to be a financial officer when he graduates and he will work hard to be promoted to a bank manager. Boeb is currently working as a waiter at a restaurant to help cover his living expenses.

\section{Motivation to choose finance and banking}

\section{a. Expectancy}

Boeb chose finance and banking even though he was not confident about his ability to compete for a job. He believes that if he studies hard, he will be able to get a job. He has struggled with some difficult subjects but he is sure that he will not give up his chosen major. Boeb said "what I am worried about is the competition for a job. I'm not confident in this competition. So I need to study hard."

\section{b. Interests}

Boeb's interest in finance and banking was significant. He liked this major. He also liked some other majors such as Law, English literature and veterinary science. However, finance and banking was his most favoured subject.

\section{c. Future expectations}

\section{Employment}

With encouragement from his relatives and friends, he expects to get a job at a bank or a company. He was worried about the competition for a job. However, he has been preparing for this competition. 


\section{Work conditions}

Working conditions are also important for Boeb. He loves office work as he said, "I like working in an office, for example information desk and research."

\section{d. Usefulness of the major}

Boeb expects that what he has learned from finance and banking will help him in searching for a job in the future. He believes that what he has been learning will be applicable in his future job.

\section{e. Cost, quality and locations}

As mentioned earlier, Boeb is interested in law. However, the cost of a law degree and related living expenses meant that he was unable to pursue a law degree. He preferred not to study law in Battambang, because he thought that the course quality provided in Phnom Penh would be better. His family could not support his study and living expenses in Phnom Penh. So he chose finance and banking in Battambang.

\section{f. Key influencers}

\section{Extended family}

No one opposed his decision. People who were actively involved in his decisionmaking process included his aunt who worked for the Provincial Treasury Office, and his brother-in-law who worked for a private company. His elder sister who supports him financially was the most influential as the final decision required her support. For instance, she did not allow him to do law in Phnom Penh because she could not afford the expenses, and Boeb had to follow. Boeb said "My elder sisters didn't allow me to go to Phnom Penh. I think my family could not support me to do law. "His mother agreed with whatever he chose. She does not know much about the labour market and is not the decision-maker in the family. 
Peer influence

He searched for advice from people who had worked or studied in a relevant area. His friends who were doing the same degree encouraged him to major in finance and banking.

\section{Information sources}

Boeb did not refer to any other information sources besides his aunt, brother-in-law and friends. He tended to trust that the information they provided was relevant to the business labour market.

\section{Future plans}

Boeb's choice of major was relevant to his future goal: being a bank manager. He has thought about being a bank manager since he was in grade 9. His goal had led him to choose this major and he believes that his choice of major will enable him to achieve his goal. He has prepared for his future. He is now improving some essential skills such as English and computer skills. He said the following:

Because I like finance and banking, I would like to be a financial officer at a bank or a company. I am currently interested in a position- a teller at a bank. My longterm goal is to be a bank manager. 
A summary of how Boeb chose finance and banking is shown in the diagram below.

\section{Figure 4.5. Factors that influenced Boeb's choice of major}

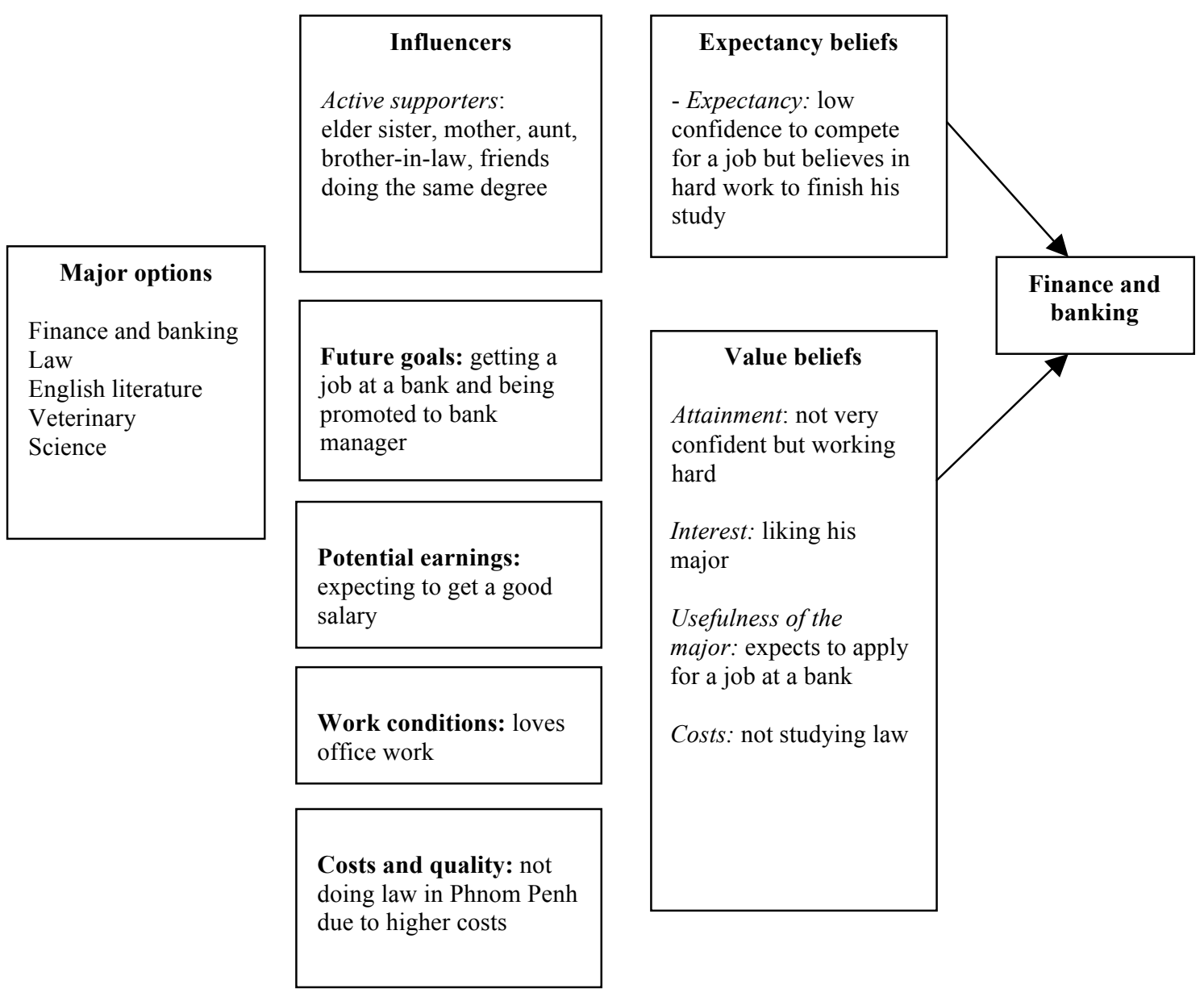




\section{Case six: Navy}

Navy is an 18 year old girl from the city centre. Her father works at the railway station and her mother stays at home. Her father finished primary school whereas her mother finished high school. Navy initially enrolled in law in Phnom Penh. Then, her family asked her to come back to Battambang. She then enrolled in finance and banking. She was the only participant planning to change her major. In the coming year, she plans to change to accounting. Her uncle was actively involved in the decision to change her major.

\section{Motivation to study finance and banking}

\section{a. Expectancy}

Navy does not expect to complete a finance and banking degree. She plans to change her major. Instead she expects to graduate with an accounting degree.

\section{b. Interests}

Navy chose finance and banking because she likes numbers and learning maths. She is interested in working with numbers. One reason she dropped out of law was because she did not like remembering theories. It is important to note that she became less interested in finance and banking. So she has decided to change her major to accounting in the coming year.

\section{c. Future expectations}

\section{Employment}

The most significant factor in Navy's decision making was her expectation of employment. She plans to change from finance and banking to accounting because she believes that the accounting labour market is bigger. She now wants to be an accountant. She said "I want to change my major into accounting after I finish my first year. I believe that if I learn accounting, I can work for a bank and other companies."

\section{Potential income earning}

One of the main reasons for Navy to choose a major is projected income. She wants to get a good salary as she said, "I want to get a job with a good salary to support myself and my family... I expect to get a monthly salary between 300 and 500 US Dollars.” 


\section{d. Relevance with expenses and location}

One interesting thing about Navy is that she had changed her major twice for a variety of reasons. The critical factors for these changes were the cost of the major, the location to do the major, the comparative quality of the major, relevant expenses, essential study skills, and job opportunities. Initially she thought that doing law in Phnom Penh was better than in Battambang. However, the expenses were too high. She changed to a major in finance and banking which was comparatively cheaper and she could live with her family. Navy stated that:

I quit my study in law in Phnom Penh... because my family couldn't support the high expenses... I turned to finance and banking because I like maths and the cost was reasonable.

\section{e. Key influencers}

\section{Influence of family}

Navy's parents were involved in her decision making and they covered her school fees. They asked her to drop out from her first choice in law, which required her to study in Phnom Penh. Her mother, who had a higher level of education, was more influential than her father in the decision. She said the following:

In fact, I went to Phnom Penh and learned law for a month there. I quit it and came back to Battambang because my family couldn't support this high expense... My dad encouraged me to do both degrees-law and finance and banking, but my mother rejected the idea. She wants me to choose an exact major.

Navy's uncle who is in his fourth year of finance and banking played a key role in Navy's decision to change from finance and banking to accounting. Her uncle persuaded her to study accounting because he believed that accounting had more job opportunities in comparison to finance and banking. Navy agreed to change her major in the next academic year. She talked to her relatives and they supported this change. 


\section{Influence of a high school teacher}

Before she decided to change from her current major, she discussed this with her high school teacher. The teacher agreed accounting was a better choice and encouraged her to major in accounting.

\section{Information sources}

Navy did not mention any formal sources of information on majors. Her only information on the business labour market was from her uncle.

\section{Future plans}

Navy plans to get a job and earn a good salary. She would like to be an accountant.

A summary of how Navy chose finance and banking is shown in the diagram below.

Figure 4.6. Factors that influenced Navy's choice of major

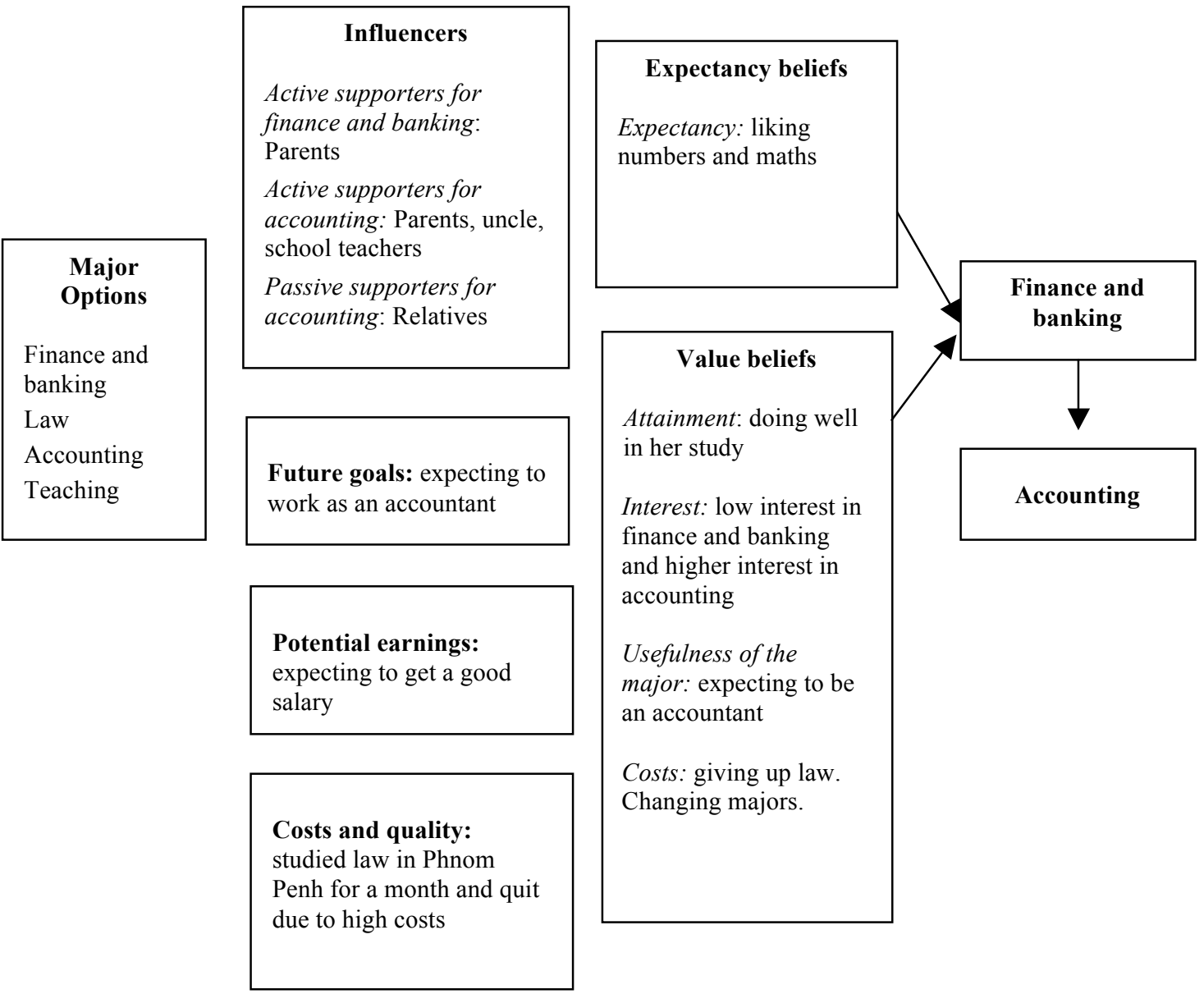




\section{Case seven: Sam}

Sam is 19 years old, and from a neighbouring province to Battambang Province. He has four siblings. His parents are farmers. They plant crops such as corn. He was not interested in agriculture. He prefers office work to farm work. He had two majors to choose between before his enrolment: finance and banking and law. Sam was the only participant who lived independently in rented accommodation.

\section{Motivation to learn finance and banking}

\section{a. Expectancy}

Sam joined a study group to improve his maths skills. This group has helped him gain the confidence to complete a finance and banking degree and to get a job at a bank.

\section{b. Attainment}

Sam almost gave up finance and banking because he felt he did not have the skills for this major. The study group helped him to learn better, especially maths. He became confident about his ability to learn. He said:

When I had studied for one semester, I thought this major was so difficult especially maths and philosophy and I wanted to change my major to study law. However, I changed my mind not to quit studying finance and banking after I joined a study group discussion. The group work helped me to learn maths and exercises better.

\section{Perseverance}

Sam expressed his determination to study finance and banking as he said,"I am determined to study harder next year."He has been working hard as he joined a study group to improve his study.

\section{c. Interest}

Sam's interest in learning finance and banking increased after he joined the study group. Now he believes finance and banking is not a difficult major to study. 


\section{d. Future expectations}

\section{Employment}

Sam chose finance and banking because he hoped that there would be more banks and job opportunities. Sam believed what he learned would help him to get a job.

\section{Work conditions}

Sam was influenced by projected future work conditions. He was not interested in working in agriculture. He likes the idea of working in an office and using computers. He likes bank uniforms. He said "You know one of the reasons I chose finance and baking is the nice staff uniform. I want to wear a bank uniform.”

\section{Potential income}

Another major reason for Sam to choose finance and banking is his expectation of a good salary. He expressed a desire to earn money and help support his family.

\section{Interdependency}

Sam's family supported his study. In return, he expects to get a job, earn money, and to support his family: "I have to study hard and get a job so that I can help my family's living conditions."

\section{e. Key influencers}

\section{Influence of family}

Sam's extended family had a major influence on his choice of major. Sam's uncle who works for a bank was actively involved in his decision making. Sam's parents did not get directly involved in the decision-making process, but they supported his choice and paid his school fees. His relatives and neighbours agreed that his choice was good as he said, "My family, relatives and people in my neighbourhood agreed it's a good major."

\section{Influence of peers}

Sam's decision was influenced by his friend, who was a second year finance and banking student. His friend provided him with information and persuaded him to choose this major. 


\section{Information sources}

Sam did not talk about other information sources relevant to his choice of major besides the information from his uncle and his friend as mentioned earlier.

\section{Future career plans}

Sam started looking for work in a bank during his first year at university but he failed to get a job due to his lack of experience. He has continued searching for work but so far he has not been successful. He still wishes to work at a bank and plans to run a business although he is not sure what kind of business at this stage. He said "I plan to get a good job and run my own business. I haven't thought about what business yet."

\section{Why not other majors?}

Similar to other participants, Sam's choice of major was related to the study skills needed for doing a major. He chose against doing law because his writing skills and ability to rote learn were not good. Sam's decision not to choose law was partly made by seeing his relative who has remained unemployed since completing his law degree.

A summary of how Sam chose finance and banking is shown in the following diagram.

\section{Figure 4.7. Factors that influenced Sam's choice of major}

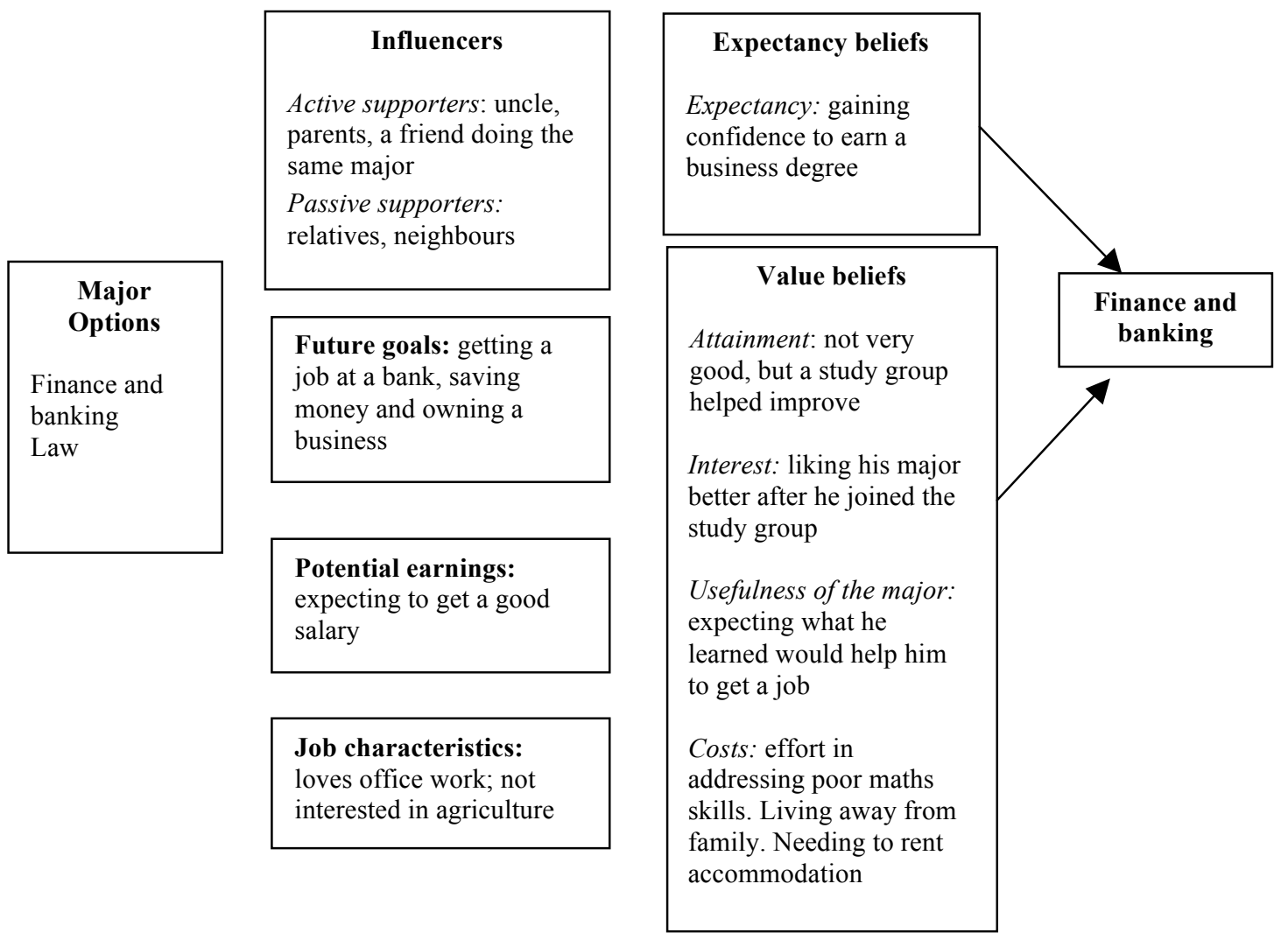




\section{Case eight: Sokha}

Sokha is 22 years old and from one of the largest rice production districts of Battambang. Her parents are farmers who cultivate rice. Sokha has a younger married sister. Sokha has the highest education level in her family. She is the only research participant who received a scholarship from a non-governmental organization (NGO). She lives away from her family in a house, which belongs to the NGO. She lives with other students who won the same type of scholarship. She has been interested in finance and banking since she was in grade 10. When she was young, she dreamed of working for a bank and wearing a beautiful uniform. Sokha grew up in a poor family, from a rural district. She found encouragement in her dream of working at a bank. As a high school student she would see bank staff working in nice environments, wearing beautiful uniforms and in air-conditioned buildings. This type of job has a good reputation in Cambodian society.

\section{Motivation to choose finance and banking}

\section{a. Expectancy}

Sokha believed in her own ability to achieve the degree. She was confident that she would finish the degree even though she had challenges. Sokha said "However, I am confident to earn the degree and I won't make my family hopeless."

\section{b. Attainment}

She is confident in her ability to study finance and banking. Sokha did not want to choose a major if she thought that she would not do it well in it. For example, she was interested in tourism, but she did not choose it because she knew that her English was poor.

\section{c. Interests in the major}

Sokha expressed strong interest in finance and banking and the related career. She does not anticipate changing her current major. Before she enrolled in finance and banking, she considered other choices such as tourism and English literature but she did not choose these because she did not have the essential skills and did not like the anticipated future work conditions. 


\section{d. Future expectations}

\section{Employment}

She expects to get a job at a bank and plans to pursue a postgraduate degree.

\section{Work conditions}

Sokha placed importance on future working conditions when she made her choice. She did not choose tourism because it required travelling a lot in the heat. She preferred office work wearing a nice uniform as she said, "I used to think about giving up my future goals but I really wish to get a job with a nice uniform.”

\section{e. Key influencers}

\section{Influence of family}

Sokha did not talk a lot about the involvement of her parents and grandparents. They agreed upon her choice. Her relatives agreed that she had made a good choice. She said:

My relatives, grandparents, and parents support me to study finance and banking. However, I made the decision on my own because I have liked it since I was at high school.

\section{Perseverance}

\section{Scholarship contract}

As a scholarship student, Sokha has a contract with the NGO donor. They pay her school fees and have offered training such as computer and English language skill training. In return Sokha is required to study hard and successfully complete her qualification. The contract is a cause for her perseverance.

\section{For her family}

Sokha chose her major in an attempt to do her best for her family. From what she said, family is very important to her. This sentiment encourages her to study hard and persevere with her current major. She said the following:

When I was at high school, I thought that it was difficult for me to study a bachelor degree because my family is poor and I live far from school and the 
university... So I keep working hard to reach my goal... I have never wanted to change majors.

\section{Information sources}

Sokha did not mention information sources such as teachers, friends, or so on. She showed her confidence in choosing a major and it was in accordance with her goals. The only agent who helped her with employment information was the scholarship donor who is implementing a project in Battambang. The organization is mentoring her through the part-time job they have provided her with. They have been helping her to develop necessary skills such as computer and English skills. This work experience will help her to get a job.

\section{Future career plans}

Sokha's current studies are preparing her for future work in a bank. She has been following her dream. A summary of how Sokha chose finance and banking is shown in the diagram below.

\section{Figure 4.8. Factors that influenced Sokha's choice of major}

\begin{tabular}{|l|}
\hline Major options \\
Finance and \\
banking \\
Tourism \\
\end{tabular}

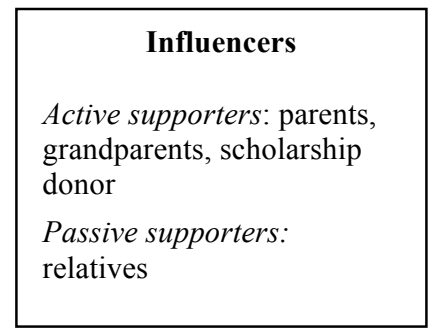

Future goals: getting a job at a bank and pursuing a postgraduate degree

\section{Job characteristics:}

wanting to work in an office and disliking travelling

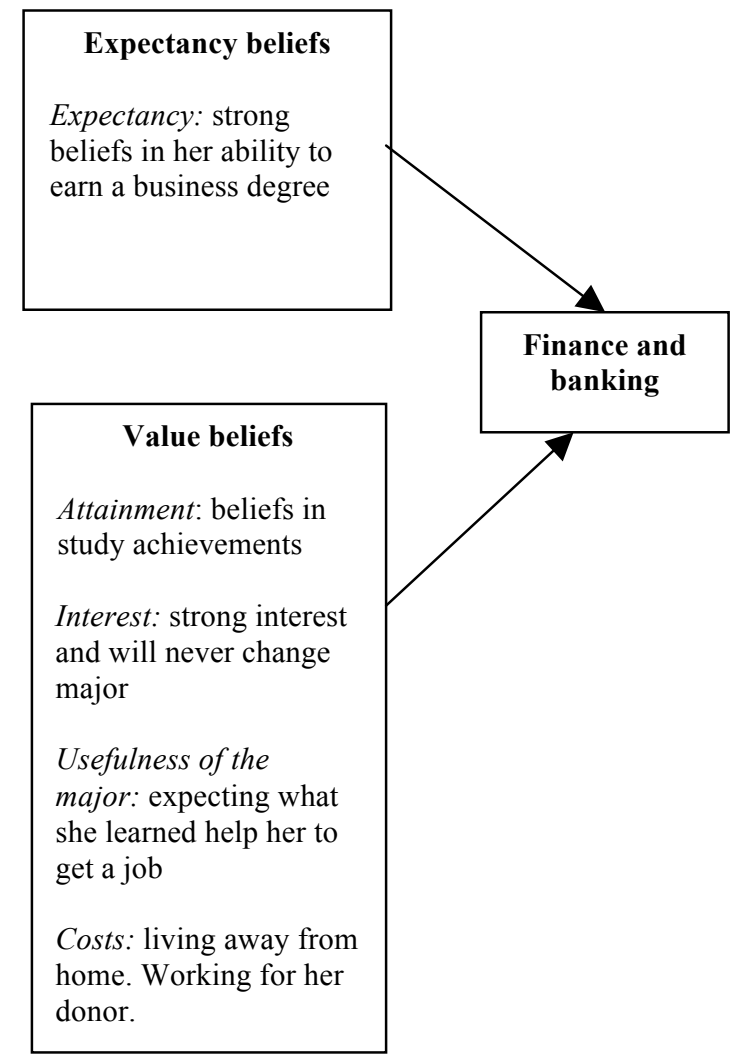




\section{Case nine: Phally}

Phally is 20 years old. She is from a district, which is about 40 kilometres from Battambang. Phally travels from home to university each day. Her father is a farmer and her mother a tailor. She has four siblings. One of her elder sisters is a teacher and another works for a company. Her elder brother is in his second year at university. Her youngest sister is in grade 7 . The elder siblings were key agents in her decision making.

\section{Motivation to choose finance and banking}

\section{a. Expectancy}

Phally expects to graduate with a degree in finance and banking and work for a bank in the future.

\section{b. Attainment}

Phally knew what she was and was not good at, for example she was not good at rote learning. Her self-belief in her learning skills was important in her choice of major. She struggled with lectures because she did not have good learning techniques. However, she relied on perseverance. She has strong determination to achieve her degree. She said:

After that I did not choose law because I'm not good at learning by heart... I have some problems, for example I don't understand some lectures, few lectures. I don't have a good technique to learn and I plan to ask my sisters because they know how to learn better. Another problem is budget, but I won't give up and I don't plan to change my major.

\section{c. Interests}

Phally believes she made the right decision and would not change her major. She would choose not to do a major that required learning a lot of content and theory. She said "I did not choose law because I don't like learning theories by heart." 


\section{d. Usefulness of the major}

She believed finance and banking would be very useful and it included other important subjects such as accounting. She stated that "My family agreed that this major is the best choice and it also covers accounting."

\section{e. Future expectations}

\section{Employment}

Phally made a comparison amongst her options in terms of the labour market. She expected that finance and banking would have more job opportunities than other majors including accounting and management. Like other participants, she expected to get a job in a bank.

\section{f. Key influencers}

\section{Family}

The experience of siblings influenced Phally's choice of major. Her well-educated elder sisters and elder brother gave her suggestions and information on the labour market. They encouraged her to choose finance and banking. Her parents who have a lower level of education were not actively involved in the decision-making process. However they agreed with her choice and supported her budget to do the degree.

\section{Information sources}

The main sources of information, on majors and the labour market, were her elder siblings. Phally trusted them.

\section{Future career plan}

Phally views working for a bank as a step for her to reach her next plan: owning a business. She said "in the future, if I have a job, I will save money to run my own business."

Phally is preparing for her future plans. She is improving her English and computer skills. She will volunteer or get an internship at a bank to get experience. Then, she will apply to work for a bank. 
A summary of how Phally chose finance and banking is shown in the diagram below.

Figure 4.9. Factors that influenced Phally's choice of major

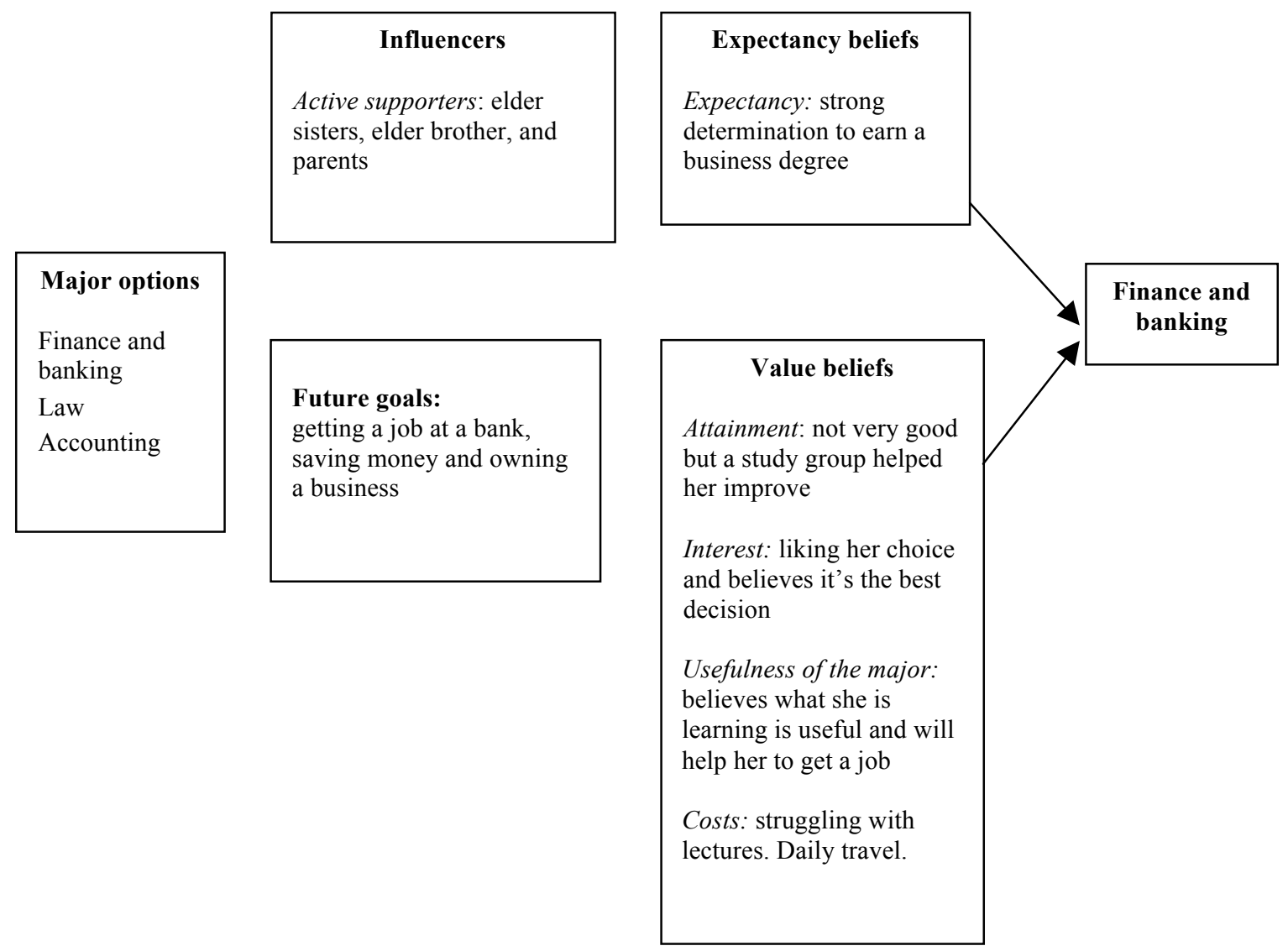

\section{Case ten: Chea}

Chea is 19 years old and lives in Battambang town. Her parents work for nongovernmental organizations. From the researcher's observation and parents' employment, her family's living standard is higher than other participants. Her parents worked rigorously with her to make a good choice. Her family's educational background was noticeable. Chea wanted to study jewellery design but this major is not available in Battambang Province she would have needed to do it in Phnom Penh, which would have been more expensive and she would have needed to live away from her family. Thus, she decided not to choose jewellery design. Even though she is not doing her ideal choice, she has not given up her ideal major and plans to do it once she can finance it herself. She has a clear plan for her future. Before choosing her major, Chea had a clear process. She collected information and suggestions from different 
sources: family, teachers, and friends. Some factors pushed her to choose finance and banking whereas others pulled her from that choice. The influencing factors are listed below.

\section{Motivation to choose finance and banking}

\section{a. Expectancy}

Chea was aware of the large number of students doing finance and banking and the future competition in the labour market, but she was confident that she would be able to complete her degree and get a good job. Chea said "I think it's individual capacity. I believe I can get a job if I really have good knowledge and strong skills. Then, I determined that I need to graduate in this major as it is my choice."

\section{b. Attainment}

Chea believes that if she studies hard, she will be able to achieve her degree even though there are many students in the class. She described herself as a persevering student. She is confident in her ability to be a good learner.

\section{c. Interests in the major}

Chea's interest in financial tasks motivated her to choose finance and banking. She loves finance and banking and she does not plan to change her major as she said, "I love finance and banking. I don't want to change my major and I don't want to waste the year I have learnt."

\section{d. Future expectations}

\section{Employment}

As mentioned earlier, Chea has a clear future plan and chose finance and banking because she believed that the labour market was growing and she trusts her ability to get a job,as she said, "In fact what I chose was due to future job opportunities."

\section{e. Usefulness of the major}

Chea believed that learning finance and banking is useful for her to get a job and run her own business. She found that finance and banking had the most advantages when compared with other options. 


\section{f. Unavailability of the actual interest major}

Her choice of major was a step toward her eventual plan. Chea preferred another major, which was not offered by any university in Battambang Province. She chose finance and banking to get a job in order to save enough money to support her future study of her favourite subject.

\section{g. Costs and location}

Chea did not choose what she really liked, designing jewellery, because of factors such as higher expenses and being away from her family. There would be extra expenses if she moved to study in Phnom Penh. She did not want her family to spend much money. Chea said the following:

What I actually like is jewellery design. I have liked it since I was young. I didn't do jewellery design because there is no course available in Battambang. I need to do it in Phnom Penh, which is far from home and the expense is higher than studying in Battambang. Thus, I put aside my interest. I need to get a job and save up for studying my favourite major later on.

\section{h. Key influencers}

\section{Influence of family}

Chea's family, including parents and grandparents, was actively involved in her decision making. They encouraged her to make a careful decision. Her parents did not point out the choices but encouraged her to assess potential options. Her parents supported her with selection techniques, advice, and finance.

It is interesting to note that in Chea's case her grandparents were actively involved in the process. They were knowledgeable about the current and future labour market. Her grandparents did not want her to choose finance and banking. They drew her attention to the high number of students in this subject area, and the number of graduates who were unemployed for a significant period. They recommended that she study accounting and economics. Despite the opposition from her grandparents towards a major in finance and banking, Chea was determined in her decision. She made her decision very carefully. However, their opposition helped Chea to learn more about the labour market and become clearer about her choice. She said: 
Almost everyone agreed that this major is the best, except my grandparents. They said many students are doing this major and many of them spent a long time hunting for work. They recommended accounting and economics.

\section{Influence of high school teachers}

Like most participants, Chea searched for suggestions from her school teachers before making a decision. She talked to her morality teacher. Her teacher suggested that finance and banking was a good major and that her daughter was doing the same major. Although her teacher was not actively involved in the decision-making process, her advice motivated Chea to gain more confidence in the choice she had made.

\section{Peer influence}

Peer influence in her case was also significant. She wanted to change her major following her friends' suggestion. Those friends were studying different majors. She stated that:

Once my friends told me that the job market of finance and banking was small and competitive, I wanted to choose another major. However, I thought it depends on individual abilities.

\section{Information sources}

The main sources of information related to the major and the labour market were her parents, and schoolteachers. Other sources of information were friends and bank staff.

\section{Future career plans}

Chea described a clear set of future plans. She plans to get a job in finance and banking after she graduates. Then, she plans to enrol in jewellery design and run her own business. Her current business plan is an Internet shop and she has already started to manage the shop. 
A summary of how Chea chose finance and banking is shown in the diagram below.

\section{Figure 4.10. Factors that influenced Chea's choice of major}

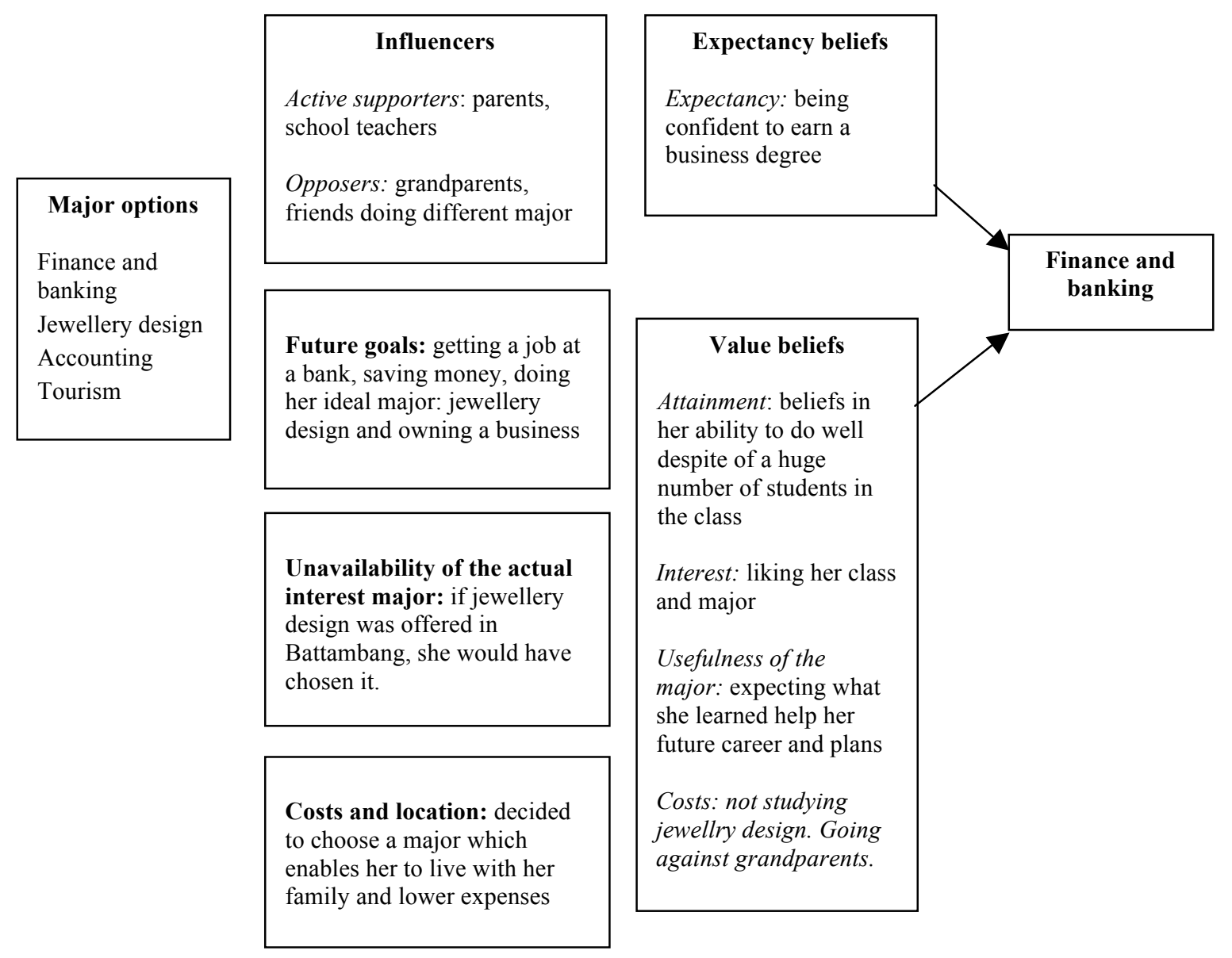




\section{Chapter Five: Findings from cross-case analysis}

In the previous chapter, the findings of each case were described. In the current chapter, findings of the cross-case analysis of the 10 cases will be elaborated and discussed. The cross-case analysis was conducted in phases. Attention will be placed on similarities and differences in the cases to understand students' choice of a major. The findings will be presented accordingly. First, the answers to the first research question, which focused on how student's beliefs contribute to their choice of major, were analysed. These beliefs were in accordance with the expectancy-value theory. Next, the key influencers on students' choice of major were identified from across the 10 cases. Cultural influences were discussed in this section, as the impact of key influencers was relevant to Cambodian culture. Thirdly, sources of information related to majors and the labour market were discussed from the findings of each case. Lastly, a pattern of students' future plans was drawn.

Some key similarities among the 10 cases include the reasons they chose finance and banking. This was mainly for the expected job opportunities. The expected job was seen as a stepping-stone to achieve their long-term goals, which was most commonly owning a business. Their decisions were dynamic changes. Three different patterns were drawn from their changing decisions. The first group of participants, including Chamnab and Navy, changed majors at least once. It is common for young people to change their minds. Participants, such as Sophy and Sokha, made a straightforward decision in their choice of ideal major, while for others the decision-making process was more complicated. Their decisions were influenced by family, friends, and teachers as well as some other factors. More detailed descriptions of influencing factors on students' decisions will be discussed in the following section.

\section{Motivation to choose a major}

\section{Competence beliefs: Expectancy}

Each research participant considered their belief in their capability to complete their study, when choosing a major. Almost all participants expressed confidence in their ability to complete the degree. Sam was not confident at first and was about to change 
majors; however, once he gained confidence in studying, his determination to earn the degree increased.

When participants considered their options before making a decision, their self-belief and confidence to succeed was important. They did not choose a major that required essential skills or knowledge that they did not have nor like. After the first institute he attended went bankrupt, Mara decided not to continue doing management. He thought management was difficult whereas Mony, Boeb, Navy, Sam, and Phally chose not to study law because they believed that law involved learning theories and rote learning.

\section{Value beliefs}

\section{a. Utility values}

\section{Good employment}

The perceived usefulness of a degree played an important role in participants' choice of major. All of the research participants expected that what they were learning would enable them to get a good job in the future. Most expected future growth in the number of banks, which would create more job opportunities. All participants planned to work for a bank or a micro-finance institution.

All of the participants listed 'job opportunities' as a priority in choosing one major over other options. However, it should be noted that they did not have robust information about the labour market. Typically they discussed their options with key influencers. This will be discussed later in the chapter. There were discrepancies in the participants' perceptions of the future job market. For example, Phally expected more job opportunities if she majored in finance and banking as compared to either accounting or management. On the other hand, Navy had decided to change her major in the following year because her family believed that accounting would have better job opportunities than finance and banking.

The participants believed that the skills they were learning were highly relevant to what they planned to do in the future: getting a job or running a business. These students chose finance and banking because they thought that this major would be useful in their future career and goals. 
A few participants mentioned career development as important to their choice of major. For example, Mony chose his current major because he expected to be employed in the government sector. He expected promotion, which would enable him to work towards his second goal, which was to be involved in politics. Another participant, Boeb, expected that his future job would provide opportunity for him to be promoted to bank manager, which had been his ideal job since he was in grade 9 .

\section{Potential earnings}

The expectation of a good income from their future career was influential in the participants' decisions. While most were not explicit about what they expected to earn, most expected a high level of income. Five participants talked about getting a job at a bank and saving up money to start a business. Three participants were willing to save up for further education. It should be noted that Navy, who plans to change her major, spoke about the exact amount of money she wanted to get from her major-related career, accountant. Out of the 10 participants, she expressed the highest interest in perceived career and earnings, which were the main reasons for her to change her major.

In short, the findings show that the utility value was one of the main factors influencing students' choice of a major. Students expected their chosen major would contribute to their future career and salary. They intended to get a good job with a high salary so that they could save up for their long-term goal either owning a business or pursuing a higher degree.

\section{b. Interest/enjoyment}

Most participants enjoyed their studies. They loved their coursework and expected to persevere with learning in order to graduate and get a job in their chosen major.

Some participants mentioned some courses they did not like, for example philosophy. However, they seemed to enjoy most classes. Mony emphasized that he liked his study because it was interesting.

Navy, who has decided to move to an accounting major, did not mention that she disliked her finance and banking class. Despite her moderate enjoyment of finance and banking, she had decided to change her major to accounting because of better employment prospects. 
Overall, participants chose finance and banking because they expected that they would like the coursework involved. Most participants expressed their confidence in their maths skills and they enjoyed their classes. Their beliefs in their ability will be discussed in the following section.

\section{Work conditions}

Half of the participants connected favourable work conditions (e.g., office work, nice uniforms) with their choice of major. Chamnab, Sophy, Boeb, Sam, and Sokha chose finance and banking in order to have get a job with conditions such as working in an air-conditioned office wearing nice uniforms, and using computers rather than working in the fields. Cambodians view office jobs as much better than agricultural work. This perspective will be elaborated in the discussion chapter. It is interesting to note that both male and female students mentioned about the importance of future career conditions, including "beautiful uniforms."

\section{c. Attainment value}

The participants chose finance and banking because they believed in their own ability to do well. Participants chose this major because they believed that a career in finance and banking would match their aptitudes. For instance, participants thought that finance and banking required maths skills. Mony, Mara, Navy, Sokha, and Chea chose finance and banking because they were confident with their maths skills. Chea liked finance-related tasks. Before he joined a study group, Sam wanted to change his major because his attainment value was low, meaning that he did not believe he could do well in finance and banking. After joining the study group his confidence improved and he stopped thinking about changing his major.

Importantly, most participants viewed a finance and banking degree as the base for an interesting career. As reported earlier, five participants planned to run a business in the future with savings from their bank jobs. Three participants intended to save for further education. Participants chose finance and banking because they believed it would help them to achieve their long-term goals, which went beyond that of working at a bank.

Overall, participants chose finance and banking because they knew their own abilities and it was consistent with their long-term career aspirations. The significant role by families in the choice will be addressed later in this chapter. Almost all participants 
considered finance and banking as a pathway to other future career plans, which is mostly to own a business.

\section{d. Cost values}

Cost refers to the total price of time, effort and psychology in completing a task (Eccles, 2009; Eccles \& Wigfield, 1995). In the current study, costs refer to both the sacrifices made to pursue a major in finance and banking, and to proceed to a career in that field, and to the resources required (money, time and effort).

\section{Cost and locations}

The expense of doing a particular major had a crucial impact on the participants' choice of major. Expenses can be considerably higher when students move to study in another city, because they need to spend money on rent and other relevant costs. Whereas, living with their families, these costs can be significantly lower.

Expenses include fees and additional costs to earn a degree. Some majors such as medicine are well known for their high cost. Some participants experienced barriers to choosing an alternative major and decided not to pursue their ideal major. Navy stopped studying law after one month because her family could not afford the expense and she returned to study in Battambang.

More than half of the participants did not pursue their choice of major either because of the financial costs or because of decision made by their families. Two students were affected by the instability of private education providers. Three of the four students not living at home found this difficult, and this was a sacrifice made to pursue the major. Several students referred to the efforts of their friends to persuade them to join them in other majors. For these students it appeared that effort was needed to resist persuasion, as this involved not pleasing their friends. The Cambodian students appeared to place emphasis on studying with friends. Other cost factors experienced by individuals or small number of students included needing to put time into extra study or struggling with difficult subjects.

\section{Perseverance}

Most participants, except Navy, revealed their perseverance in doing finance and banking. Most of them claimed that because of their future goals, they do not expect to 
give up their study (e.g., Mony, Phally, Sophy, Mara, and Sokha). Some mentioned that they will study hard and will not disappoint their families (e.g. Sam, Sokha, and Chamnab). Even though their reasons for persevering to learn finance and banking are various, most of them plan to graduate with a degree in finance and banking.

\section{Cultural influences on choice of major}

\section{Family ties and inter-dependency}

The study found that family ties are very important among research participants. Both male and female participants mentioned their family's role in their decisions. Almost all participants received financial support from their family. Some participants said they wanted to eventually support their family. Others mentioned that they expected their major would help them to get a job and to support their families. There was no sense that parents expected the students to compensate them for what they had invested or take care of them when in old age. However, from what participants said, participants had been planning to help support their family once they get a job. Interdependency is revealed among the relationship between participants and their respective families.

\section{Mobility}

Most participants, both male and female, chose to live with their family. They avoided choosing a major that required them to live far away from their family. Chamnab, for example, chose not to do a tourism major because he did not want to live away from his family. He said it was not because his parents were old, but because he has never lived apart from his family. A female student, Sophy, raised her family's concerns about security for girls who live on their own. Unlike other participants, only one participant, Mony, likes to travel and live far from his family. He demonstrated the most independence and had clear future plans. In general, unlike youth in Western countries, Cambodian youth like to live with their parents for a longer period of time. Some of them move out after they get married, but many of them stay together as extended families. Because they have never experienced living on their own, they are not confident to move out. 


\section{Key influencers}

The research participants' decisions were not made individually, but involved other people who were influential such as senior family members, high school teachers, and relatives with bank-related experience. Participants searched for advice from a variety of people.

\section{a. Influence of family}

The study found that the choice of major was more a family choice than an individual's. The family relationship was influential in participants' decisions. The current study identified key family members who influenced participants' choice of major including elder siblings, mother and/or father, senior relatives, and grandparents.

\section{Siblings}

Almost all participants mentioned how their siblings were actively involved in the decisions. Elder siblings who were tertiary educated or worked in relevant areas were actively involved in the decision-making process. They provided participants with advice to assist in their decision making. Siblings who were responsible for the family's income were influential in the decision-making process. However, they were more involved with cost-related decisions rather than a choice of major. For example, Boeb's elder sister, who is the family's breadwinner, made the decision for Boeb as to whether he would study in Phnom Penh or Battambang. However, she did not advise on which choice of major was the best. More participants mentioned their elder sisters than their elder brothers (e.g., Chamnab and Phally). Elder siblings, especially elder sisters, played a very important role in the decision-making process of the participants.

\section{Parental influence}

Parents play an important role in Cambodian families. In the current study, most parents finance participants' university fees and living expenses. Parents with a low level of education, specifically those who are farmers, were not involved in their child's decision-making process regarding a major. One reason was that they lacked knowledge of the labour market. Parents who are well-educated were active in the decision-making process. In a family where parents were farmers and not welleducated, siblings or relatives who are well-educated were more influential. Elder siblings were more involved than parents. Parents agreed with any choice other than 
majors that would lead to a career in farming. The reasons for parents to discourage their children from choosing farming-related majors will be covered in the discussion chapter.

\section{Relatives: Uncle/aunt/brother-in law}

The majority of research participants mentioned seeking advice from relatives (e.g. uncle or aunt) who had studied or worked in banking or finance. The influence of these relatives is significant. For instance, Navy's uncle advised her to change from finance and banking into accounting. Navy followed his advice.

\section{Grandparents}

Among the 10 participants, only Chea reported the involvement of her grandparents in the choice of major. From what she told the researcher, her grandparents are welleducated and knew the strengths, weaknesses, and the labour market associated with various majors.

\section{b. Influence of high school teachers}

Because there were no career counsellors in Cambodian high schools, students sought career guidance from their school teachers. Participants sought assurance from these teachers before they chose or changed academic majors.

\section{c. Peer influences}

Both male and female students asked for their friends' opinions before they decided to choose a major. Even though participants' final decisions were made with family members, friends' influence was considerable in this study. A few participants were strongly influenced by their peers. For instance, Chamnab chose his first major based on what his girlfriend was studying.

Friends who were doing the same degree were reported to be a pull factor to enrol in finance and banking. Friends provided detailed information on courses and on the labour market. They encouraged participants to choose finance and banking (e.g. Sam and Boeb).

Friends wanted the participants to choose the same majors as they had chosen, as indicated by Mara. On the other hand, Sophy described her friend who was doing a 
different major, had encouraged Sophy's choice and also wished to change to study finance and banking with her.

In short, both male and female students received pull influences from their friends who were doing finance and banking and push influences from their friends who were doing other majors. Despite friends being identified as a source of information related to the major they were not actively involved in the decision-making process.

\section{Neighbours}

A number of participants mentioned neighbours in their decision-making process. Neighbours' influence was not direct. They confirmed the choice and provided assurance that choice was a good one. Participants referred to their neighbours as people who made them more confident that their choice was a good one.

\section{Information sources}

Research participants reported the main sources of information related to the choice of major and its associated labour market included siblings who had a higher level of education, school teachers, friends who were doing finance and banking or related majors, relatives who worked in the finance and banking sector, well-educated parents, and bank staff. Only Chamnab mentioned media including radio and newspaper as main sources of information.

\section{Future goals and career plans}

Most of the participants mentioned that finance and banking was the major, which could assist them to reach their goals. All participants spoke about working at a bank after graduation. Some of them have dreamed of working at a bank before they finished high school. Choosing finance and banking may help them achieve one of their goals.

Boeb reported that his goal of working for a bank began when he was in grade 9. His goal is to work for a bank and become a bank manager. This means his goal is rooted in his major and his future career is very relevant to his current major. 


\section{Career plans}

The future career plans of the 10 participants tended to be similar. Almost all of them plan to work for a bank or micro-finance institute. A few of them planned to apply to work at a bank from the time of the interview, while the majority planned to do it after graduation.

\section{Desire to run a business}

Working in a bank was reported to be the first step in their future plan. Most of the participants described long-term future plans. Many planned to run a business. They aimed to work for a bank to save enough capital before starting a business. However, most of them were not sure what kind of business they wished to own yet. Chea was the only one who has started to run an Internet shop.

A few of them talked about pursuing higher education. Only one of the 10 participants talked about his personal family plans and involvement in politics. He believed that what he has been learning will contribute to the development of the country while other participants were more concerned about employment, income and future business prospects.

Chea raised an interesting point. Her real interest was in another major, which she could not do at the time of the fieldwork. Her current choice of major was a staircase to reach the next level of goals: to do her real interest major and to run a business.

In short, participants chose finance and banking as a stepping-stone in order to achieve their bigger goals and long-term plans. Almost all participants have planned their future career in a common pattern. The steps go from a short-term goal to bigger ones as displayed in Figure 5.1.

Figure 5.1. A common pattern of participants' future career plans

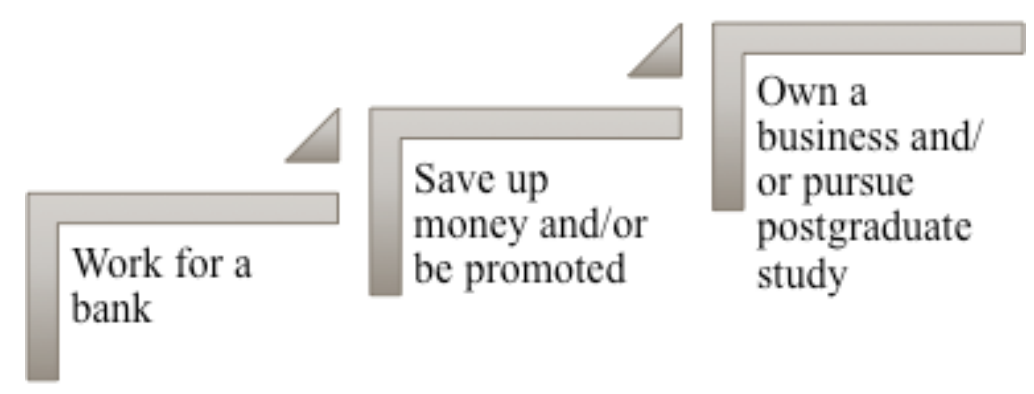




\section{Why not other majors?}

The most important reason for participants to consider when they made a decision to choose a major was the impact on their future careers. Participants mentioned that they chose finance and banking, but not other majors, because they believed that finance and banking offered better job opportunities. Sam, Mara, and Chamnab choose not to do another major because they believed that it would be hard for them to get employment in the other field.

Interest in the major, attainment values and expectancy were significant consideration for students when they decided against taking a particular major. If participants believed that they did not have the essential skills for a specific major, they would not choose this major. Participants compared skills such as numeracy to theory learning. Many of the students recalled disliking the rote learning and theoretical learning required for tests and exams in subjects such as law. Those who liked maths and sciences tended to choose finance and banking or accounting but not law.

Future working conditions were another criteria students used for deciding against taking a particular major. Many students dreamed of wearing nice uniforms and working in air-conditioned rooms. Office work has a higher value compared to agricultural work in Cambodia where the weather is almost always hot. They avoided choosing a major, which led them to work out side as they believed that this would be hard work. Chamnab chose against tourism because he did not like travelling and working in the sun.

The location and the broader costs of doing a major were significant factors in the decision-making process. Five participants decided not to take a major which required them to move away from their families and because that major would have cost more than doing a degree in Battambang province. Navy spent a month learning law in Phnom Penh. Her family asked her to come back to do a degree in Battambang because it was much cheaper.

\section{Summary of the findings}

This chapter set out the similarities and differences amongst the 10 cases. Students' choice of major was influenced by the value beliefs students had about the major and 
their perceived career. The value beliefs included utility, interest, attainment and cost values. Their expectancy value within the major was also salient. Major findings are summarized below.

First, utility value is one of the most important factors in these students' choice of a major. Almost all students chose finance and banking because they believed that it would lead to a good job following graduation. Most of them expected a growth in the number of banks. Many expected to receive a good salary working at a bank.

Second, a student's interest in the major and perceived work conditions and social value were pivotal. Cambodia is an agricultural economy with a high number of subsistence farmers(Yu \& Fan, 2011). Cambodians value office jobs more than fieldwork. Jobs that require working in the field (e.g., engineers, agricultural officers) tend to be considered harder than office-based jobs and typically earn a lower income.

Third, a student's belief in their own ability influenced the decision they made to study and persevere with a major. Most participants were confident they would do well in the major because they had good math skills. Many did not choose a different major, for example law, because they believed studying law involved learning theories and rote learning. They lacked confidence in their ability to do well in law studies.

More importantly, the choice of a major tended not to be an individual choice but a family one. The study found a strong influence of extended family and an acknowledgement of interdependency in the choice of a major. The decision-making process often involved siblings, parents, uncles, aunts, grandparents, and other relatives. Some participants talked about their expectations of employment and being able to support their families in the future. Some of them said they would not make their parents "hopeless." This illustrates that their choice was important for their families as well as themselves and an important dimension was the expectation that they would support their families in the future.

Most of the students avoided choosing a major that would require them to move away from their families. Because majors such as jewellery design are not offered in Battambang, students wanting to study such majors need to study in Phnom Penh. The students decided against such majors because they had never lived away from their parents and they did not want to do so. 
Key influencers on students' choice of a major were found to be siblings, parents, extended family members such as uncles and aunts, friends, and high school teachers. People who had a high level of education and were working in fields related to finance and banking had an important influence. The most influential people were siblings and extended family members. They were actively involved in the selection of a major out of various options. Typically, parents did not advise on what was the preferred major, but they were sometimes financial supporters. Students sought additional advice from their friends and high school teachers. Many students asked for information about the major from their friends who were doing finance and banking before they made their final decision. High school teachers sometimes played an important role as career advisors.

There did not appear to be reliable or impartial sources of information on the labour market that students could draw on during the decision-making process. Participants were reliant on what their siblings, relatives, friends, and teachers told them.

It is noteworthy that most students saw finance and banking as a stepping-stone. A common long-term goal amongst the students was to save money in order to start a business. Some plan to pursue postgraduate study following graduation. Many sought part-time work. Some volunteered in organizations because they wanted to gain work experience that would enable them to get a job and start a business in the future.

To sum up, the choice of major for these Cambodian university students has been shaped by many factors, including expectancy and value beliefs. Cultural influence was important. Family members, friends, and high school teachers were key influencers in the students' choice of major. 


\section{Chapter Six: Discussion and conclusion}

This chapter provides a summary and discussion on the research findings. This chapter will highlight the findings of the research question, "how and why do students choose to major in business?" The discussion will use the expectancy-value theory to focus on participants' motivations to choose a business major. The influence of each construct of the theory in the research findings will be discussed. Then, discussions related to Cambodian higher education and Cambodian culture will be included to provide understanding about the current practice of Cambodian higher education institutes (HEIs), issues relevant to students' choice of major in Cambodia, and awareness of current issues. This chapter highlights the significance of the research findings in the area of choice of career and/or major and Cambodian higher education. Some recommendations will be provided and a conclusion will be drawn at the end of this chapter.

\section{Reasons for choosing a business major}

The results of this study show that utility value was the most salient factor for these students' decision making. All participants expressed their family and their own concerns about future employment and the labour market, and how the major would contribute to their future goals, for example owning a business or becoming a bank manager and supporting their families. In contrast, Lent, Brown and Hackett (1994), Super (1980), and Holland (1997) identified interest as the most important factor in career decision-making. Conversely Matusovich et al. (2010) highlighted the attainment value over the interest and other values in a career choice process. The current study found that when comparing possible majors the participants and their families considered that expected job opportunities were a priority in their decisionmaking process. This is similar to other studies (D. Kim et al., 2002; Malgwi et al., 2005). Most participants expected to see growth in the banking and finance sector and associated employment. They expected to work at a bank and earn a good salary. Projected earnings are major reason for these students choosing to major in business and this echoes findings in some prior studies (Cebula \& Lopes, 1982; Dudley et al., 1995; Giladi et al., 2001; D. Kim et al., 2002; Malgwi et al., 2005; St. John, 2000; Swenson et al., 1993). 
The current research highlighted interest values as significant. It should be noted that the participants' interest in their future career was found to be more important than their interest in the major. Most participants chose finance and banking because they were interested in becoming a bank employee. Most described their preference for maths, numbers, or finance-related tasks. They choose not to do a major, which required them to learn materials and skills they did not like, or believed they would not be good at. The interest-related to subject/career was found to be the most important factor in some studies (Lent et al., 1994; Malgwi et al., 2005; Super, 1980)

The current study highlights a common pattern in participants' utility values. Most participants described their chosen major as useful for getting a job with a good salary. Then they intend to save sufficient capital to start a business. A common long-term goal is to own a business.

\section{Mobility and inter-dependency}

I was born and have lived in Cambodia most of my life. I am aware that the majority of Cambodian young people live with their parents even though they are over 18 years old. I still lived with my parents after getting married. This culture may create interdependency, with regard to all aspects of life and decision making. The majority of the research participants indicated that a major, which required them to travel or live apart from their families, stopped them from choosing such a major.

Only one student expressed a desire to live away from his family. He was the only one who expressed such independence of this nature with the rest preferring to stay with their families. Prior research suggests two views of the effects of location (Keller \& McKeow, 1984). First, some students wanted to go to an institution, which was close to their home so that they could be with their families and involve support networks whereas in contrast some students preferred the opportunities to move away from their home.

\section{An individual's or a family's choice?}

The participants were aged between 18 and 24 when the interviews were conducted. This meant they had made significant life decision when they were around 17 years 
old. According to Cambodian culture, they were too young to make such decisions alone. Their choice of major was more a family choice than an individual choice. The decision making involved extended families from grandparents, parents, siblings and other relatives. It was a family choice because it was considered one of life's major decisions, as they would have to invest effort, time, and money. They had to make sure that the decision was right from the beginning. In Cambodia, children are expected to take care of their parents when they are elderly. Whatever their decision was, it needed to be for both their family and themselves. There have been similar findings from prior studies with both Asian students who were born and then lived in their country of origin (Hughes, 2011; Lee \& Rojewski, 2012) and within Asian students who lived in a Western country (Mau, 2000; Song \& Glick, 2004).

The most influential people were found to be extended family members. Siblings and relatives, who had a high level of education and were working in relevant areas, played an important role in the decision making of a family with one or both parents were farmers. Siblings who were financially supporting the participants played a significant role in deciding which major. Teachers and friends were not significantly involved in the decision-making but were consulted. Participants sought their advice or assurance that their decision was right.

\section{Influences of parental occupations}

Parental occupations were found to have an impact on students' choice of major in this study. The majority of the participants' parents were farmers with a low level of education. They recommended that their children not choose an agriculturally-related major. One of the main reasons is their belief that farming is hard work and has low social status. They have little understanding about the varieties of job opportunities in the area of agriculture, for example agricultural scientists, marketing, and consultants. What they understand about agriculture is farming. Traditional farming in Cambodia is labour-intensive. Productivity is dependent on the weather due to insufficient irrigation systems. Therefore, farming is considered to be hard work and with little profit. Farmers send their children to school in the hope that they will not have to work on farms when they graduate. 


\section{Influence of parental education}

None of the participants' parents were tertiary educated. However, parents who had a higher level of education were more active and influential in the decision-making process. Mothers were more influential than fathers among both female and male students. In Cambodia, mothers play a more important role in taking care of their children, whereas fathers usually spend more time earning to support the family. In Cambodia, the relationship between mothers and children tends to be stronger than the relationship with fathers. In contrast, the literature suggests that fathers' influence is more significant in Western culture (Hoffman, Goldsmith, \& Hofacker, 1992). Interestingly, the current study did not find a difference between the influence of parents on male and female students, which differs from US studies which identified a larger effect of fathers who have a professional or executive job on female students, while mothers' influences were more significant on male students (Leppel et al., 2001).

\section{Information sources}

Family and friends were the major source of information informing the decisionmaking process. Only one participant mentioned public media including radio and newspaper as an information source about the labour market. It appears that mass information such as newspapers, radio and television either were not providing accessible information on the labour market and on careers or were not effective for these students and their families. This finding is similar to those of Maxwell et al. (2000), HRINC (2010) and the World Bank (2012) that parents and friends are an important source of information on study and careers. It is noteworthy that HRINC and the World Bank did not identify siblings as a source of information and or as key influencers. The current study found that siblings and/or other relatives, who had been to universities or were working in an area, related to finance and banking, were the most important sources of information. High school teachers were consulted as advisors in the student decision-making process rather than as providers of information on majors and the labour market.

It is noteworthy that Cambodian high schools do not have career guidance or counselors who can provide useful information on the labour market and help guide 
and support them to their interests and dreams(Cambodian Federation of Employers and Business Associations, 2008). In addition, it is likely that there is no reliable source of information on labour market demands. Links with the employment market and the private sector in building curricula are the responsibility of the university (Innes-Brown, 2006). Without a labour market information system, which can inform universities proactively as to future skills needed, development and implementation are often reactive in addressing the needs of the market as they arise. As indicated in the literature review, the most effective information in decision making works within social networks, which require interpersonal communication (Christie et al., 2004). Interpersonal information networks include parents, families, friends, teachers, career counselors, and tertiary staff (Brooks, 2004). These key people need to work together to inform students about their study and/or career options.

\section{Barriers to a dream major}

The expense involved was a key obstacle to students choosing their ideal major (e.g., medicine, or jewellery design). Some participants did not choose a major because it required them to spend more on living and other related costs. Provincial higher education institutes (HEIs) do not yet provide a wide range of alternative majors for students to fulfill their dreams and interest. The availability of major options may be less in smaller and/or distant provinces and cities, for example Pailin, Ratanakkiri, Mondulkiri, Steung Treng, and Kratie.

There was some evidence of a growing awareness of the differences in the quality of education offered by education providers. Participants believed that some universities in Phnom Penh provided a better quality education for some majors, for example information technology and law.

Many Cambodian HEIs are likely to offer programmes that are less costly to run (Innes-Brown, 2006). The less costly programmes are seen to be business, law and management (Ford, 2006; Odin \& Manicas, 2004). Consequently, they do not contribute to the creation of knowledge and the development of the much needed knowledge and skills in agriculture, science, engineering and technology, areas where there is a shortage of skilled graduates. Nor have they developed comprehensive programmes in the arts and humanities. It is important to note that 
only one out of the ten participants mentioned how his study will contribute to the future development of the country. The nine others prioritized employment, expected income, and future business plans. The aims of higher education are more than employment; they should also be about social values and development (MoEYS, 2004).

Not many HEIs, especially those in provinces, offer STEM, agriculture, and law, which are the main majors the government accords as important for social development(HRINC, 2010). If HEIs provided a wide range of majors and the quality was assured, students would have been able to choose what they really liked and then be able to serve the social needs and development of Cambodia.

\section{Cambodian institutional accreditation}

Two participants, spent time studying for a major at a private university and institute. The private university where one had been studying dropped the major in response to low enrolments. Another could not pursue his management major because the private institute he was studying at went bankrupt during his third year of study. There was a waste of time, finances, and effort for these students. Their experiences illustrate why there is a growing demand for improvements in institutional accreditation and quality assurance within Cambodian HEIs (Chet, 2006; Ford, 2006; Sloper, 1999). Academic scholars, commentators, and the public have been calling for greater oversight and regulation from the Accreditation Committee of Cambodia (ACC) especially in licensing education providers (Chet, 2006; Ford, 2006; MoEYS, 2009). In the congress report of 2006, Ministry of Education, Youth, and Sport raised an issue that some HEIs using the name University obviously have neither the capacity nor the possibility to be a proper HEI.

Many universities and HEIs were founded prior to the establishment of the ACC. In the current competitive environment, some HEIs market attractive academic programmes, which they do not provide in reality. Students enrol believing the marketing, and then their studies are terminated due to factors outside of their control namely the inability of the institution to provide the programme. It is the responsibility of ACC to assure that HEIs have met minimum standards of accreditation(Chet, 2006). While accreditation policies and standards require that be robust assessment and 
clearly articulated policies it appears that there is a gap between requirements and what happens in practice.

\section{Contribution of the research}

The choice of a major is a topical issue in Cambodia, with there being an oversupply of graduates from business related majors and a shortage of graduates to work in agriculture, science, technology and engineering (HRINC, 2010; World Bank, 2012). There is an established body of research looking at the choice of major in a north American context but little research has been conducted to understand how and why Cambodian students choose a major. The current study used a qualitative case study approach with in-depth student interviews to understand their motivation to choose a major. The study made use of an existing theory, Eccles's expectancy-value theory in order to develop better understanding of the extent to which the theory is relevant, and can be extended and adapted in an Asian context.

\section{Research recommendations}

This study provides a number of recommendations to people and agencies working in the development of Cambodian higher education, and those responsible for advising students on choices of majors and careers.

First, it is important for UBB and other similar institutions to continue focusing on teaching and learning quality. This study recommends a clear policy in monitoring and managing quality provision by both public and private universities and institutes. The quality of teaching and course provision need to be improved. Students invest their money, time and effort in their future. Low-quality education will bring about unqualified graduates in the future.

Furthermore, UBB and other similar institutions need to value a curriculum that serves both economic and social needs. A stronger curriculum of a better quality will increase qualified human resources as needed for socio-economic development.

The current study found that students did not have robust sources of information on the labour market. Choice of major is considered to be an important life decision. However, in the current research participants' decisions were made with unclear 
information and heavily reliant on the knowledge of families and friends rather than information on the labour market. It is recommended that the capacity and partnership of the National Employment Agency (NEA) be strengthened. There is a need for agents to provide guidance and counseling to students from an early stage, namely high school, to avoid rushed decisions with insufficient information. In addition, there would be merit in the universities employing specialized career counselors to provide further guidance as this study found that some students were not very clear about the labour market.

Next, there should be strong cooperation between these three agents. Transition from high school to tertiary education is a complex stage in a student's life. Thus, universities could work with the high schools to provide support and guidance to students in making their future plan early. They could cooperate in providing information on the current and expected labour market for students to prepare themselves for a well-considered decision after they finish high school. The universities should also work with high schools in strengthen networks with students' parents and extended family. Parents, siblings and grandparents have been found to be influential in the choice of major. Therefore, their role needs to be acknowledged, and they need to be encouraged to work with schools and universities to support their children for a good choice of major and/or career because schools may have significantly less knowledge about the labour market than universities.

Participants sought advice from their high school teachers. They thought that teachers would be knowledgeable and reliable counselors in such matters. Teachers act as career advisors for students. Therefore, more information on the labour market should be provided to teachers so that they can provide the best guidance possible. As well it would be desirable for expert career advisors to be employed in Cambodian high schools.

Finally, media such as radio, television programmes, newspapers, and magazines have potential to be good sources of information for students and their families. It is important to use public media to show study and career opportunities. Because only one participant mentioned public media as a source of information, it is likely that media is not yet being used effectively to reach students. The current research 
recommends that the Cambodian government work with media agencies to provide accurate information to students related to the labour market.

\section{Areas for further research}

As a qualitative study, numerous factors were identified in this study that would not have emerged with a strictly quantitative approach, but additional quantitative work would much more clearly identify the contribution of variables to motivational factors. Follow-up studies would be helpful in this area.

The current study adapted the expectancy-value theory in understanding students' motivation to choose a business major in Cambodia. Future research can explore students' motivation to choose a major in different cultural contexts using various motivational theories. Because most of the motivation theories were formed in Western culture, it is worth studying how these theories are applied in other cultural contexts. Further research could also look at more specific areas in the choice of career or major such as the influence of culture on the choice of major, gender differences in the choice of majors in Cambodian higher education, quality of higher education and the choice of major, with and without career guidance, and the cooperation between high schools and universities.

\section{Conclusions}

The current study found the expectancy and value beliefs of the expectancy-value theory as main factors in students' choice of major. The most important belief was the utility value, for example students expected that the business major would provide worthwhile employment. Interest and attainment values were important for many students in choosing a major that they liked and fitted their abilities (e.g. maths skills). Cost was considered as a challenge for students to undertake a degree, which required them to move away.

Added to foci on relationship between expectancy-value beliefs and the choice of a business major, the current study provided a broader understanding of sources of relevant to a choice of major. The most important influencers on students' choice were siblings and relatives who had a high level of education. Parents were usually the 
financial supporters. Friends were the main source of information on the major and high school teachers were advisors who provided feedback on the choice.

The study provided further understanding of the influence of culture on Cambodian students' choice of a major. Family members were heavily involved in the decisionmaking process. The choice was more one made by the family, rather than an individual. Students expected to support their families after they became employed. Most of the students did not want to move away from their families because they had never lived on their own and their families believed that living away was not a safe option.

The current study provided a number of recommendations to key stakeholders including Cambodian policy makers, ACC, universities, high schools, high school teachers, parents, and other relevant agents. The recommendations were mainly to support a student's decision-making process, as it is not only important for students and their families, but also for the country's development. The current study expects that strong collaboration among the stakeholders will lead to good choices of majors and these choices will lead to higher employment rates and also the fulfillment of the social needs of development. 


\section{References}

Anderman, E. M., \& Patrick, H. (2012). Achievement goal theory, conceptualization of ability/intelligence, and classroom climate. In S. L. Christensen, A. L. Reschly \& C. Wylie (Eds.), Handbook of research on student engagement (Vol. XXVII, pp. 173191). New York: Springer

Armstrong, P. I., \& Vogel, D. L. (2010). Theoretical and methodological issues with testing the SCCT and RIASEC Models: Comment on Lent, Sheu, and Brown (2010) and Lubinski (2010). Journal of Counseling Psychology, 57(2), 239-247.

Bandura, A. (1977). Self-efficacy: Toward a unifying theory of behavioural change. Psychological Review, 84(2), 191-215.

Bandura, A. (1986). Social foundations of thought and action: A social cognitive theory. Englewood Cliffs, NJ: Prentice-Hall.

Bandura, A., Barbaranelli, C., Vittorio, G. V., \& Pastorelli, C. (2001). Self-efficacy beliefs as shapers of children's aspirations and career trajectories. Child Development, 72(1), 187-206.

Begg, J. M., Bantham, J. H., \& Taylor, S. (2008). Distinguishing the factors influencing college students' choice of major. College Student Journal, 42(2), 381-394.

Berzin, S. C. (2010). Educational aspirations among low-income youths: Examining multiple conceptual models. Children and Schools, 32(2), 112-124.

Betz, N. E., \& Hackett, G. (2006). Career self-efficacy theory: Back to the future. Journal of Career Assessment, 14(1), 3-11.

Betz, N. E., Klein, K., \& Taylor, K. (1996). Evaluation of a short form of the career decision-making self-efficacy scale. Journal of Career Assessment, 4, 47-57.

Betz, N. E., \& Rottinghaus, P. J. (2006). Current research on parallel measures of interests and confidence for basic dimensions of vocational activity. Journal of Career Assessment, 14, 56-76. 
Boyd, S., \& MacDowall, S. (2003). Innovative pathways from secondary school: Gaining a sense of direction. Paper presented at the the 2003 NZARE/AARE Conference, Auckland.

Brennan, L. (2001). How prospective students choose universities: A buyer behaviour perspective. (Doctoral Thesis), University of Melbourne.

Brooks, R. (2004). My mum would be pleased as punch if I actually went, but my dad seems a bit more particular about it: Paternal involvement in young people's higher education choice. British Education Research Journal, 30(4), 495-515.

Brown, R. (2011). Higher education and the market: New York and London: Taylor \& Francis.

Burnard, P., Gill, P., Stewart, K., Treasure, E., \& Chadwick, B. (2008). Analysing and presenting qualitative data. British Dental Journal, 204(8), 429-433.

Cambodian Federation of Employers and Business Associations. (2008). Youth and employment: Bridging the gap. Phnom Penh: CAMFEBA.

Carnevale, A. P., Cheah, B., \& Strohl, J. (2011). Hard times, college majors, unemployment and earnings: Not all college degrees are created equal. Washington, D.C.: Georgetown University.

Cebula, R. J., \& Lopes, J. (1982). Determinants of student choice of undergraduate major field. American Educational Research Journal, 19(Summer), 303-312.

Chenoweth, E., \& Galliher, R. V. (2004). Factors influencing college aspirations of rural West Virginia high school students. Journal of Research in Rural Education, 19(2), 1-14.

Chet, C. (2006). Cambodia. Higher education in Southeast Asia. Bangkok, Thailand: UNESCO.

Chhim, S. H. (1987). Introduction to Cambodian culture. San Diego, CA: Multifunctional Resource Center.

Chillas, S. (2009). Degrees of fit? Matching in the graduate labour market. Employee Relations, 32(2), 156-170. 
Christie, H., Munro, M., \& Fisher, T. (2004). Leaving university early: Exploring the difference between continuing and non-continuing students. Studies in Higher Education, 29(5), 617-636.

Cohen, J., \& Hanno, D. M. (1993). An analysis of underlying constructs affecting the choice of accounting as a major. Issues in Accounting Education, 8(2), 219-219.

Connor, H., Dewson, S., Tylers, C., Eccles, J., Regan, J., \& Aston, J. (2001). Social class and higher education: Issues affecting decisions on participation by lower social class groups (pp. 1-130). Norwich: Institute for Employment Studies.

Creed, P. A., \& Yin, W. O. (2006). Reliability and validity of a Chinese version of the career decision-making difficulties questionnaire. International Journal of Educational and Vocational Guidance, 6(1), 47-63.

Crowley, K. (2010). Cambodian national education policy: Global wants and /or local needs? (Doctor of Philosophy Doctoral Thesis), The University of Western Ontario London, Ontario.

Dawson-Threat, J., \& Huba, M. E. (1996). Choice of major and clarity of purpose among college seniors as a function of gender, type of major, and sex-role identification. Journal of College Student Development, 37, 297-308.

Dudley, S. C., Dudley, L. W., Clark, F. L., \& Payne, S. (1995). New directions for the business curriculum. Journal of Education for Business, 70(5), 305-310.

Dweck, C. S., \& Leggett, E. L. (1988). A social cognitive approach to motivation and personality. Psychological Review, 95(2), 256-273.

Eccles, J. S. (2009). Who am I and what am I going to do with my life? Personal and collective identities as motivators of action. Educational Psychologist, 44(2), 78-89.

Eccles, J. S., \& Wigfield, A. (1995). In the mind of the actor: The structure of adolescents' achievement task values and expectancy-related beliefs. Personality and Social Psychology Bulletin, 21(3), 215-225.

Economic Institute of Cambodia. (2008). Cambodia's labor market and employment. Phnom Penh: The World Bank. 
Elliott, J. G., Hufton, N. R., Willis, W., \& Illushin, L. (2005). Motivation, engagement and educational performance: International perspectives on the contexts for learning. New York: Palgrave Macmillan.

Ford, D. (2006). Cambodian higher education: Growing pains. International Higher Education, 44, 10-11.

Freeman, R. B. (1975). Overinvestment in college training. The Journal of Human Resources, X:3(Summer), 287-311.

Galotti, K. M. (1999). Making a "major" real-life decision: College students choosing an academic major. Journal of Educational Psychology, 91(2), 379-387.

Giladi, K., Amoo, T., \& Friedman, H. H. (2001). A survey of accounting majors: Attitudes and opinions. The National Public Accountant, 46(2), 25-27.

Hesketh, B., \& Rounds, J. (1995). International cross-cultural approaches to career development. In W. B. Walsh \& S. H. Osipow (Eds.), Handbook of vocational psycholoy: Theory, research and practice (pp. 367-390). Mahwah: Erlbaum.

Ho, I. T., Hau, K. T., \& Salili, F. (2007). Expectancy and value as predictors of Chinese students' achievement goals. In F. Salili \& R. Hoosain (Eds.), Culture, motivation, and learning (pp. 69-90). Charlotte, NC: Information Age.

Hoffman, J. J., Goldsmith, E. B., \& Hofacker, C. F. (1992). The influence of parents on female business students' salary and work hour expectations. Journal of Employment Counselling, 29(2), 79-83.

Holland, J. L. (1973). Making vocational choice: A theory of careers Englewood Cliffs, NJ: Prentice-Hall.

Holland, J. L. (1997). Making vocational choices: A theory of vocational personalities and work environment. Odessa, FL: Psychological Assessment Resources.

Hossler, D., \& Gallagher, K. S. (1987). Studying student college choice: A three-phase model and the implications for policymakers. College and University, 62(3), 207-221.

HRINC. (2010). Higher education and skills for the labor market in Cambodia. Unpublished manuscript. World Bank. Phnom Penh. 
Hughes, C. (2011). The influence of self-concept, parenting style and individualismcollectivism on career maturity in Australia and Thailand. International Journal of Educational and Vocational Guidance, 11, 197-210.

Innes-Brown, M. (2006). Higher education, Cambodia. Australian Education International. Canberra: National Office of Overseas Skills Recognition.

Johnson, B., \& Christensen, L. (2008). Educational research: Quantitative, qualitative and mixed approaches (3rd ed.). Thousand Oaks, CA: Sage.

Jones, B. D., Paretti, M. C., Hein, S. F., \& Knott, T. W. (2010). An analysis of motivation constructs with first-year engineering students: Relationships among expectancies, values, achievement, and career plans. Journal of Engineering Education, 99(4), 319-336.

Keller, M. J., \& McKeow, M. P. (1984). Factors contributing to the postsecondary enrollment decisions of Maryland national merit and national achievement semifinalists. Paper presented at the annual meeting of the association for the study of higher education, Chicago, IL.

Kim, D., Markham, F. S., \& Cangelosi, J. D. (2002). Why students pursue the business degree: A comparison of business majors across universities. Journal of Education for Business, 78(1), 28-32.

Kim, U., \& Park, Y. S. (2006). Factors influencing academic achievement in collectivist societies: The role of self, relational, and social efficacy. In F. Pajares \& T. Urdan (Eds.), Self-efficacy beliefs of adolescents (pp. 267-286). Greenwich, CT: Information Age.

Koch, J. V. (1972). Student choice of undergraduate major field of study and private internal rates of return. Industrial and Labor Relations Review, 26(1), 680-685.

Kumar, R., \& Maehr, M. L. (2007). Cultural interpretations of achievement motivation. In F. Salili \& R. Hoosain (Eds.), Culture, motivation, and learning: $A$ multicultural perspective (pp. 43-66). USA: Information Age. 
Lackland, A. C., \& Lisi, R. D. (2001). Students' chioces of college majors that are gender traditional and nontraditional. Journal of College Student Development, 42(1), $39-48$.

Larson, M. L. (1984). Meaning-based translation: A guide to cross-language equivalence. Lanham, MD: University Press of America.

Leach, L., \& Zepke, N. (2005). Student decision-making by prospective tertiary students: A review of existing New Zealand and overseas literature. Report to Ministry of Education. New Zealand: Ministry of Education.

Lee, H., \& Rojewski, J. W. (2012). Development of occupational aspirations in early Korean adolescents: A multiple-group latent curve model analysis. International Journal of Educational and Vocational Guidance, 12, 189-210.

Lent, R. W. (2005). A social cognitive view of career development and counseling. In S. D. Brown \& R. W. Lent (Eds.), Career development and counseling: Putting theory and research to work (pp. 101-127). New York: John Wiley.

Lent, R. W., \& Brown, S. D. (1984). Relation of self-efficacy expectations to academic achievement and persistence. Journal of Counselling Psychology, 31(3), 356-362.

Lent, R. W., \& Brown, S. D. (1987). Comparison of three theoretically derived variables in predicting career and academic behavior: Self-efficacy, interest congruence and consequence thinking. Journal of Counseling Psychology, 34(3), 293298.

Lent, R. W., \& Brown, S. D. (2000). Contextual supports and barriers to career choice: A social cognitive analysis. Journal of Counseling Psychology, 47(1), 36-49.

Lent, R. W., \& Brown, S. D. (2006). On conceptualizing and assessing social cognitive constructs in career research: A measurement guide. Journal of Career Assessment, 14(1), 12-35.

Lent, R. W., Brown, S. D., \& Hackett, G. (1994). Toward a unifying social cognitive theory of career and academic interest, choice, and performance. Journal of Vocational Behavior, 45(1), 79-122. 
Lent, R. W., Brown, S. D., \& Hackett, G. (1996). Career development from a sociocognitive perspective. In D. Brown \& L. Brooks (Eds.), Career choice and development (3rd ed., pp. 373-422). San Francisco: Jossey-Bass.

Lent, R. W., Lopez, A. M., Lopez, F. G., \& Sheu, H. (2008). Social cognitive career theory and the prediction of interests and choice goals in the computing disciplines. Journal of Vocational Behavior, 73, 52-62.

Lent, R. W., Sheu, H., Singley, D., Schmidt, J. A., Schmidt, L. C., \& Gloster, C. S. (2008). Longitudinal relations of self-efficacy to outcome expectations, interests, and major choice goals in engineering students. Journal of Vocational Behavior, 73, 328335.

Leppel, K., Williams, M., \& Waldauer, C. (2001). The impact of parental occupation and socioeconomic status on choice of college major. Journal of Family and Economic Issues, 22(4), 373-394.

Lichtman, M. (2010). Qualitative research in education: A user's guide. San Francisco, CA: Sage.

Lysonski, S., \& Durvasula, S. (1998). A cross-sectional investigation of student attitudes toward personal selling: Implications for marketing education. Journal of Marketing Education, 2(2), 161-173.

Malgwi, C. A., Howe, M. A., \& Burnaby, P. A. (2005). Influences on students' choice of college major. Journal of Education for Business, 80(5), 275-282.

Matusovich, H. M., Streveler, R. A., \& Miller, R. L. (2010). Why do students choose engineering? A qualitative, longitudinal investigation of students' motivational values. Journal of Engineering Education, 99(4), 289-303.

Mau, W. C. (2000). Cultural differences in career decision-making styles and selfefficacy. Journal of Vocational Behavior, 57, 365-378.

Mau, W. C., \& Bikos, L. H. (2000). Educational and vocational aspirations of minority and female students: A longitudinal study. Journal of Counseling \& Development, $78(2), 186-194$. 
Mauldin, S., Crain, J., \& Mounce, P. (2000). The accounting principles instructor's influence on students' decision to major in accounting. Journal of Education for Business, 78, 153-157.

Maxwell, G., Cooper, M., \& Biggs, N. (2000). How people choose vocational education and training programs: Social, educational and personal influences on aspiration. Leabrook, Australia: National Centre for Vocational Education Research.

Mclnerney, C. R., Didonato, N., Giagnacova, R., \& O'Donnell, A. M. (2006). Students' choice of information technology majors and careers: A qualitative study. Information Technology, Learning, and Performance Journal, 24(2), 35-53.

McMillan, J. H. (2008). Educational research: Fundamentals for the consumer (5th ed.). Boston, MA: Pearson Education.

Merriam, S. B. (1988). Case study research in education. A qualitative approach. San Francisco, CA: Jossey-Bass.

Merriam, S. B. (2001). Qualitative research and case study applications in education: Revised and expanded from case study research in education (2nd ed.). San Francisco, CA: Jossey-Bass.

Merriam, S. B. (2002). Qualitative research in practice: Example for discussion and analysis. San Francisco, CA: Jossey-Bass.

Miles, M. B., \& Huberman, A. M. (1994). Qualitative data analysis: An expanded sourcebook. Thousand Oaks, CA: Sage.

Ming, J. S. K. (2010). Institutional factors influencing students' college choice decision in Malaysia: A conceptual framework. International Journal of Business and Social Science, 1(3), 53-58.

Ministry of Planning. (2008). General population census of Cambodia (Vol. 12). Phnom Penh: Author.

MoEYS. (2004). Policy for curriculum development 2005-2009. Phnom Penh: Author.

MoEYS. (2005). Education strategic plan 2006-2010. Phnom Penh: Author. 
MoEYS. (2009). National education congress report. Phnom Penh: Author.

MoEYS. (2011). Higher education in Cambodia. Phnom Penh: Author.

Montmarquette, C., Cannings, K., \& Mahseredjian, S. (2001). How do young people choose college majors? Economics and Education Review, 21, 543-556.

National Institute of Statistics. (2009). Cambodia socio-economic survey. Phnom Penh: Author.

New Zealand Association for Research in Education. (2010). Ethical Guidelines. Wellington: Author.

Ng, C. H., \& Renshaw, P. D. (2002). Self-schema, motivation and learning: A cross cultural comparison. In D. Mclnerney \& S. Van Etten (Eds.), Sociocultural influences on motivation and learning (Vol. 2, pp. 55-87). Greenwich, CT: IAP.

Nicholls, J. G. (1984). Achievement motivation: Conceptions of ability, subjective experience, task choice, and performance. Psychological Review, 84, 231-259.

Odin, J. K., \& Manicas, P. T. (2004). Globalization and higher education: University of Hawaii Press.

Ordovensky, J. F. (2004). The effects of race, sex, and expected returns on the choice of college major. Eastern Economic Journal, 30(4), 549-562.

Oyserman, D., Coon, H. M., \& Kemmelmeier, M. (2002). Rethinking individualism and collectivism: Evaluation of theoretical assumptions and meta-analyses. Psychological Bulletin, 128, 3-72.

Pajares, F. (2007). Culturalizing educational psychology. In F. Salili \& R. Hoosain (Eds.), Culture, motivation and learning: A multicultural perspective (pp. 19-42). Charlotte, NC: Information Age.

Patton, M. Q. (1987). How to use qualitative methods in evaluation. Newbury Park, CA: Sage. 
Pike, G. R. (2006). Students' personality types, intended majors, and college expectations: Further evidence concerning psychological and sociological interpretations of Holland's theory. Research in Higher Education, 47(7), 801-822.

Porter, S. R., \& Umbach, P. D. (2006). College major choice: An analysis of personenvironment fit. Research in Higher Education, 47(4), 429-449.

Pritchard, R. E., Potter, G. C., \& Saccucci, M. S. (2004). The selection of a business major: Elements influencing student choice and implications for outcomes assessment. Journal of Education for Business, 79(3), 152-156.

Rao, N., Moely, B. E., \& Sachs, J. (2000). Motivational beliefs, study strategies and mathematics attainment in high and low-achieving Chinese secondary school students. Contemporary Educational Psychology, 25, 287-316.

Sloper, D. (1999). Higher education in Cambodia: The social and educational context for reconstruction. Phnom Penh: UNESCO Principal Regional Office for Asia and the Pacific.

Song, C., \& Glick, J. E. (2004). College attendance and choice of college majors among Asian-American students. Social Science Quarterly, 85(5), 1401-1421.

St. John, E. (2000). Majors. Black Issues in Higher Education, 17(4), 21-27.

Super, D. E. (1980). A life-span, life-span approach to career development. Journal of Vocational Behavior, 16, 282-292.

Swanson, J. L., \& Tokar, D. M. (1991). College students' perceptions of barriers to career development. Journal of Vocational Behavior, 38(1), 92-106.

Swenson, M. J., Swinyard, W. R., Langrehr, F. W., \& Smith, S. M. (1993). The appeal of personal selling as a career: A decade later. Journal of Personal Selling and Sales Management, 13, 51-64.

Tan, Y. S. (2011). Democratization of secondary education in Malaysia: Attitudes towards schooling and educational aspirations. Asia Pacific Journal of Education, $31(1), 1-18$. 
Vallerand, R. J. (1997). Toward a hierachical model of intrisic and extrinsic motivation. Advances in Experimental Social Psychology, 29, 271-360.

Weber, E. U., Ames, D. R., \& Blais, A. R. (2004). "How do I choose thee? Let me count the ways"' A textual analysis of similarities and differences in modes of decision-making in China and the United States. Management and Organization Review, 1(1), 87-118.

Wigfield, A., \& Eccles, J. (1992). The development of achievement task values: A theoretical analysis. Developmental Review, 12(3), 265-310.

Wildman, M., \& Torres, R. M. (2001). Factors identified when selecting a major in agriculture. Journal of Agricultural Education, 42(2), 46-55.

World Bank. (2010). Providing skills for equity and growth: Preparing Cambodia's youth for the labor market. (Report No. 59989). Washington, DC: The International Bank for Reconstruction and Development.

World Bank. (2012). Matching aspirations: Skills for implementing Cambodia's growth strategy. (Report No. 67349). Phnom Penh: Author.

Yu, B., \& Fan, S. (2011). Rice production response in Cambodia. Agricultural Economics, 42, 437-450. 


\section{Appendices}

\section{Appendix A: Interview questions}

Adapted from the question list of Matusovich et al. (2010)

1. Can you tell me how you became interested in finance and banking?

a. Probe: personal, family, community

2. Have you ever considered other majors besides finance and banking?
a. If yes, what were these majors?
b. How was the decision for you to study finance and banking made?

3. Think of other business students that you have met here. Would you say that in general they are different from you or similar?

4. Think about your lecturers here at UBB. What would you say they think it means to be a good finance and banking officer?
a. How does that fit with your own image of a good finance and banking officer?

5. Okay, let's imagine it's a few years from now, and you've graduated with a degree in finance and banking.
a. What's next for you? (If not finance and banking, explore why they have made this choice)
b. What do you imagine yourself doing on a day-to-day basis?
c. What would you say it takes to be a good (insert student's career choice)? 


\section{Appendix B: Brief biographies of research participants}

\section{Mony}

Mony is a 21-year-old male who is doing the first year of a degree in finance and banking at UBB. He is from a suburb of Battambang. His father is a soldier and his mother is a farmer. He chose finance and banking because he liked it the most and it will contribute to achieving his goal. He likes subjects with numbers like maths, chemistry, and physics. His teacher, mother and father's friend supported his decision while his father wanted him to do law. He expects to get a job after he graduates as recommended by his father's friend. He considered the broad labour market within ASEAN countries in the future. However, he is worried about high competition in the labour market. He believes that working in the banking sector will help develop his country.

He also considered some other subjects such as English literature and law, which were recommended by his dad. He chose not to study law because he does not like rote learning. He had studied English literature in one university for one year because he received a scholarship in that major. However, finance and banking is his favourite major. He plans to get a job at a bank at some point in the near future. Currently, he has has three part-time jobs to support his study. He has three major plans (1) to get a position in a bank, (2) to become involved in politics and (3) to starta family.

\section{Chamnab}

Chamnab is 20 years old from a suburb of Battambang. His farther is a farmer and his mother is a vendor. He has seven siblings and his parents have to support all of them during their education. He chose finance and banking because he believes that the banking sector is booming and there will be more investment in the country in this sector. He discussed his choice with his friends and family.

He went to tourism class for a week because his girlfriend was there. He quit because he was not learning well and he was not interested in tourism. He thought that working in tourism may require travelling a lot and he does not want to live away from his family. He was interested in English literature but he did not choose it because his English is not good and he doesn't want to become a teacher. Moreover, he is able to learn maths more easily than literature. He was also interested in IT but thought that IT 
has a smaller labour market and it would be better to learn IT in Phnom Penh, for which the cost would have been prohibitive. He wants to work for a bank. He loves this job because it is not hard and it provides a good salary and social status. His longer-term plan is to run his own business. He intends to start working at a bank and then save for his own business.

\section{Sophy}

Sophy is 19 years old from a province, which is distant from Battambang and closer to Phnom Penh. She did not go to Phnom Penh because she has no relatives there. She chose finance and banking because she believed that Cambodia and its banking sector are developing. She got this information from her uncle who is working for a local bank. Some of her high school teachers talked about the labour market, too. Her parents allowed her to make her own decision. Her relatives and neighbours supportedher choice. She was also interested in becoming a medical doctor but this major requires a lot of money and her family could not afford it. Some of her relatives asked her to choose marketing but she did not like it. She expects to get a job at a bank. She likes wearing beautiful uniforms and working in an air-conditioned room even though the salary is not very high. She plans to work in Battambang. She believes that it would have been hard for her, as a girl, to study and work far away from her family, but her parents would have supported her.

\section{Mara}

Mara is 24 years old and comes from the outskirts of Battambang. His parents are farmers. He won a scholarship to learn management at a local institute. He had been learning there for three years until the institute went bankrupt. He could not get his study record so he had to start his new major from the first year at UBB. He decided to choose finance and banking because he discussed it with his elder sister and both of them agreed that he should major in finance and banking to get a job and save up for his own business in the future. They thought that if he learned management, he would not be able to manage a business yet because they wouldnot have enough money. Mara also thought that management was hard to study. He was also interested in marketing, tourism, and accounting. He likes finance and banking the most and he also likes maths. Some friends of his asked him to change his major to law but he rejected this becausehe doesnot like having to learn information by heart. His decision was made 
following discussions with his elder sister and high school teachers. Mara is now working part time to have an income and experience for his future business. He is also improving his English skills and self-confidence, which he believes are important for this success.

\section{Boeb}

Boeb is 22 years old. He has eight siblings. His father has passed away and his mother stays at home. His elder sister is the breadwinner of the family. Boeb has the highest education in his family. He firstly became interested in finance and banking when he read an English book about a bank manager. When he made his decision, he discussed it with friends, his aunt who is a treasurer, his sister, and brother-in law who works for a private company. All of them supported him to do this degree. He was interested in law too. However, if he learns law, he had better learn it in Phnom Penh where cost is higher. He also likes English literature and veterinary science. He may choose it as a sub-major. He would like to be a financial officer when he graduates and he will work hard to become promoted to the role of bank manager. He thinks that to be a good bank worker, he needs to be punctual, have good morality, and also respect the internal discipline. He is improving his English and computer skills to compete in the job market, and he is worried about competition. He thinks besides capacity and characters, networking is an important factor inobtaining a job. Knowing someone who is working for a bank, is better than knowing no one.

\section{Navy}

Navy is 18 years oldfrom Battambang town. Her father works at a railway station and her mother stays at home. She chose finance and banking because she thinks that there will be more banks and micro-finance institutes in the future. She expects to get a good job after she graduates. She likes working in an office and she likes maths. She discussed her choices with her parents. She was also interested in law. She learned law for a month in Phnom Penh but she dropped out because her family could not support this high expense. She decided to do finance and banking because she has some relatives who are working for banks. However, she plans to change her major to accounting in her second year. She discussed this idea with her uncle who is doing the fourth year of a degree in finance and banking. Both of them agreed that if she learns accounting, she would be able to work in either a bank or a company. She also 
discussed this change with her parents and high school teacher. They allowed her to choose what she really likes. In the future she wants to be an accountant and get a good salary to support her family. She believes that she needs good knowledge, experience, and honesty to be a good accountant. She needs to study hard and seek more work experience prior to applying for a permanent job. She is improving her French and English skills. She would like the government to create more job opportunities and for the university to cooperate with more banks and companies at which students could volunteerand gain experience during their degrees.

\section{Sam}

Sam is 19 years old from a neighbouring province to Battambang province. His parents are farmers. He has four siblings. He chose between two majors before his enrolment: finance and banking, and tourism. He discussed the choices with his family, friend, and his uncle who works at a bank. He chose it because he wants to wear a nice uniform. He also thinks this major is not hard to learn. Sam chose not to do law because he thinks that he is not good at learning by heart and his writing skills are not good. He also thinks that it would be hard to get a job if he learnt law. He has never been interested in agriculture because he prefers office work. He believes he needs to improve his computer, maths, and customer service skills in order to get a job at a bank. He plans to apply for a job when he gets into his second year. He also plans to run his own business after he saves up enough money from his job.

\section{Sokha}

Sokha is 22 years old and from one of the largest rice production districts of Battambang. Her parents are farmers. She won a scholarship from a non-governmental organization, which covers her school fees and computer training courses. She has been interested in finance and banking since she was in grade 10 at high school, because she likes office work and nice uniforms. Her family, including her grandparents and parents, supports her choice. She believes that she needs language skills, maths, and general knowledge to compete for a job. She is improving her English skills. After she graduates, her family will support her to pursue a master's degree. She is working part time as an accountant. She is on track to reach her goal. The scholarship donor will support her in finding a job during the university holidays. 


\section{Phally}

Phally is 20 years old. She is from a district about 40 kilometres from Battambang town. She is interested in finance and banking because she expects to get a good job and she is interested in learning about finance and banking. Before she made her decision, she discussed the choice with her sisters. She was also interested in accounting and management. She followed her elder sisters' suggestion. Her sisters believed that finance and banking would provide a larger job market compared to accounting and management. They also believed that there would be more banks in the future. After her graduation, she plans to work for a bank or a company. She will start to apply for a job when she is in her second year. She is not very confident to get a job, though. She thinks she needs to improve her English and computer skills. After she has saved enough money, she will run her own business.

\section{Chea}

Chea is 19 years old. She is from Battambang town. Both of her parents work for nongovernmental organizations. She chose finance and banking because she likes financial-related tasks. She thinks that the labour market will be large, despite higher job competition following the free flow of labour, within ASEAN countries in 2015. Her decision involved her parents, grandparents, friends, and high school teacher. The first step she tookwas to list advantages and disadvantages of each choice. Her choices were accounting, tourism, and finance and banking. Then she discussed her lists with her family and friends again. She considered her choice again after she talked to bank staff who did not recommend finance and banking. She did not change her major because she did not want to waste her time. Her choice at that time was dependant on projected job opportunities. Her actual interest is jewellery design. She did not major in it because this major was only available in Phnom Penh. She does not want to live away from her family and she does not want to spend her family's money. She decided to learn finance and banking to get a job and save money. Her next plan is to support herself to learn jewellery design and run a small business. Her parents are not supporting her to create a small business: an Internet shop. She is improving her knowledge and skills such as English, Chinese, and computer skills. She believes that if she has these skills, she will be able to compete for a good job. 


\title{
Appendix C: Information sheets
}

\section{Information sheets for Ministry of Education, Youth and Sports of Cambodia}

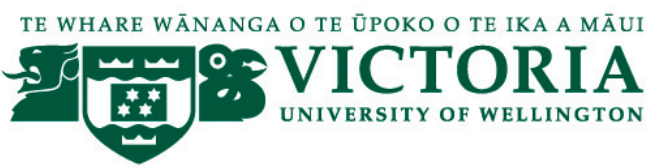

\section{Faculty of Education}

05 June 2012

\author{
Ministry of Education, Youth, and Sports \\ Phnom Penh \\ Cambodia
}

Dear Sir/Madame,

\section{Re: Students' Choice of Business Majors and Careers: A Qualitative Case Study of Motivation to Study Finance and Banking}

My name is Sokalyan Mao. I am currently on study leave from my position as a lecturer at the University of Battambang. I am completing a Master of Education at Victoria University of Wellington. My research study aims to develop an indepth understanding of how and why students choose to major in a business degree and to explore students' perceptions of their future careers. I am writing to request your permission to conduct my research at the University of Battambang.

I hope the research will make a valuable contribution by providing insights into how students choose their major, specifically how students' value beliefs contribute to their major choice, and about what students think about their future careers. It may 
help the Ministry in developing policy and initiatives which can support students to be ready for a competitive job market.

This research will not damage the reputation of the university nor of Cambodian education. The focus is on students major and career choice and not on the practices of the university.

I would like to interview eight to ten first-year students enrolled in finance and banking during the academic year of 2011-2012 at the University of Battambang. Each interview will last between 60 and 90 minutes. I would arrange a presentation to introduce my research study to the first-year finance and banking classes. This presentation would inform students about the research and seek their voluntary and informed consent. All interviews with students would be arranged at any time convenient for the university and students and to be least disruptive for the classes. I would appreciate being able to meet with the students again for a focus group discussion at the end of the project. This focus group discussion would be to seek the students' feedback on the emergent findings of the study.

Student participants will not be named nor will they be identifiable in the thesis or other reports from the research. I will ensure that their personal information is kept confidential. Informed consent will be obtained through a signed consent form. Students would be able to withdraw from participation until a week after their interview without having to explain.

Access to the research data will be restricted to my supervisor, Dr. Stephanie Doyle, and me. All responses will be kept in password-protected computer files or locked offices at Victoria University of Wellington and will be destroyed five years after the conclusion of the research. The research has been approved by the Victoria 
University of Wellington's Faculty of Education Ethics Committee. Once my thesis is completed, it will be deposited in the University of Battambang and Victoria University of Wellington's libraries and a copy sent to Cambodia Ministry of Education, Youth, and Sports.

If you would like to receive more information regarding my research, please do not hesitate to contact my supervisor at the below address:

Dr. Stephanie Doyle

Senior Lecturer

School of Educational Psychology and Pedagogy

Victoria University of Wellington

Wellington 6012, New Zealand

DDI: +644 4636657

stephanie.doyle@vuw.ac.nz

Or you could contact me directly at:

Sokalyan Mao

Faculty of Education

Victoria University of Wellington

maosoka@myvuw.ac.nz

Yours faithfully,

Sokalyan Mao 


\title{
2. Information sheets for the rector of the University of Battambang
}

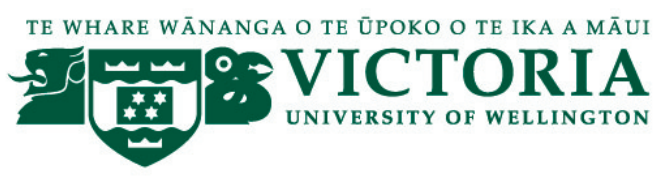

\section{Faculty of Education}

05 June 2012

\author{
H.E. Dr. Touch Visal Sok \\ President \\ University of Battambang \\ Sangkat Prek Preah Sdach \\ Battambang, Cambodia \\ Your Excellency,
}

\section{Re: Students' Choice of Business Majors and Careers: A Qualitative Case Study of Motivation to Study Finance and Banking}

My name is Sokalyan Mao. I am currently on study leave from my position as a lecturer at the University of Battambang.I am completing a Masterof Education at Victoria University of Wellington. My research study aims to develop an indepth understanding of how and why students choose to major in a business degree and to explore students' perceptions of their future careers.

I hope the research will make a valuable contribution by providing insights into how students choose their major, specifically how students' value beliefs contribute to their major choice, and about what students think about their future careers. These findings may help the university in designing effective recruitment and guidance programmes which can support students to be ready for a competitive job market.

Thisresearch will not damage the reputation of the university nor of Cambodian education. The focus is on students' major and career choice and not on the practices of the university.

I am writing to request your permission to invite ten of your students to engage in the research. I would like to interview eight to ten first-year students who are enrolled in finance and banking in the academic year of 2011-2012. Each interview will last between 60 and 90 minutes. All interviews with students would be arranged at any time which is convenient for the university and least disruptive for the classes. I would like your permission to arrange through the faculty for a presentation of my research study to the target classes. This presentation would inform students about the research and seek volunteers.

Following the interviews, I would appreciate being able to meet with the students again for a focus group discussion. This focus group discussion is to obtain feedback on the emergent findings. The data will be used in my thesis, and possibly in journal articles or conference presentations. Student participants will not be identifiable, and their personal information will be confidential. Informed consent will be obtained through a signed consent form. Students would be able to withdraw their participation until a week after their interview without having to give reasons. Access to the research data will be restricted to my supervisor, Dr Stephanie Doyle, and me. All 
responses will be kept in password-protected computer files and locked offices at Victoria University of Wellington and will be destroyed five years after the conclusion of the research. The research has been approved by the Victoria University of Wellington's Faculty of Education Ethics Committee. Once my thesis is completed, it will be deposited in the University of Battambang and Victoria University of Wellington's libraries and a copy sent to Cambodia Ministry of Education, Youth, and Sports.

If you would like to receive more information regarding my research, please do not hesitate to contact my supervisor at the below address:

Dr Stephanie Doyle

Senior Lecturer

School of Educational Psychology and Pedagogy

Victoria University of Wellington

Wellington 6012, New Zealand

DD: +6444636657

stephanie.doyle@vuw.ac.nz

Or you could contact me directly at:

Sokalyan Mao

Faculty of Education

Victoria University of Wellington

maosoka@myvuw.ac.nz

If you have any concerns about the research, you may contact:

Dr Allison Kirkman

Chairperson of the Human Ethics Committee

DDI: +644 4635676

allison.kirkman@vuw.ac.nz

Please accept, Your Excellency, the assurances of my highest consideration.

Yours sincerely,

Sokalyan Mao 


\title{
3. English version of information sheet for student participants
}

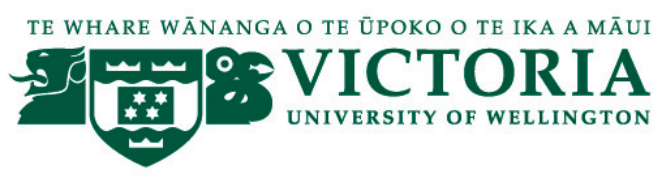

\author{
Faculty of Education
}

\section{Dear student
Re: Students' Choice of Business Majors and Careers: A Qualitative Case Study of Motivation to Study Finance and Banking

My name is Sokalyan Mao and I am currently on study leave from my position as a lecturer at Battambang University. I am doing a Master of Education at the Victoria University of Wellington. I am researching about how and why students choose to major in a business degree and exploring students' perceptions of their future careers. The research aims to interview eight to ten first-year students enrolled in finance and banking at the University of Battambang. This research has been assessed and approved by Victoria University of Wellington's Faculty of Education Ethics Committee.

\section{Would you like to take part in the research?}

I invite you take part in an interview about how you chose your major and your perception of your future career. If you decide to participate in the research but then you change your mind you can just withdraw your participation with me without having to explain the reason until a week after the interview.

\section{What would be involved?}

I would interview you at a place and time arranged by the university. The university and I will ensure that the interview would not distract you from your lecture.All interviews would be arranged at any time convenient for the university and students and to be least disruptive for the classes. Each interview would be audio-recorded and would last between 60 and 90 minutes. The interview will be conducted in Khmer language. The interviews will later be transcribed and you will have the opportunity to check your transcript. Once the 8-10 interviews have been completed I will arrange with the university to conduct a group discussion. The discussion is to seek participants' views on the emergent findings. Your feedback will be highly valued. I hope that you would find the interview and group discussion interesting and they might help you think about your own identity and future career plan.

\section{What would be confidential?}

Neither your name nor any information that would identify you will appear in the research reports. I will ensure that your personal information is confidential. All responses will be kept in password-protected files and locked offices at Victoria University of Wellington and will be destroyed five years after the completion of the research. My thesis reporting on the research will be deposited in the University of Battambang and Victoria University of Wellington's libraries and sent to Cambodia Ministry of Education, Youth, and Sports. 
A summary of the research findings will be made available upon your requests after the completion of this project. If you would like to receive more information regarding my research, please feel free to contact my supervisor at the below address:

Dr Stephanie Doyle

Senior Lecturer

School of Educational Psychology and Pedagogy

Victoria University of Wellington

Wellington 6012, New Zealand

DDI: +644 4636657

stephanie.doyle@vuw.ac.nz

Or you could contact me directly at:

Sokalyan Mao

Faculty of Education

Victoria University of Wellington

maosoka@myvuw.ac.nz

If you have any concerns about the research, you may contact:

Dr Allison Kirkman

Chairperson of the Human Ethics Committee

DDI: +644 4635676

allison.kirkman@vuw.ac.nz

Yours faithfully,

Sokalyan Mao 


\section{Khmer versions of information sheets for student participants}

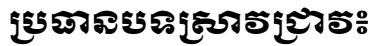

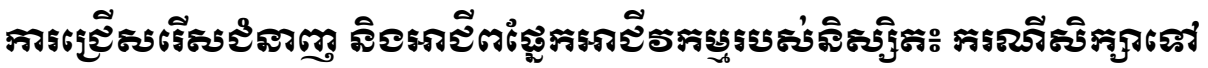

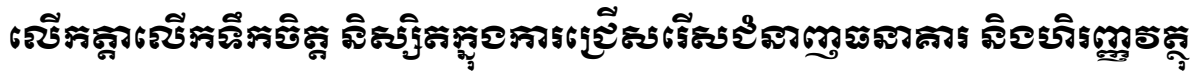

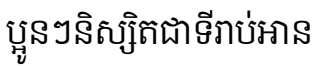

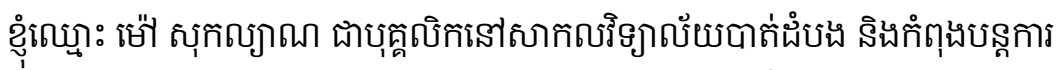

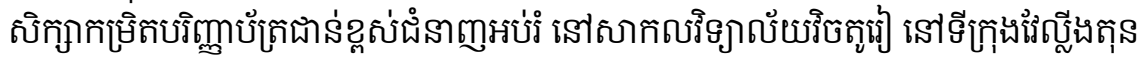

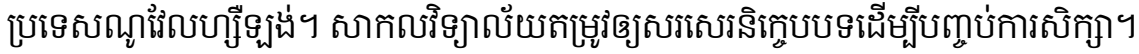

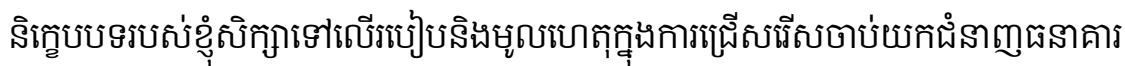

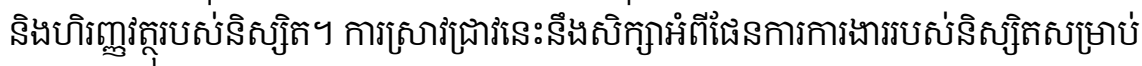

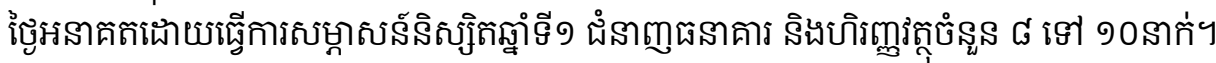

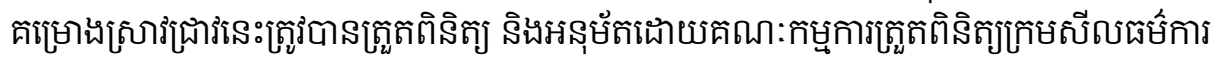

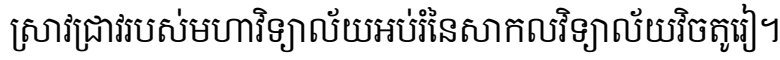

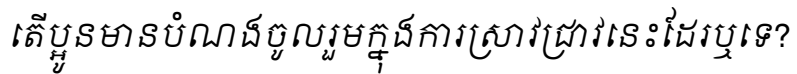

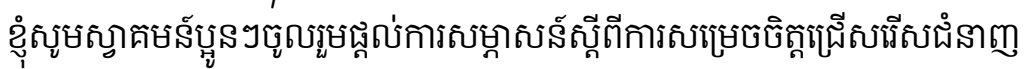

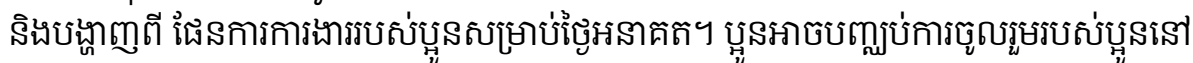

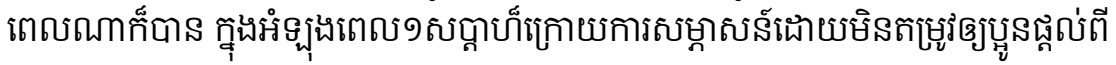

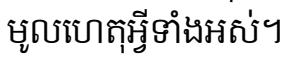

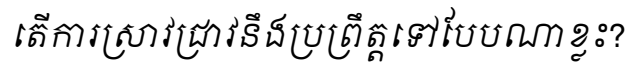

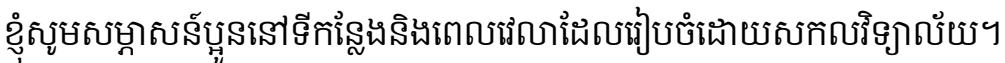

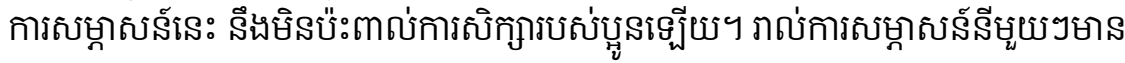

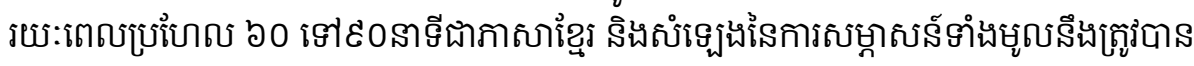

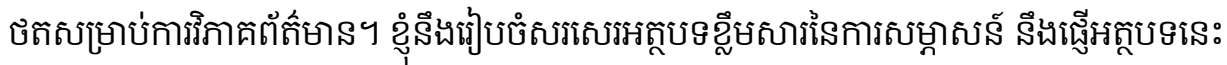

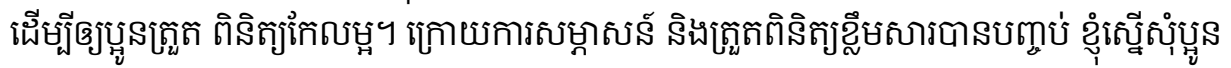

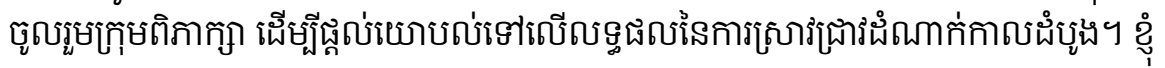

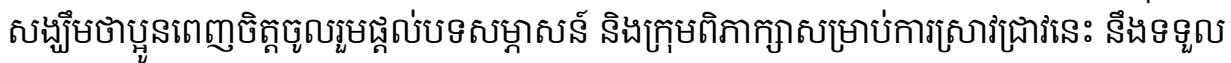

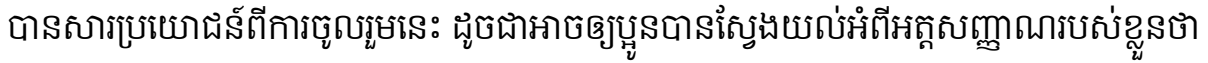




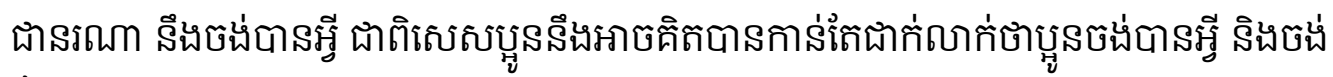

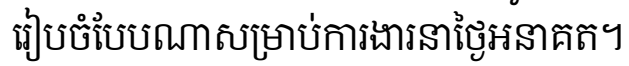

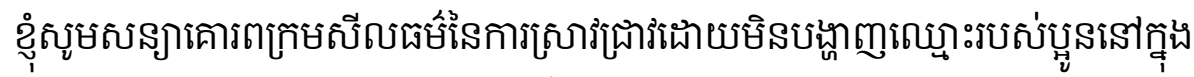

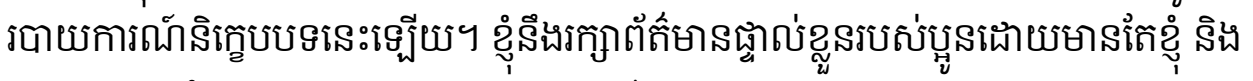

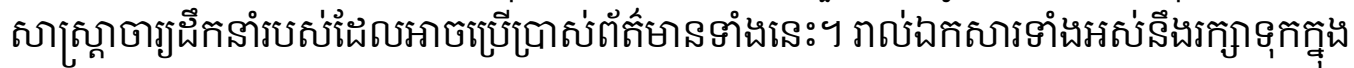

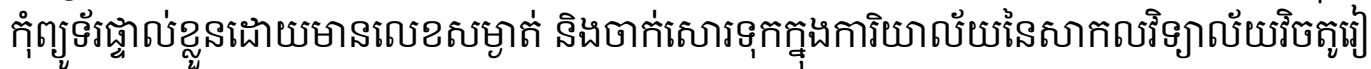

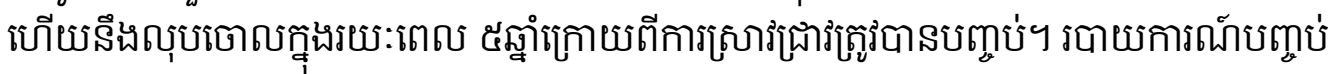

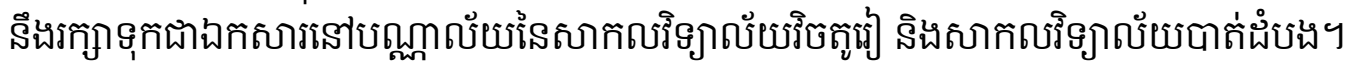

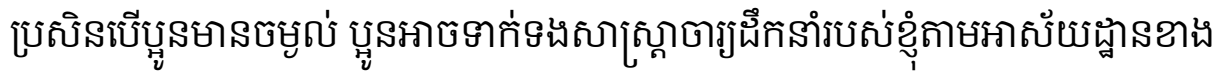
กโกายะ

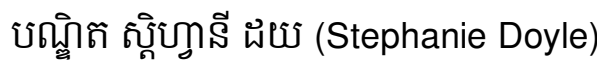

ถาโถูกตาย

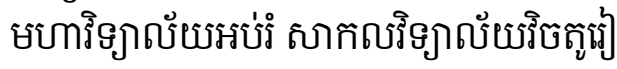

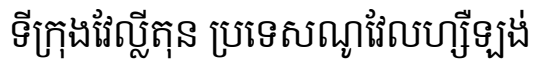

รู่ธัตูะ +644 4636657

รีุุิเยญ: Stephanie.doyle@vuw.ac.nz

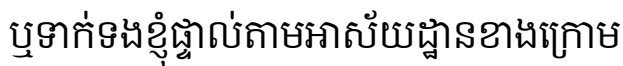

เชี่ ธุกิกญกภณก

รูรธัตัฒะ +85517227527

รีุุีนิญถ maosokalyan@gmail.com

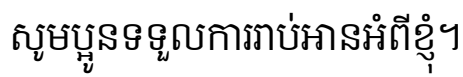

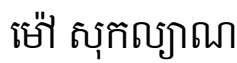




\section{Appendix D: Consent forms of the research}

1. Consent form for the rector of the University of Battambang

TE WHARE WĀNANGA O TE ŪPOKO O TE IKA A MĀU 59 ** $[\because$ university of Wellington

Students' Choice of Business Majors and Careers: A qualitative case study of motivation to study finance and banking

President Consent Form (Research)

\begin{tabular}{|l|l|}
\hline & $\begin{array}{c}\text { Please tick if you } \\
\text { agree }\end{array}$ \\
\hline $\begin{array}{l}\text { I consent to Sokalyan Mao conducting her research study as } \\
\text { outlined at the University of Battambang. }\end{array}$ & \\
\hline $\begin{array}{l}\text { I consent to the University of Battambang being identified in } \\
\text { the thesis and any other scholarly papers based on the } \\
\text { research. }\end{array}$ & \\
\hline I would like to receive a copy of the final thesis. & \\
\hline I consent to students being invited to be part of the research. & \\
\hline
\end{tabular}

Name:

Signed:

Date: 


\section{Consent form for student participants}

\section{Students' Choice of Business Majors and Careers: A qualitative case study of motivation to study finance and banking}

\section{Student Consent Form (Research)}

\begin{tabular}{|l|l|}
\hline & $\begin{array}{c}\text { Please tick if you } \\
\text { agree }\end{array}$ \\
\hline $\begin{array}{l}\text { I have had the research about students' choice of business majors and } \\
\text { careers explained, and my questions answered to my satisfaction. }\end{array}$ & \\
\hline I understand what would be required of me as a participant. & \\
\hline $\begin{array}{l}\text { I understand that being interviewed is voluntary and I can withdraw } \\
\text { from the project up until a week after the interview without having to } \\
\text { give reasons or without penalty of any sort. }\end{array}$ & \\
\hline $\begin{array}{l}\text { I understand that the interview and the focus group discussion will be } \\
\text { recorded and transcribed. }\end{array}$ & \\
\hline $\begin{array}{l}\text { I understand that I will have an opportunity to check the transcripts of } \\
\text { the interview before the analysis. }\end{array}$ & \\
\hline $\begin{array}{l}\text { I understand that I will not be identified in the thesis or any other } \\
\text { scholarly papers based on the research. }\end{array}$ & \\
\hline $\begin{array}{l}\text { I understand that the tapes of the interviews will be erased when the } \\
\text { thesis is submitted to the library, and that the transcript of the } \\
\text { interview would be stored safely and destroyed 5 years after the } \\
\text { completion of the research. }\end{array}$ & \\
\hline $\begin{array}{l}\text { I understand that the data from the project may be used in papers or } \\
\text { presentations that are concerned with students' choice of majors and } \\
\text { careers. }\end{array}$ & \\
\hline $\begin{array}{l}\text { I would like to receive a summary of the results of this research when } \\
\text { it is completed. }\end{array}$ & \\
\hline I consent to being interviewed. & \\
\hline
\end{tabular}

Name:

Email: (For copy of the summary)

Signed: Date: 


\section{Khmer version of consent form for student participants}

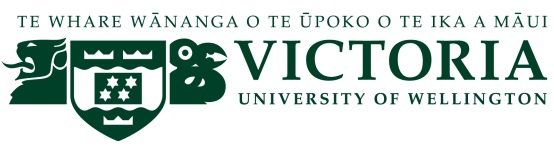

Faculty of Education

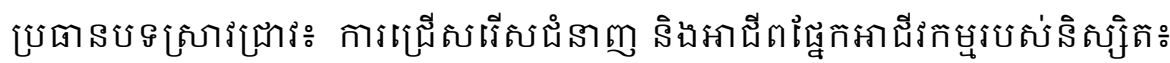

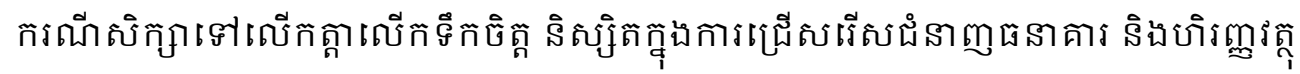

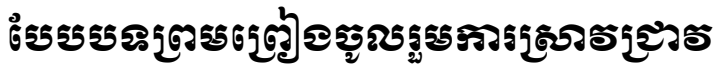 \\ Student Consent Form (Research)}

\begin{tabular}{|c|c|}
\hline & 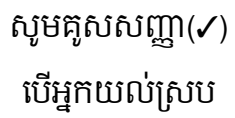 \\
\hline 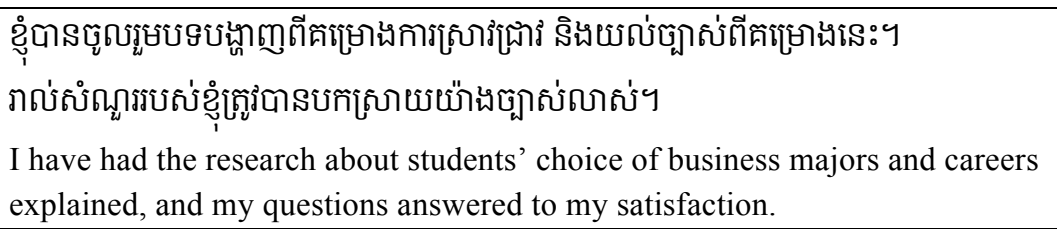 & \\
\hline 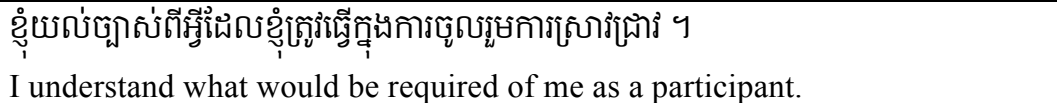 & \\
\hline 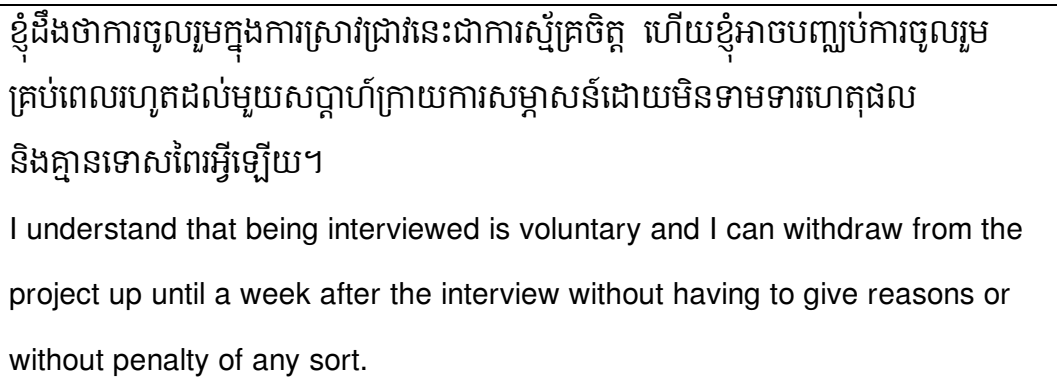 & \\
\hline 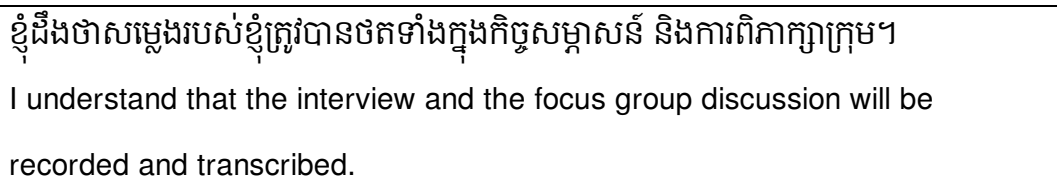 & \\
\hline 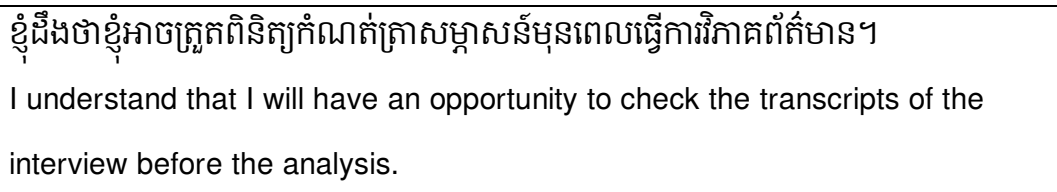 & \\
\hline 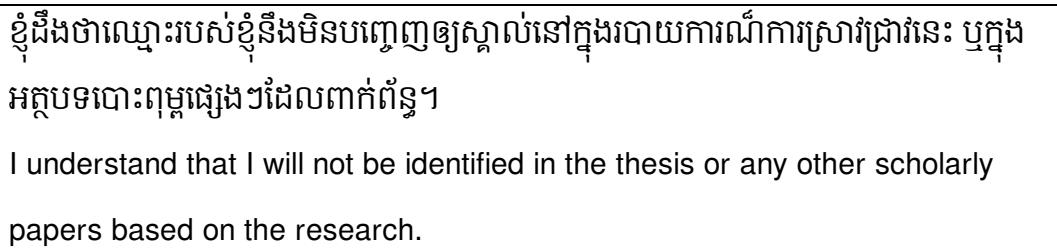 & \\
\hline
\end{tabular}




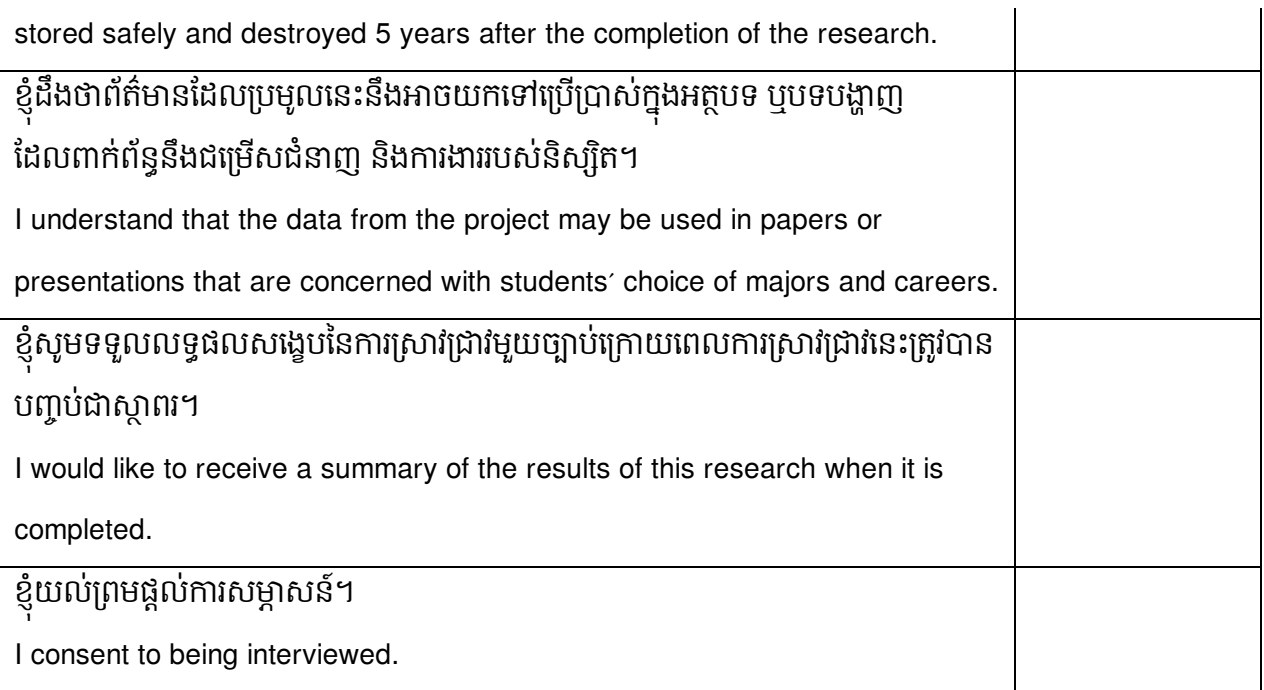

โญิฺุ $:$ (Name):

รุรุโิธิญ (Email): (For copy of the summary)

บกตุิโญชา (Signed):

กิญบิริโตู้ (Date): 